Portland State University

PDXScholar

Summer 8-21-2018

\title{
The Impact of Leader Race and Gender on Perceptions of Organizations in Response to Corporate Error
}

Nicolas Derek Brown

Portland State University

Follow this and additional works at: https://pdxscholar.library.pdx.edu/open_access_etds

Part of the Psychology Commons

Let us know how access to this document benefits you.

\section{Recommended Citation}

Brown, Nicolas Derek, "The Impact of Leader Race and Gender on Perceptions of Organizations in Response to Corporate Error" (2018). Dissertations and Theses. Paper 4545.

https://doi.org/10.15760/etd.6430

This Thesis is brought to you for free and open access. It has been accepted for inclusion in Dissertations and Theses by an authorized administrator of PDXScholar. Please contact us if we can make this document more accessible: pdxscholar@pdx.edu. 
The Impact of Leader Race and Gender on Perceptions of

Organizations in Response to Corporate Error

by

Nicolas Derek Brown

A thesis submitted in partial fulfillment of the requirements for the degree of

Master of Science

in

Psychology

Thesis Committee:

Larry R. Martinez, Chair

Leslie B. Hammer

Tessa L. Dover

Portland State University

2018 


\begin{abstract}
Prior research has demonstrated that CEO behavior influences how people perceive corporations and that CEOs associated with controversy can damage corporate reputations. Research also illustrates that attitudes based on prescribed racial and gender characteristics render Black and female CEOs as incongruent with leadership positions. The purpose of this study is to examine the impact of two different corporate errors as justification factors leading to prejudicial evaluations of leaders with stigmatized identities (e.g., race and gender), with a particular emphasis on the intersection of race and gender on leader- and organization-based evaluations. Participants were randomly assigned to one of 12 corporate conditions ([CEO race: white v. black] x [CEO gender: male v. female] x [Corporate error: no error v. diversity error v. non-diversity error]) and assessed to provide responses via an online experiment. Although results revealed a significant main effect of corporate error on leader and organization perceptions, there was no evidence of an interactive effect of CEO race and gender on leader and organization perceptions. Furthermore, the non-significant interaction of race and gender was not impacted by the context of the corporate error. I discuss theoretical and practical implications, study limitations, and avenues for future research.
\end{abstract}




\section{Table of Contents}

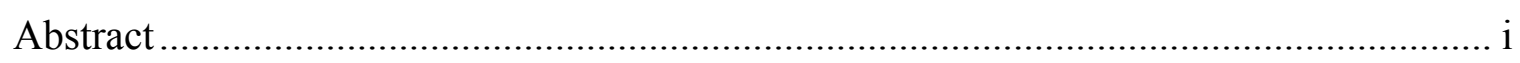

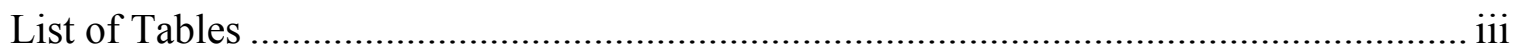

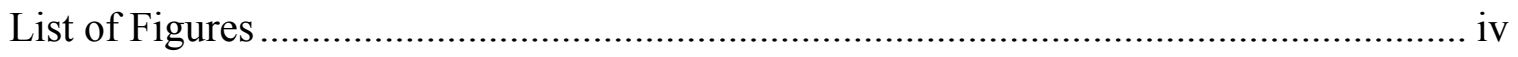

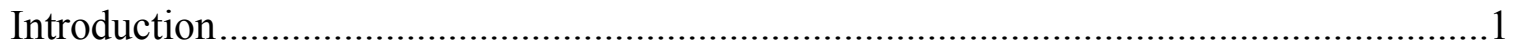

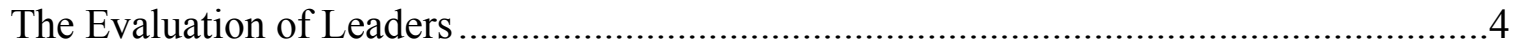

Inference-based Processing: The Impact of Causal Attributions on Perceived

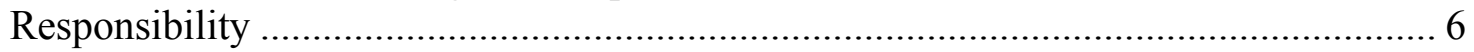

Recognition-based Processing: The Intersection of Race and Gender .......................... 9

The Justification of Prejudice towards Stigmatized CEOs ................................................13

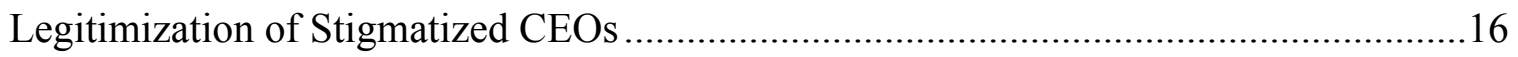

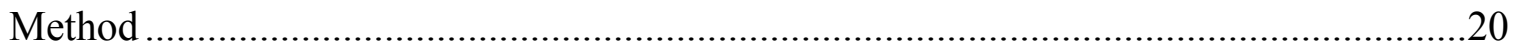

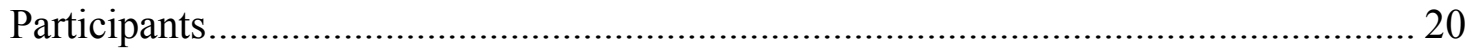

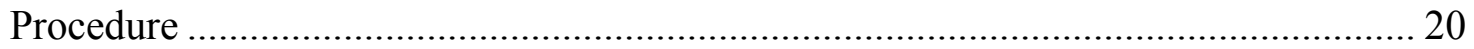

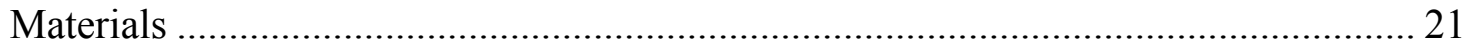

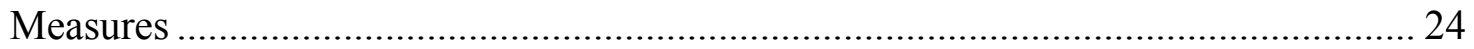

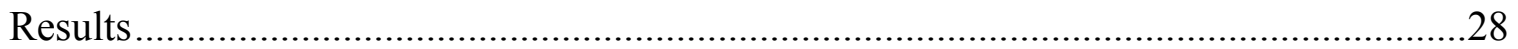

Main Effect of Error on Perceptions of the Leader.................................................. 29

Main Effect of Error on Perceptions of the Organization.............................................. 30

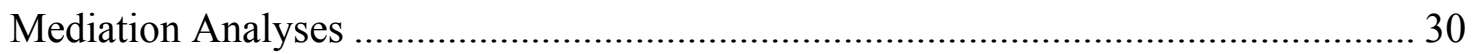

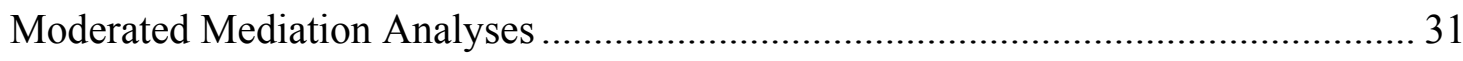

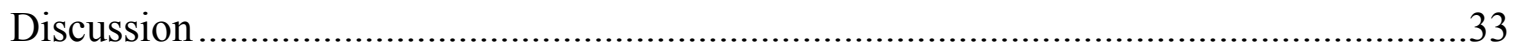

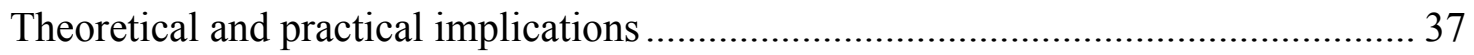

Limitations and directions for future research ........................................................ 40

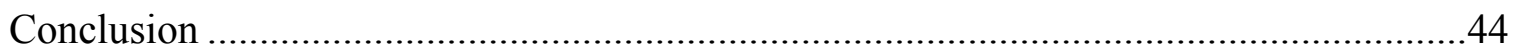

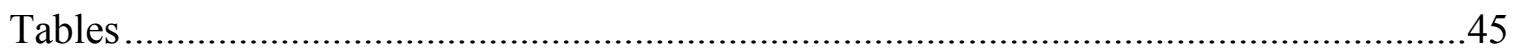

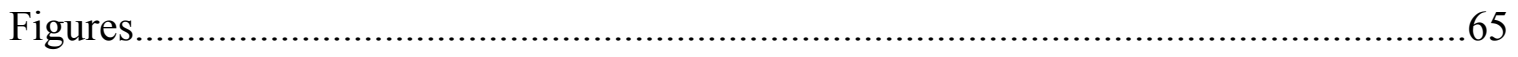

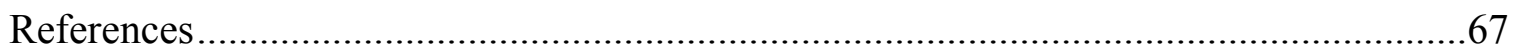

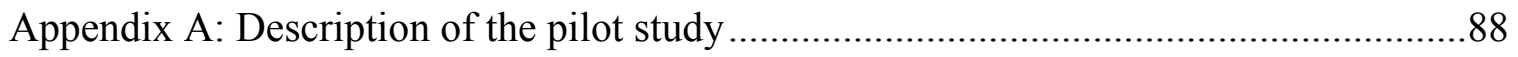

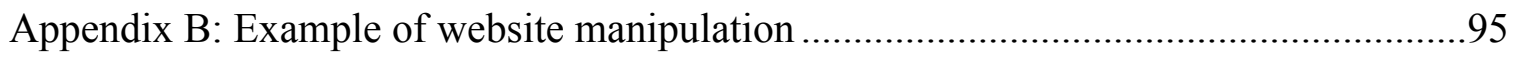

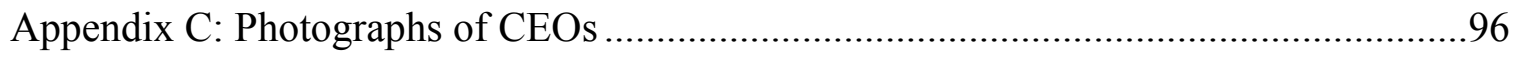

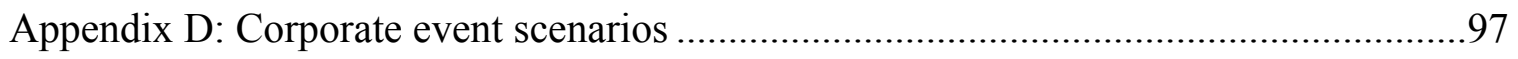




\section{List of Tables}

Table 1: Inter-item correlations and reliabilities for all study variables $(N=$ 396.

Table 2: Means and standard deviations for all study variables, by CEO race $\mathrm{x}$ gender

Table 3: Means and standard deviations for Black female CEOs across all study variables, by error.

Table 4: Means and standard deviations for Black male CEOs across all study variables, by error. 48

Table 5: Means and standard deviations for White female CEOs across all study variables, by error.

Table 6: Means and standard deviations for White male CEOs across all study variables, by error .50

Table 7: MANOVA tests of significance for main effect of corporate error (H1).

Table 8: Bootstrapped (10,000 samples) mediation analyses for the effect of CEO identity (race $\mathrm{x}$ gender) on leader perceptions through attributions of responsibility $(N=396)$

Table 9: Bootstrapped (10,000 samples) mediation analyses for the effect of CEO identity (race $\mathrm{x}$ gender) on organization perceptions through attributions of responsibility $(N=$ 396)

Table 10: Bootstrapped (10,000 samples) moderated mediation analyses for the effect of corporate error context on the influence of CEO identity (race x gender) on leader perceptions through attributions of responsibility $(N=396)$

Table 11: Bootstrapped (10,000 samples) moderated mediation analyses for the effect of corporate error context on the relative conditional influence of CEO identity (race $\mathrm{x}$ gender) on leader perceptions through attributions of responsibility $(N=396)$

Table 12: Bootstrapped (10,000 samples) moderated mediation analyses for the effect of corporate error context on the influence of CEO identity (race x gender) on organization perceptions through attributions of responsibility $(N=396)$

Table 13: Bootstrapped (10,000 samples) moderated mediation analyses for the effect corporate error context on the relative conditional influence of CEO identity (race $\mathrm{x}$ gender) on organization perceptions through attributions of responsibility $(N=396)$ 
RACE AND GENDER ON CORPORATE ERRORS

\section{List of Figures}

Figure 1: Mediation Model.................................................65

Figure 2: Moderated Mediation Model.........................................66 


\section{Introduction}

At $0.6 \%$ of Fortune 500 CEOs, there are currently three Black executives serving as leaders of the 500 largest corporations in the United States (Wiener-Bronner, 2017) ${ }^{1}$. None of them are Black women. The study of racial minority and female leaders has remained a substantial area of research for decades (e.g., Eagly \& Karau, 2002;

Greenhaus, Parasuraman, \& Wormley, 1990; Knight, Hebl, Foster, \& Mannix, 2003; Lyness \& Heilman, 2006; Schein, Mueller, Lituchy, \& Liu, 1996). Yet, the number of racial minority and female CEOs remains small (McGirt, 2017; White, 2017) and is actually decreasing in comparison to White and male executives, even as research continues to suggest that female and non-White leaders can serve as role models that inspire others and make success seem attainable (e.g., Aronson, Jannone, McGlone, Johnson-Campbell, 2009; Lockwood, 2006; Morgenroth, Ryan, \& Peters, 2015; Stout, Dasgupta, Hunsinger, \& McManus, 2011).

One potential reason for this dwindling number are the disadvantages that female and racial minority leaders experience when in these positions. A considerable body of evidence has established that there is a perceived incompatibility between sociallyprescribed gender and race stereotypes and the leader prototype (e.g., White, male, assertive, intelligent; Lord, Foti, \& de Vader, 1984; Rosette, Leonardelli, \& Phillips, 2008), which contributes to negative leader perceptions and evaluations for racial/ethnic minority and female leaders (e.g., Eagly \& Karau, 2002; Eagly, Karau, \& Makhijani,

\footnotetext{
${ }^{1}$ As of June 2018, there are 24 female Fortune 500 CEOs (Zarya, 2018). Only three (12.5\%) are nonWhite: Indra Nooyi (Indian American), Geisha Williams (Cuban), and Joey Wat (Chinese).
} 
1995; Greenhaus et al.,1990; Swim \& Sanna, 1996; Walker, Madera, \& Hebl, 2013). However, this body of research has primarily focused on comparing White male to White female leaders to uncover gender differences and White male to Black male leaders to uncover racial differences, and little has been done to examined the impact of having multiple stigmatized (i.e., intersectional) identities on one's evaluation as a leader. To date, past research suggests that Black female leaders elicit both positive (Livingston, Rosette, \& Washington, 2012) and negative (Rosette \& Livingston, 2012) evaluations, which only highlights the need for a nuanced examination of the underlying psychological processes that may be responsible for these inconsistent findings.

In this thesis, I intend to rectify this inconsistency by investigating how contextual factors (operationalized here as the types of errors organizational leaders are associated with) interact with identity characteristics (CEO race and gender) to influence perceptions of leaders, perceptions of the organizations they lead, and identify underlying attributional factors as a potential explanatory mechanism. First, I describe a dualprocessing approach to evaluating leaders in the context of corporate errors. Second, I introduce attribution theory and discuss the role of attributions in the leader evaluation process. Third, I embed the dual-processing approach and attribution theory within one coherent framework: the justification-suppression model (JSM) of the expression and experience of prejudice (Crandall \& Eshleman, 2003). Fourth, I posit that stereotypes derived from leader identities may cue different attributions about the leaders' culpability 
in the context of organizational errors, resulting in differential evaluations of the leaders and their organizations. Fifth, I outline the methodology to evaluate these relationships and interpret the results from analyses. Finally, I discuss implications, as well as theoretical and practical contributions. 


\section{The Evaluation of Leaders}

Despite a substantial shift in the representation of minorities and women in toplevel leadership positions, a substantial body of evidence demonstrates that these leaders not only face greater challenges acquiring top-level positions, but also more likely face various forms of workplace discrimination. For instance, Knight and colleagues (2003) compared White and Black leaders and found evidence of aversive racism, such that individuals gave lower ratings to Black leaders and White subordinates and positive ratings to White leaders and Black subordinates. That is to say, "people who violate their stereotypical social roles are viewed more negatively than those who conform to their proscribed societal roles (Knight et al., 2003; p. 90; see also Heilman, 2012; Ruggs, Hebl, Walker, \& Fa-Kaji, 2014). As such, this study demonstrates that stereotypic perceptions towards Black people as subordinates (e.g., perceived incompetence) contributes to negative evaluations towards Black leaders, but not Black employees. Examining the diversity of Fortune 500 chief executives, although there were a record number of female CEOs in the Fortune 500 in 2017 (32 women), by 2018 that number dropped to 24 (a 25\% decline; Fortune Editors, 2017; Zarya, 2018). Recently, Dwivedi, Joshi, and Misangyi (2018) explored factors that influenced an incoming woman CEO's postsuccession performance, and found that women CEOs were more successful in their new role when their male predecessor promoted gender-inclusive gatekeeping (e.g., handing over the legacy). In other words, this evidence reveals that the success of female leaders rests in the hands of men. 
Early research on leadership revealed that there are prototypical ideals about the individual qualities leaders should possess that form the basis of leader perceptions (e.g., intelligent, outgoing, aggressive, industrious; Lord, et al., 1984). Implanting this into social role theory (Eagly, 1987), these prescriptive leadership qualities closely correspond to agentic characteristics stereotypically associated with men. Much later, Rosette and colleagues (2008) illustrated that "being White" is also an attribute perceived to be prototypical of effective leadership. Nevertheless, research has also demonstrated that leaders are evaluated based on individual-level characteristics as well as organizationlevel characteristics. Carton and Rosette (2011) outlined two processing systemsinference-based and recognition-based processing — that affect how individuals may evaluate leaders across these levels. For instance, an inference-based processing approach lends support to the idea that observers infer internal qualities of a leader's ability from firm performance outcomes, regardless of the leader's race or gender. Conversely, the recognition-based processing approach suggests that (un)favorable leader evaluations are based on a mixture of observer's pre-existing schemas of prototypical leaders and the person in that leader position. Supported in previous research, this approach suggests that individuals may be more inclined to devalue female and racial/ethnic minority leaders due to their dissonance with the leader prototype. Therefore, I contend that inference- and recognition-based processes can provide a constructive framework for understanding the attributions associated with leader behaviors and how identity-related characteristics can affect these attributions, respectively. 


\section{Inference-based Processing: The Impact of Causal Attributions on Perceived}

\section{Responsibility}

Attribution theory (Heider, 1958; Jones \& Davis, 1965; Kelley, 1967; Weiner, 1985) suggests that people have a propensity to make sense of their social environment by making attributions (i.e., causal inferences) about the behavior of others and interpreting factors that lead to success and failure (see Kelley \& Michela, 1980 for a review). Attributions are inferences based on cause-and-effect analyses utilized to understand the outcomes and factors that contribute to specific events and behaviors (Malle, 2011; Martinko, 1995). According to previous research, these causal attributions

play a central role in consumer judgments and comprise the inference-based processing system (Folkes, 1988; Klein \& Dawar, 2004).

Indeed, a meta-analysis illustrated that attributions can account for a considerable portion of variance in several organizational outcomes (e.g., selection, performance appraisal, leader-member exchange), and that these attributions stem from both internal and external factors (Harvey et al., 2014). Within the leadership literature, some studies have shown that individuals are motivated to make internal attributions (e.g., personal disposition) for leader performance as opposed to external attributions (e.g., environmental or situational influences; Ashkanasy \& Gallois, 1994; Cronshaw \& Lord, 1987; Weber, Camerer, Rottenstreich, \& Knez, 2001). That is, when evaluating leaders, people primarily make attributions based on perceptions of the leader's ability instead of 
situational factors (e.g., market fluctuations; Bligh, Kohles, Pearce, Justin, \& Stovall, 2007; Emrich, 1999; Meindl \& Ehrlich, 1987; Meindl, Ehrlich, \& Dukerich, 1985).

Other leadership research suggests that people derive attributions of leader performance from external factors, based on group, community, or organizational outcomes. An implication of this body of research is that while people link successful corporate performance to effective leadership, people also associate poor corporate performance to a lack of prototypical leadership. For example, Bruckmüller and Branscombe (2010) demonstrated that although attributes typical of male leaders (e.g., independent, competitive, charismatic) were more predictive of leader performance in successful organizations, attributes typical of female leaders (e.g., ability to encourage and build courage in others) were more predictive of leader performance for organizations associated with a controversy. Furthermore, this literature has shown that people attribute external factors (e.g., lack of team support) to internal characteristics of leaders (e.g., leader incompetence). For instance, Dutton and Dukerich (1991) illustrated that corporate failures led perceivers to judge not only the organization as "bad," but also the members within that organization —-that "bad" organizations are filled with "bad" members and operated by "bad" or ineffective leaders. In addition, Martinko, Breaux, Martinez, Summers, and Harvey (2009) evaluated attributions of responsibility for leaders involved in the response to Hurricane Katrina (e.g., local New Orleans officials, Governor of Louisiana, President George Bush, Federal Emergency Management Agency). Using archived speeches and commentaries, they demonstrated that people 
(e.g., media, observers) consistently attributed problems associated with the Katrina aid and rescue efforts to personal characteristics of leaders.

Studies have shown that negative attitudes and judgments due to inference-based processing are quite strong, such that not only do perceivers make attributions of responsibility towards an actor directly involved, but also may extend judgments of responsibility to other factors (or people) simply by association. For instance, research on stigma has illustrated that individuals derogate others perceived to be in a relationship (or related in some way) with a stigmatized person or event (e.g., Hebl \& Mannix, 2003; Hernandez et al., 2016; Kessler, Mahoney, Randolph-Seng, Martinko, \& Spector, 2017; Neuberg, Smith, Hoffman, \& Ressel, 1994). This stigma-by-association effect has also transpired quite clearly in recent media coverage of corporate failures, especially those perceived to be egregious, which also illustrates the strength these causal attributions. For example, when Chick-fil-A CEO, Dan Cathy, made a statement opposing same-sex marriage, not only did people protest and boycott Chick-fil-A, but employees also faced negative backlash from customers regardless of the employees' individual attitudes towards same-sex marriage (Shapiro, 2012). In addition, when a video showing Dr. David Dao being forcibly removed from a United flight circulated online, not only were the officers removing Dr. Dao blamed, but so was United, as an organization, the CEO of United, and even Dr. Dao (Meier, 2017). It follows from the examples that attributions of responsibility can be, and often are, ascribed to CEOs in the presence of an organizational 
failure or crisis, regardless whether the leader directly contributed to the mistake. As such, I predict:

Hypothesis 1: There will be a main effect of corporate error on perceptions of the leader and the organization such that leaders that are associated with an error will receive lower evaluations in terms of perceived leader attributes $(H 1 a)$, leader effectiveness $(H 1 b)$, leader response $(H 1 c)$, salary $(H 1 d)$, promotion $(H 1 e)$, behavioral intentions (Hlf), and corporate reputation $(H l g)$.

\section{Recognition-based Processing: The Intersection of Race and Gender}

The recognition-based processing approach asserts that race and gender contribute to less favorable evaluations towards female and non-White leaders due to notions that women and non-White leaders are incompatible with the prototypical White male leader (Lord et al., 1984). A large body of research reveals that the perceived incompatibility between the qualities necessary for effective leadership and the female gender role (Biernat, 1995; Eagly, 1987; Heilman, 1983; Eagly \& Karau, 2002) contributes to unfavorable evaluations towards female leaders (e.g., Bowen, Swim, \& Jacobs, 2000; Brescoll \& Uhlmann, 2008; Eagly \& Karau, 2002; Lyness \& Heilman, 2006; Rudman \& Glick, 2001; Haslam \& Ryan, 2008; Willemsen, 2002). Likewise, several studies have also shown that Black leaders are perceived more negatively as leaders when compared to White leaders (e.g., Avery, McKay, Volpone, \& Malka, 2015; Cook \& Glass, 2013; 2014; Greenhaus et al., 1990; Knight et al., 2003; Powell, Butterfield, \& Parent, 2002; 
Rosette et al., 2008). However, very little systematic research has examined the effect of the intersection race and gender on leader perceptions.

There are currently two competing predictions that may explain how perceptions of Black female leaders compare to those of White male, White female, and Black male leaders. One such perspective is the double jeopardy hypothesis, which contends that Black women suffer additive disadvantages due to being both Black and female (Almquist, 1975; Beale, 1970). Rosette and Livingston (2012), found that Black women were penalized the most for making mistakes, which aligns with this double jeopardy phenomenon. In addition, the overwhelming underrepresentation of Black women in executive leadership positions is likely the clearest indicator of support for double jeopardy (Sanchez-Hucles \& Davis, 2010). An alternative perspective suggests that negative evaluations targeted at prototypic female (i.e., White female) or Black (i.e., Black male) leaders, are not simply the combination of both gender and racial characteristics; individuals may perceive that Black women possess typical leader behaviors that neither Black male or White female leaders possess (Ghavami \& Peplau, 2013). As such, this prediction contends that the combination of race and gender produces an intersectional invisibility effect, which grants Black female leaders the opportunity to escape the same level of discrimination that White female leaders or Black male leaders may face (Purdie-Vaughns \& Eibach, 2008). Proponents of this proposition argue that it is individuals with single stigmatized identities who stand vulnerable to greater oppression, because it is this group that represents the prototype of their social 
group (i.e., Black men as the prototype of Black). As such, individuals with multiple subordinate identities are rendered invisible, or in some cases, granted more lenient evaluations (Livingston et al., 2012).

Previous research suggests that both the double jeopardy and intersectional invisibility predictions contribute to leader evaluations of Black women. Supporting the double jeopardy proposition, Rosette and Livingston (2012) found that under conditions of poor organizational performance, Black female leaders were evaluated more negatively than Black male and White female leaders. However, Livingston and colleagues (2012) demonstrated that Black female leaders did not receive the same agentic penalty that White female leaders received. Supporting the intersectional invisibility proposition, this study demonstrated that Black female leaders were evaluated more similarly to White male leaders (who were rated highest) than White female and Black male leaders (Livingston et al., 2012; Rosette, Koval, Ma, \& Livingston, 2016). Conversely, another study revealed that in situations of organizational success, White men were evaluated most favorable and Black men, Black women, and White women were evaluated similarly and lower than White men. Thus, although Black female leaders are perceived to have agentic qualities more similar to the White male leader prototype (compared to Black or female leaders), they are more likely to receive harsher penalty when associated with poor firm performance.

The implications of these contradictory perspectives suggest that perceptions of Black female leaders may not be driven by performance or social categories alone, but in 
some combination of both (e.g., Rosette et al., 2016). A particularly interesting finding however is that Black women leaders were perceived most unfavorably when observed under the context of poor organizational performance (Rosette \& Livingston, 2012). Therefore, negative organizational performance may be especially threatening to Black women leaders at least in part from their dual stigmatized identities. However, when Black women leaders are not associated with an error, past research suggests that they are perceived more equal to White men leaders relative to Black men or White female leaders (Livingston et al., 2012). As such, I predict:

Hypothesis 2: Corporate error, $\mathrm{CEO}$ race, and $\mathrm{CEO}$ gender will have an interactive effect on leader and organizational perceptions such that the effect of corporate error on negative leader evaluations will be stronger for Black women CEOs relative to White men, White women, and Black men CEOs. Specifically, Black women CEOs will receive the most negative ratings for perceived leader attributes $(H 2 a)$, leader effectiveness $(H 2 b)$, leader response $(H 2 c)$, salary $(H 2 d)$, promotion $(H 2 e)$, behavioral intentions $(H 2 f)$, and corporate reputation $(H 2 g)$ relative to White men, White women, and Black men CEOs. 


\section{The Justification of Prejudice towards Stigmatized CEOs}

Examining how inference- and recognition-based processes may lead to prejudicial judgments of leaders as a function of race and gender can be addressed in the context of the justification-suppression model (JSM) of the expression and experience of prejudice (Crandall \& Eshleman, 2003). The JSM asserts that feelings of genuine prejudice are impacted by justification and suppression factors that compel individuals to (or not to) express this prejudice openly. Crandall and Eshleman (2003) define prejudice as "a negative evaluation of a social group or a negative evaluation of an individual that is significantly based on the individual's group membership" (p. 414). Justification factors are "any psychological or social process that can serve as an opportunity to express genuine prejudice without suffering external or internal sanction," (Crandall \& Eshleman, 2003; p. 425). According to the JSM, justification factors may be based on stereotypes, ideologies, or attributions.

I propose that inference- and recognition-based processing systems work in conjunction to influence prejudicial judgments of minority CEOs in the context of a corporate error. For the purpose of this study, corporate errors are operationalized as negative events associated with CEOs in order to provide participants with evidence to judge a leader negatively, thereby justifying the expression of prejudice. In line with the JSM, I predict that the expression of prejudice towards leaders with stigmatized identities will be justified when associated with corporate errors opposed to leaders who are not associated with corporate errors. Given pervasive stereotypes rendering non-White and 
women incongruent with prototypical leaders (Rosette et al., 2008), race- and genderbased genuine prejudice will impact the effect of attributions of responsibility on overall evaluations of leaders and the organization (Lord et al., 1984; Rosette et al., 2008). Supporting this, a number of empirical studies illustrate that causal attributions of responsibility can lead to increased expressions of prejudice towards stigmatized others (Crandall, 1994; Hegarty \& Golden, 2008; King, Shapiro, Hebl, Singletary, \& Turner, 2006; Sakalli, 2002; Zucker \& Weiner, 1993). In one such study, King and colleagues (2006) found that attributions (i.e., perceived controllability over body size) influenced the degree to which interpersonal discrimination was expressed towards obese (vs. average weight) customers. More specifically, customers who engaged in activities that contribute to weight gain (e.g., drinking a high-calorie beverage) experienced greater interpersonal discrimination from store personnel than customers who engaged in weight loss activities (e.g., drinking a diet beverage). Thus, participants in this study felt justified in expressing prejudice due to the attributions associated with the actions of the target customers.

It follows from this body of research that the integration of the JSM with inference- and recognition-based processes of evaluating leaders can be valuable in understanding how prejudice impacts the evaluation of minority leaders and the organizations they lead (King et al., 2006). In this study, I assess attributions of responsibility - the degree to which participants hold the CEO responsible for the performance of the firm - to examine whether a CEO's race and gender impact the extent 
to which observers hold a leader responsible for a publicized controversy. Specifically, I predict that attributions of responsibility will be stronger for minority leaders compared to White male CEOs, and the strongest for Black female CEOs. As such, individuals will make harsher attributions of responsibility when Black female CEOs are associated with an organizational failure, which will lead to greater judgments of responsibility relative to Black men, White women, and White men leaders.

Hypothesis 3 (see Figure 1): There will be an indirect effect of attributions of responsibility toward the $\mathrm{CEO}$ in the relations between $\mathrm{CEO}$ race and gender and perceived leader attributes $(H 3 a)$, leader effectiveness $(H 3 b)$, leader response $(H 3 c)$, salary $(H 3 d)$, promotion $(H 3 e)$, behavioral intentions $(H 3 f)$, and corporate reputation $(H 3 g)$. 


\section{Legitimization of Stigmatized CEOs}

Although I predict that Black women CEOs will receive particularly negative attributions and evaluations in the context of errors (in general), I assert that the contextual nature of the error should further affect these relations. Specifically, I predict that perceptions of diverse leaders will be more positive when the organization is shown to have a diversity-related issue. Previous research on compensatory stereotypes and the social consequences of attributing negative treatment to discrimination, provide two explanations for why a stigmatized identity may function to legitimize one's position as a leader (Carton \& Rosette, 2011; Kaiser \& Miller, 2001; Rosette et al., 2016).

First, past research suggests that CEOs may be perceived to be more suited to resolve diversity issues as a function of minority group membership. That is, people may believe that being Black, being a woman, or being a Black woman endows that person with better abilities relative to White male leaders when there is a diversity-related issue at hand. One study demonstrated that people apply different stereotypes when perceiving Black leaders depending on whether performance was successful or not (Carton \& Rosette, 2011). Specifically, perceivers ascribed positive qualities (e.g., athletic) to Black leaders following a success and negative qualities (e.g., incompetence) following a failure. However, both qualities — athletic and incompetent - exist within prescriptive stereotypes held towards Blacks. This allows, Carton and Rosette (2011) assert, individuals to make positive evaluations while endorsing cultural stereotypes towards Black leaders. That is, under the context of successful performance, people judged that 
Black leader performance was more due to athletic ability rather than to intelligence or decision-making skills (as was judged the performance of White leaders).

These compensatory stereotypes applied to leader evaluations allow people to shift stereotypic beliefs towards others across varying contexts (e.g., Biernat, Sesko, \& Amo, 2009; Brown, Martinez, \& Hebl, 2018; Singletary \& Hebl, 2009; Yzerbyt, Kervyn, \& Judd, 2008). Considering that some stereotypes about Blacks (e.g., unintelligent, lazy, angry) and women (e.g., emotional, devious, sensitive) typically lead to less favorable evaluations of leader qualities, other stereotypes towards Blacks (e.g., agentic, funny, relational) and women (e.g., warm, communal, encouraging) may be more readily incorporated into attribution processes and linked to more positive evaluations in certain contexts (Carton \& Rosette, 2011; Devine 1989; Eagly \& Karau, 2002). From this perspective, I predict that the stereotypes associated with stigmatized identities will not inherently be used to justify negative evaluations towards leaders. Rather, stereotypic qualities associated with race, gender, or the intersection of both will in fact justify more lenient evaluations of atypical leaders depending on the type of organizational performance (Rosette \& Livingston, 2012).

Second, past research has revealed that ascribing negative events (e.g., poor evaluation, bad personal encounters) to discrimination can lead unstigmatized individuals to negatively perceive stigmatized others as hypersensitive, dramatic, or "complainers" (Kaiser \& Miller, 2001), and believe that minority groups victimize themselves by 
“crying prejudice” (Czopp \& Monteith, 2003; Swim, Cohen, \& Hyers, 1998). An implication from this literature suggests that these negative social costs may stem from the belief that minorities are merely acting out of their own self-interest, or out of the interest of their ingroup. Thus, perceivers may believe that minority CEOs are similarly motivated to act in line with their own self-interests or the interests of their ingroup. This belief towards the CEO may prompt individuals to evaluate minority CEOs as more personally invested in addressing a diversity-related issue because of potential self- or group-serving motivations. From this perspective, a leader's stigmatized identity (or identities) will serve to legitimize one's position as a leader depending on the organizational context in which that leader is observed, leading to more favorable evaluations of minority leaders (see Figure 2). In other words, I predict that when Black female leaders are associated with a diversity-related corporate error, weaker attributions of responsibility will contribute to more lenient leader evaluations compared to White male leaders. Furthermore, although I predict that White female and Black male leaders will receive more lenient evaluations compared to White male leaders (and harsher evaluations compared to Black women) when associated with a diversity-related error, I predict no significant difference between perceptions toward White female leaders compared to Black male leaders.

Given the arguments that general types of errors should activate justification factors leading to the expression of prejudice and that diversity-related errors should result in higher perceptions of legitimacy for stigmatized leaders, I predict the following: 
Hypothesis 4 (see Figure 2): Corporate error will moderate the indirect effect of attributions on the interactive effect of CEO race and gender on perceived leader attributes $(H 4 a)$, leader effectiveness $(H 4 b)$, leader response $(H 4 c)$, salary $(H 4 d)$, promotion $(\mathrm{H} 4 \mathrm{e})$, behavioral intentions $(\mathrm{H} 4 \mathrm{f})$, and corporate reputation $(\mathrm{H} 4 \mathrm{~g})$ such that in the non-diversity related corporate error condition Black female CEOs will elicit harsher attributions and more negative outcomes and in the diversity related corporate error condition Black female CEOs will elicit more lenient attributions and more positive outcomes. 


\section{Method}

\section{Participants}

An a priori power analysis, using a medium effect size $(0.25)$ to compute the number of participants needed to achieve a power of 0.95 revealed that a minimum of 251 participants ( $\sim 20$ participants per group) would be needed to achieve the minimum power threshold. A total of 400 participants in the United States were recruited on Amazon's Mechanical Turk (MTurk). Four participants failed to pass the manipulation check (described later) and were thus excluded from analyses, resulting in a final sample of 396. Participants were mostly male $(53 \%, n=211)$, heterosexual $(83 \%, n=326)$, and were, on average, 35.06 years of age $(S D=12.00)$. In addition, the majority of participants indicated that they were White $(67 \%, n=266)$, followed by Asian/AsianAmerican $(16 \%, n=63)$, Black/African-American $(8 \%, n=32)$, biracial/multi-racial $(4 \%, n=15)$, Native American/Alaska Native $(3 \%, n=10)$, “Other” $(1 \%, n=4)$, Native Hawaiian/Pacific Islander $(1 \%, n=3)$, and "Prefer not to answer" $(1 \%, n=3)$. Furthermore, a majority of participants were employed full-time $(65 \%, n=256)$ and had exposure to a supervisory role in an organizational setting $(62 \%, n=246)$. Participants were compensated $\$ 1.00$ for their participation in the survey.

\section{Procedure}

This study used a 2 (CEO race: White vs. Black) x 2 (CEO gender: male vs. female) x 3 (corporate error: no error vs. diversity error vs. non-diversity error) betweensubjects experimental design. Participants were directed to an online survey involving an 
online news article focused on a CEO's response to an event involving a fictitious organization. More specifically, participants viewed a full-page screenshot of an ostensible CNN Money webpage and were instructed to read a news article covering the chief executive's response to a manipulated scenario involving the firm's performance. After viewing and reading the news article, participants provided ratings based on their evaluation of the chief executive and of the organization. Finally, participants provided demographic information and responded to manipulation checks to ensure sufficient knowledge of their manipulation condition.

\section{Materials}

All materials (e.g., websites, CEO photographs, CEO names) were thoroughly pilot tested prior to experimentation (see Appendix A for a detailed description of the pilot test). Each web page contained the manipulations for $\mathrm{CEO}$ race, $\mathrm{CEO}$ gender, and the corporate error (Appendix B). Each corporate scenario described that a CEO, Jordan Williams, of an organization, Cook \& Price Financial, is responding to a situation either involving a corporate error (diversity-related or non-diversity related) or a neutral scenario not involving an error. I developed corporate error scenarios by finding and adapting published business news articles that included corporate errors and neutral events, such as expanding business to a new territory. Adapting real news articles provided narratives that mimic bona fide news coverage and scenarios that have occurred in actual organizations, as opposed to creating errors that have not (or perhaps would not have) occurred. I purposely changed any additional names included in the original 
articles when constructing scenarios for this study. In addition, identical apologetic responses were presented in conditions manipulating a corporate error, and a neutral message in the no error control condition.

Control condition. The pilot test revealed no significant differences within the scenarios in terms of the degree to which participants believed these events were positive, negative, bad, and severe (Appendix A). As such, I retained two control conditions for use in the online survey. The first control condition describes a scenario in which Cook \& Price Financial announces that their new CEO has just released their first official statement as the new CEO. This scenario was adapted from news coverage based on Bracket (Everett, 2018). The second control condition describes a scenario in which the CEO announces that Cook \& Price Financial is opening a new office. This scenario was adapted from news coverage based on Opcity (Hawkins, 2017).

Diversity corporate error. For the purpose of this study, diversity errors are defined as organization-level mistakes that differentially and negatively impact employees or customers based on race or gender (e.g., pay discrimination). Both diversity-related errors were adapted to involve both race- and gender-based discrimination so that one form of disparate treatment did not significantly impact participants' responses. The pilot test revealed no significant differences within the scenarios in terms of the degree to which participants believed these diversity related errors were positive, negative, bad, or severe (Appendix A). As such, I retained two diversity error conditions for use in the online survey. The first diversity error condition 
describes a scenario in which the CEO releases a statement amid charges that Cook \& Price is responsible of pay discrimination towards women and racial minority employees. This scenario was adapted from news coverage based on Google (Guynn, 2017). The second diversity error condition describes a scenario in which Williams releases a statement in response to allegations of loan discrimination towards women and racial minority clients. This scenario was adapted from news coverage based on BancorpSouth (McCoy, 2016).

Non-diversity corporate error. For the purpose of this study, non-diversity errors are defined as organization-level mistakes that differentially and negatively impact employees or customers, but are not inherently based on race or gender. The pilot test revealed no significant differences within the scenarios in terms of the degree to which participants believed these non-diversity related errors were positive, negative, bad, and severe (Appendix A). As such, I retained two control conditions for use in the online survey. The first non-diversity error condition describes a scenario in which the CEO apologizes on behalf of Cook \& Price employees for failing to provide several clients their pension payments. This scenario was adapted from news coverage based on MetLife Inc. (Bloomberg News, 2018). The second control condition describes a scenario in which the CEO releases a statement amid charges of nepotism in hiring practices. This scenario was adapted from news coverage based on JP Morgan Chase (Zarroli, 2016).

CEO name and photographs. Several potential names for the CEO were pilot tested to confirm the name's fidelity across CEO gender and race conditions. There were 
no significant differences among the names included in the pre-test, thus I chose the name Jordan Williams based on face validity. This name was held constant across all manipulated conditions. Additionally, several professional headshots were pre-tested (see Appendix A for detailed description). Two exemplars of each race/gender combination were used in the study (see Appendix C).

\section{Measures}

Leader attributes. Guided by the stereotype content model (SCM; Fiske, Cuddy, Glick, \& Xu, 2002) and attributes developed by Lord and colleagues (1984), participants were asked to evaluate the CEO on leader attributes. Leader competence was measured with five items: competent, intelligent, confident, independent, competitive. Leader warmth was measured with four items: tolerant, warm, good-natured, sincere. Leader morality was measured with four items: ethical, has integrity, moral, honest). Leadership characteristics (Lord et al., 1984) were measured with six items: insightful, hard-working, assertive, conscientious, logical, creative. All items were measure using a 5-point, Likerttype scale anchored by 1 (not at all) and 5 (extremely). The full measure demonstrated acceptable reliability $(\alpha=.96)$. These dimensions were included into a single measure in order to not only capture stereotypic perceptions of warmth and competence due to group membership (i.e., SCM), but to also examine whether perceptions of morality and known leader qualities shift as a function of the CEO's race, gender, and the context of the corporate error. 
Leadership effectiveness. Participants were asked to evaluate the CEO on leader effectiveness with four items (Rosette \& Livingston, 2012): "I think the CEO is an effective leader," "I would have confidence in the CEO's ability to be successful," "I would recommend the CEO for other leader positions," and "An organization led by the CEO would be effective." The remaining items were measured using a 7-point, Likerttype scale anchored by 1 (not at all agree) and 7 (completely agree), unless otherwise noted. This measure demonstrated acceptable reliability $(\alpha=.95)$,

Leader response. Participants were also asked to evaluate the leader's response with four items, created for the purpose of this study. The four items were: "I think the CEO's response was effective in managing the situation," "I think the CEO's response was sincere," "I felt that the CEO's response carried a sense of urgency," and "I think the CEO's response is authentic." This measure demonstrated acceptable reliability $(\alpha=.91)$.

Salary. Participants were shown the current salary of the CEO (\$2 million), and were asked to either increase or decrease the salary of the executive (Livingston et al., 2012; Walker et al., 2013). Participants were asked to increase or decrease the salary by increments of $\$ 100,000$. Salary values ranged from $\$ 0$ to $\$ 4$ million $(M=\$ 1.82$ million, $S D=\$ 880,000)$

Promotion. Participants rated the extent to which they believed the executive should receive a promotion using a single item. To do so, participants were told that at the time of the media coverage, the CEO was being considered for promotion to the 
chairman of the board of directors and were asked, "To what extent do you agree that the CEO should receive this promotion?" Scores ranged from 1 to $7(M=3.57, S D=1.79)$.

Behavioral intentions toward the organization. Behavioral intentions were measured using four items adapted from Ryu, Han, and Kim (2008) and Smith, Martinez, and Sabat (2016). The four items were: "I would apply to work at this organization," "I would use this organization's product/service in the future," "I would recommend this organization's product to a family member or a friend," and "I would use a competing organization before using this organization's service" (reverse-coded). This measure demonstrated acceptable reliability $(\alpha=.71)$

Organizational reputation. Organizational reputation was measured with five items used by Coombs and Holladay $(2002 ; 2008)$. The five items were: "The organization is concerned with the well-being of the public," "The organization is basically dishonest" (reverse-coded), "I do not trust the organization to tell the truth about this event" (reverse-coded), "Under most circumstances, I would be likely to believe what the organization says," and "The organization is not concerned with the well-being of the public" (reverse-coded). This measure demonstrated acceptable reliability ( $\alpha=$ $.80)$.

Attributions of responsibility. Attributions of responsibility were measured using six-items, adapted from the Causal Dimension Scale II (CDSII; McAuley, Duncan, \& Russell, 1992). The six items were: "The event is something that reflects an aspect of the CEO," "The event is something manageable by the CEO," "The event was caused by 
the CEO," "The cause of the event is something over which the CEO had power," "The cause of the event is attributable to something about the CEO," and "The cause of the event is something the CEO should be blamed for." The items were assessed using a 7point, Likert-type scale anchored by 1 (not at all agree) to 7 (completely agree). This measure demonstrated acceptable reliability $(\alpha=.91)$.

Demographic characteristics. Participants provided the following demographic information to provide contextual information of the sample: age, gender, race/ethnicity, sexual orientation, education, employment status, supervisory status, and partner status.

Manipulation and attention checks. To ensure sufficient attention to the manipulated materials, participants were instructed to recall the executive's gender, race, and select the correct image of the CEO. Guided by (Huang, Bowling, Liu, \& Li, 2015), I included three bogus-item attention checks throughout the survey to identity careless responders (e.g., "I think the CEO's response was in Spanish"). 


\section{Results}

I used two different analytic techniques to test my predictions. To test Hypotheses 1 and 2 , I conducted a 2 (Race) x 2 (Gender) x 3 (Corporate error) multivariate analysis of variance (MANOVA) using a general linear modeling approach with leader perceptions (e.g., leader evaluation, perceived leader effectiveness, evaluation of leader's response, salary change, and promotion recommendation) and organization perceptions (e.g., behavioral intentions and corporate reputation) as dependent variables. The MANOVA provided a way to investigate the impact of corporate error, leader race, and leader gender on participant's evaluations, both leader and organization perception variables, simultaneously. In addition, I utilized a MANOVA to examine whether or not main effects of leader race or leader gender existed, in spite of having no formal prediction for the main effects of leader gender or race. To test Hypotheses 3 and 4, I utilized Hayes' PROCESS to understand the conditional influence of corporate error on evaluations of the leader and the organization. Given that I was primarily interested in the intersection of race and gender, I combined leader race and gender into a single, CEO identity, variable and used that combined variable as a predictor. Taken together, these separate methodological approaches allowed me to not only examine group means as a function of corporate error, leader race, and leader gender, but also to determine whether (or not) attributional judgments and the corporate condition (i.e., error) significantly impacted evaluations towards leaders as a function of their race and gender. 
Means, standard deviations, and correlations of all study variables can be found in Table 1. Furthermore, Table 2 shows the means and standard deviations of all study variables, by CEO race and gender. Box's test of equality of covariance matrices was significant (Box's $\mathrm{M}=473.64, p<.001$ ), which suggests that the covariance matrices between groups cannot be assumed to be equal. Since this test reveals a violation in the assumption of homoscedasticity, the results from the MANOVA analyses cannot be assumed to stem from an equality of variances across groups within the sample population. The omnibus MANOVA revealed, as predicted, a significant main effect of error, $F(14,742)=10.88, p<.001, \eta^{2}=.18$. However, the predicted three-way interaction between CEO race, CEO gender, and error was not significant, $F(14,740)=$ $0.73, p=.74, \eta^{2}=.01$. Thus, Hypothesis 2 was not supported.

\section{Main Effect of Error on Perceptions of the Leader}

Follow-up univariate analyses showed a consistent main effect of error condition across measures assessing perceptions towards the leader. Means and standard deviations can be found in Tables 3-6. Leaders associated with an error, regardless of error type, were evaluated lower regarding leader attributes compared to leaders not associated with an error, $\left.F(2,376)=40.90, p<.001, \eta^{2}=.18\right)$. Similarly, leaders associated with corporate errors were perceived as less effective compared to leaders not associated with errors, $F(2,376)=43.73, p<.001, \eta^{2}=.19$. In addition, statements from leaders responding to errors were more scrutinized compared to the responses from leaders not associated with errors, $F(2,376)=34.13, p<.001, \eta^{2}=.15$. A significant main effect of 
error condition on assigned salary revealed that, on average, leaders in the control condition were assigned higher salaries than leaders in the error conditions, $F(2,376)=$ $7.05, p=.001, \eta^{2}=.04$. Finally, leaders in the control condition were endorsed to receive a promotion more than leaders associated with corporate errors, $F(2,376)=45.16, p<$ $.001, \eta^{2}=.19$. Follow-up univariate tests of significance, means, and standard errors are displayed in Table 7. Taken together, these results provide support for Hypotheses $1 a-$ le.

\section{Main Effect of Error on Perceptions of the Organization}

Follow-up univariate analyses also demonstrated consistent main effects of error condition across measures assessing perceptions towards the organization. Means and standard deviations can also be found in Tables 3-6. Participants expressed more negative behavioral intentions towards the organization associated with an error, regardless of error, compared to the organization not associated with an error, $F(2,376)=57.41, p<$ $.001, \eta^{2}=.23$. Likewise, the organization received more negative evaluations of corporate reputation when associated with errors compared to when not associated with an error, $F(2,376)=52.64, p<.001, \eta^{2}=.22$. Follow-up univariate tests of significance, means, and standard errors are also displayed in Table 7. Taken together, these results support Hypotheses $1 f$ and $1 g$.

\section{Mediation Analyses}

I used Hayes and Preachers' (2014) bootstrapping method (PROCESS Model 4 using 10,000 bootstrapped samples; see also Hayes, 2017) to investigate Hypothesis 3 , 
the prediction that attributions of responsibility would mediate the effect of $\mathrm{CEO}$ race and gender on participant perceptions of the CEO (e.g., leader attributes, effectiveness, response, salary, and promotion) and the organization (e.g., behavioral intentions and corporate reputation). Given that this predicted relationship is based on the intersection of CEO race and gender, race and gender were coded into a single variable, referred to as CEO identity, and inserted as a multi-categorical predictor. As such, comparisons were made between Black female (referent group), Black male, White female, and White male CEOs. Results indicated that CEO identity did not differentially predict attributions of responsibility (path a) for Black female CEOs $(b=4.15, S E=0.15, p<.001)$ in comparison to Black male CEOs $(b=0.21, S E=0.22, p=.32)$, White female CEOs $(b=$ $0.24, \mathrm{SE}=0.21, p=.26)$, or White male CEOs $(b=0.26, S E=0.21, p=.23)$. Regardless of CEO identity however, results revealed that attributions of responsibility significantly predicted leader attributes $(b=0.09, S E=0.03, p=.002)$, leader effectiveness $(b=0.17$, $S E=0.06, p=.003)$, response $(b=0.14, S E=0.06, p=.012)$, salary $(b=0.09, S E=0.03$, $p=.004)$, behavioral intentions $(b=0.26, S E=0.05, p<.001)$, and corporate reputation $(b=-0.19, S E=0.05, p<.001)$, and marginally predicted promotion $(b=0.12, S E=$ $0.06, p=.056$; see also Table 8 and 9). These results do not provide support for Hypothesis $3(H 3 a-H 3 g)$.

\section{Moderated Mediation Analyses}

I also utilized Hayes and Preachers' (2014) bootstrapping method (PROCESS Model 7 using 10,000 bootstrapping samples; see also Hayes, 2015) to investigate 
whether the relationship between CEO identity and attributions of responsibility leading to differential evaluations of the CEO and the organization depends on the type of corporate error (Hypothesis 4). Similar to the mediation analysis, CEO identity was entered as a multi-categorical predictor, with the control corporate event as the referent group. As in the mediation analysis, Black female CEOs served as the referent group compared to Black male, White female, and White male CEOs. In addition, corporate error (e.g., no error control, diversity error, and non-diversity error) was entered as a multi-categorical moderator. This analysis revealed a significant main effect of error, such that CEOs in the no error condition received stronger attributions of responsibility $(b=4.47, S E=0.263, p<.001)$ when compared to a diversity related error $(b=-1.15, S E$ $=0.372, p=.002)$. However, there was no apparent main effect of corporate error when no error was compared to a non-diversity related error $(b=0.13, S E=0.361, p=.73)$. Furthermore, results did not reveal significant interactive relationships between CEO identity and corporate error in predicting attributions of responsibility, indicating that the non-significant effect of CEO race and gender was not impacted by the context of the corporate error (see Tables 10-13). Taken together, these results do not support Hypothesis $4(\mathrm{H} 4 \mathrm{a}-\mathrm{H} 4 \mathrm{~g})$. 


\section{Discussion}

In this study, I examined the performance-based conditions in which leader race and gender may differentially impact evaluations of the leader and the organization, as guided by research on the justification-suppression model of prejudice (JSM; Crandall \& Eshleman, 2003) as well as inference-based and recognition-based process systems of leadership (Carton \& Rosette, 2011). More specifically, I investigated whether Black women in chief executive positions would be evaluated less harshly when associated with a diversity-related error, thus ameliorating the influence of justification factors (i.e., attributions of responsibility) on the expression of prejudice (i.e., lower leader-based evaluations). Results indicated a main effect of error, such that corporate errors led to harsher evaluations of both the leader and organization, regardless of the error.

Contrary to my prediction however, there was not a significant interaction between race, gender, and corporate error, failing to support Hypothesis 2 (H2a-H2g). Furthermore, multivariate analysis of variance analyses revealed no significant main effects of race or gender on leader and organization perceptions. This finding suggests that participants did not differentially evaluate leaders on the basis on race and gender alone. However, a substantial body of research provides evidence that race and gender, indeed, do impact the evaluation of leaders. I suspect that this finding may be due to the fact that participants were not provided with sufficient material to justify prejudicial responses. That is, participants' suppression factors may have hindered the expression of prejudice in regards to leader and organization perceptions. There are a number of 
reasons through which I believe suppression factors may have remained more salient than justification factors, provided by the corporate error manipulation.

One important reason could be the manipulations themselves. Primarily, the manipulation of the corporate errors may not have provided enough evidence to activate factors justifying prejudice expression. Although the errors were adapted from actual news articles, the narratives may have been ambiguous, speculative, and complex for participants trying to absorb the information at-hand and form evaluative judgments. However, the pre-test did not examine perceptions of article complexity and whether (or not) participants believed the articles were too difficult to interpret. Second, the length of the articles may have reduced the saliency of the CEO's demographic information. Although an image of the CEO was located at the top of each webpage, participants were required to scroll down to read the articles in completion. As participants read further along, as instructed, the details in the article may have become more salient, causing the race and gender of the CEO less salient.

Another potential explanation for the suppression of prejudicial responses may be due to the homogeneity of the study's sample (53\% male, $63 \%$ white, $61 \%$ supervisors). Previous research on color blindness may aid in interpreting this finding (e.g., Apfelbaum, Norton, \& Sommers, 2012; Knowles, Lowery, Hogan, \& Chow, 2009; Richeson \& Nussbaum, 2004). Stemming from research on race, color-blindness endorses the belief that racial group membership should not be noticed or taken into account in intergroup relations. In spite of research illustrating the automatic activation of 
stereotypes (i.e., JSM; Crandall \& Eshleman, 2003), the color-blind ideology remains a prevalent strategy within organizations to manage diversity. As such, by attempting to remain "blind" to race and gender, supervisors may be more likely to automatically endorse color-blindness when evaluating others in leadership positions. Furthermore, Knowles and colleagues (2009) illustrated that the color-blind ideology is a malleable process shaped by social identity based comparisons. As such, the fact that a majority of participants were White men with some supervisory experience, perceiving leaders of color (and women leaders) may have signaled this color-blindness endorsement.

Although color-blindness ideology was not captured in this study, future research should measure for color-blindness (vs. multicultural) ideologies (Plaut, Thomas, \& Goren, 2009; Richeson \& Nussbaum, 2004).

Alternatively, supervisors could have considered the CEOs in the articles as members of a leader ingroup, which may have also rendered race and gender less salient. Previous social psychological research demonstrates that individuals generally perceive ingroup members more positively than outgroup members (e.g., Tajfel \& Turner, 1986). By seeing the CEO as an ingroup member via status as a leader, the race and gender of the CEO may not have mattered as much for participants with supervisory experience, compared to participants without such experience. Furthermore, results indicate that the insignificant effect of CEO identity (CEO race and gender) was not influenced by the context of the corporate error. Stated differently, Black women, Black men, White women, and White men executives were generally evaluated comparably, regardless of 
the firm's performance. According to the JSM, the race and gender of the executive would activate genuine prejudice, and in collaboration with the association to a corporate error, observers would employ this prejudice to evaluate minority leaders more negatively than White men leaders. Although main effects of CEO race and gender were analyzed, these results yielded non-significant findings for leader and organization perceptions for both race and gender. The finding that Black women, Black men, and White women leaders were evaluated comparably to White men contradicts previous research comparing subordinate identities in leadership roles. For instance, Rosette and Livingston (2012) found that while Black women (compared to Black men, White women, and White men) were penalized more harshly when associated with corporate failure, they were evaluated comparably to White women and Black men under the context of corporate success. In addition, previous research illustrates that people perceived incongruent with leader qualities are expected to fail and are evaluated more negatively when associated with poor firm performance (e.g., Brescoll, Dawson, \& Uhlmann, 2010).

Results illustrated that attributions of responsibility significantly predicted leader and organization perception variables (path b). However, I interpret these results with caution given the significant correlations between attributions of responsibility and the outcome variables (Table 1). Nevertheless, this significant relationship is somewhat supportive of previous research. On the one hand this finding is supported by literature suggesting that inference-based processes are crucial psychological processes that impact 
leader perceptions (Harvey et al., 2014; Martinko, Harvey, \& Dasborough, 2011). On the other hand, previous research suggests that people are motivated to make internal, rather than external, attributions to explain behavior that has a negative outcome (e.g., Jones \& Nisbett, 1987; Ross, 1977; Vignovic \& Thompson, 2010). Nevertheless, I found that leaders associated with diversity-related errors elicited more lenient attributions of responsibility compared to leaders not associated with any error. This result conflicts with this previous work suggesting that participants make stronger internal attributions in response to negative events. However, more recent research has demonstrated that people make both internal and external attributions of blame towards stakeholders involved in the Deepwater Horizon Oil Spill (Kessler et al., 2017; Martinko, Harvey, \& Dasborough, 2011). Therefore, the fact that attributions of responsibility predicted organization perceptions, indicating the use of external attributions, has not been thoroughly examined in the organization literature. Likewise, recent research has failed to rigorously support the claim that attributions are more salient in response to negative events specifically.

\section{Theoretical and practical implications}

Despite the lack of support for the influence of race, gender, and corporate error on leader evaluations, this research brings a number of theoretical and practical contributions, with relevance to a burgeoning area of research examining factors that impact the evaluations of individuals with multiple stigmatized identities in leadership roles (Richardson \& Loubier, 2008; Rosette et al., 2016; Sawyer, Salter, \& Thoroughgood, 2013). 
In a society with an increasingly diverse workforce, it is crucial to understand factors that may hinder the success of minorities as they ascend the corporate ladder and assume executive positions. This research contributes to leadership and diversity research, which maintains that two competing theories — double jeopardy and intersectional invisibility — predict the evaluations of leader with stigmatizing identities. By providing support to neither the double jeopardy hypothesis nor the intersectional invisibility hypothesis, this study indicates that other factors may impact the perception of minority leaders as a function of firm performance. This seems especially important as the literature has yet to reconcile this mixed understanding of the intersection of race and gender in leadership research. Additionally, this research can also contribute to processing theories of leadership, involving inference- and reference-based processing. Research on the inference-based framework provides evidence that leaders will be evaluated negatively when observed in a context of organizational failure (Meindl, 1995). Given the support for Hypothesis 1, in which leaders associated with a corporate error were evaluated more negatively compared to leaders not associated with an error, the results provide support for the inference-based processing system. Research on referencebased processing suggests that group-based stereotypes perceived as incongruent with prototypical leadership qualities lead atypical leaders to be evaluated more negatively. However, this study did not provide support for this reference-based processing given the non-significant interaction between CEO race and gender on leader outcomes. 
The results from this study also supply direct implications for practice. Managers and other organizational stakeholders should constantly work to understand how racial and gender identities can be utilized to stigmatize employees. However, additional stigmatizing identities (e.g., sexual orientation, body size, religion, disability) as well as the intersection of multiple stigmatized identities should be addressed and discussed among managers. In addition, managers should determine whether their organizational practices (e.g., hiring, promotion, and retention decisions) are biased against promoting minorities, and altering these practices to consider stigmatized groups beyond racial minorities and women. Stakeholders also need to be made aware of attribution-based biases that can influence performance appraisals of stigmatized groups. In terms of perceiving top-level executives specifically, organizations should focus on performance metrics and outcomes that can be accurately directed to the leader (e.g., commissions, turnover, market performance).

Furthermore, corporate errors are often very complex and delicate issues that must be handled carefully by organizations. When organizational goals are not met or when corporate errors spread into the public domain, leaders must clearly and judiciously communicate to coworkers and lay people. Although this study did not reveal prejudicial judgments on the basis of race and gender, the fact that previous research demonstrates that leaders with subordinate identities face harsher penalties for organization errors suggests that minority leaders may need to be exceptionally mindful when working through poor performance or corporate failures (Rosette \& Livingston, 2012). On the flip 
side, managers and coworkers must also work diligently to understand their own genuine prejudice and biases towards minority leaders and take steps to restructure their attitudes and behaviors to ensure equitable evaluation, especially across varying contexts.

\section{Limitations and directions for future research}

While this study may present several implications to theory and practice, it does also present various limitations. The results from the current study must be interpreted with caution given the null findings, which suggesting that race and gender do not contribute to any differences in the evaluation of leaders. In addition, reducing the number of outcome variables may reduce the risk of multicollinearity. Furthermore, a closer look into stock market responses to corporate scandals (e.g., stock drop following the United airlines incident; Reklaitis, 2017; Shen, 2017) may shed light on differential stock penalties for companies led by minorities or women compared to those led by typical leaders.

In addition, several components of the methodological approach may have contributed to the lack of significant findings. As noted briefly in the above discussion, the website manipulation paradigm may not have provided enough information for participants to justify expressing prejudice. Future work should address this by using multiple and different methodologies, such as archival or stock market data. Additionally, there was a concern of participant attention within these data. Three attention checks were included throughout the survey, and a majority of participants failed to correctly 
answer these items ${ }^{2}$. The potential inattention of participants could have also contributed to the null findings. Nevertheless, a deeper exploration into the results from this experiment may reveal subtle ways participants may have expressed prejudicial evaluations on the basis of leader race and gender. For instance, the leader attributes variables was a measure that included four different dimensions - warmth, competence, morality, and general leader qualities — which can be isolated and used to examine within-subjects trends that may shed light on prejudicial responding. For, it would be important to know whether participants who evaluated Black leaders as low in warmth, and that significantly predicts more evaluations of leader effectiveness and perceived responsibility. In any case, future research should incorporate more subtle measures to investigate covert forms of prejudice expression systematically.

Another limitation is that this study fails to convey a similar long-term, historical relationships people may have with organizations. Examples of corporate errors currently permeate business media coverage and public responses to these incidents result in protests, boycotts, and defamation not only of the corporation but also leaders within that company (e.g., McLaughlin, 2018; Menegus, 2018; Piepenbring, 2018). For instance, after news that two Black men were arrested in a Philadelphia Starbucks, widespread outrage and boycotts of Starbucks ensued. By creating ostensible websites of CEO

\footnotetext{
${ }^{2}$ The sample included in the analyses reported in the manuscript included all participants, regardless of their responses on attention checks. I conducted the same analyses with participants who passed 2 out of the 3 attention checks $(n=134)$, and found similar nonsignificant results. Thus, I retained my analyses with the full sample $(N=394)$.
} 
responses to real corporate error, the design of this study was an effort to replicate the psychological processes that underscore public responses to corporate errors. Although I developed error scenarios based on errors published in business media news coverage, the hypothetical, role-playing paradigm of this study is limited in mirroring the psychological processes activated when leaders of large U.S. corporations are associated with a scandal. An example of this limitation can be made apparent through the response following the United Airlines. Many members of the public have a historical relationship of United by utilizing their service or having pre-existing opinions of United compared to other airline companies. The reactions towards United airlines (as a company) and towards the CEO may have been exacerbated by one's personal history with United, regardless of the people involved in the incident. Future research should continue exploring ways to replicate with historical embeddedness between members of the public and large national companies to more thoroughly understand the psychological factors contributing to such negative affective responses.

Additionally, a limitation of this research is the targeted focus on attributional processes that may (or may not) primarily explain potential differential leader evaluations. However, I did not capture a thorough understanding of how participants crafted their decisions. Research on policy capturing may inform future avenues of research to develop methods to more fully understand how participants are justifying their responses. Derived from probabilistic functionalism theory (Brunswick, 1955), the policy-capturing methodological approach suggests that experimental variables must be 
structured to mirror the true relationships in the environment being studied. According to Rotundo and Sackett (2002), the policy-capturing statistical technique provides a useful tool to examine the ways perceivers use information to produce a judgment or form an evaluation.

The policy-capturing approach has proven valuable for organizational research. In one study, York (1989) examined how university equal employment officers made evaluative judgments on potential sexual harassment cases, using a policy-capturing approach. Through this method, York (1989) revealed important information cues for EEOC experts when making decisions about whether or not a situation is sexual harassment. In another study, Rotundo and Sackett (2002) utilized a policy-capturing approach to examine the impact of different forms of performance (e.g., task, citizenship) on global ratings of performance for managers. Given that the decision-making behaviors of participants were crucial to my predictions and findings this methodological approach may prove to be promising in future research.

Certainly, other explanatory factors exist that may be useful in examining how perceptions of leaders shift as a function of the context of successful versus faulty performance. As such, future research should explore additional factors that may significantly contribute to an individual's prejudicial response towards minority leaders. Future research should also continue exploring different negative and positive contexts in which leaders may be evaluated (e.g., receiving awards, promotion/succession). 


\section{Conclusion}

Only in recent years has research on intersectional stigmatized identities, specifically Black women, received widespread attention in psychological research. In spite of this however, a wealth of previous research demonstrates that Black leaders and female leaders are not rated comparably to White leaders and male leaders. Although the results from this study do not provide support for existing research, several limitations in the current study should encourage future research to continue exploring not only how to capture the experiences leaders with stigmatized identities are facing but also how to reduce these experiences so that the underrepresentation of diverse executive becomes an artifact of the past. 
RACE AND GENDER ON CORPORATE ERRORS

Table 1

Inter-item correlations and reliabilities for all study variables $(N=396)$

\begin{tabular}{|c|c|c|c|c|c|c|c|c|c|c|}
\hline Variable & $M$ & $S D$ & 1 & 2 & 3 & 4 & 5 & 6 & 7 & 8 \\
\hline $\begin{array}{l}\text { 1. Leader } \\
\text { attributes }\end{array}$ & 3.40 & 0.84 & (.96) & & & & & & & \\
\hline $\begin{array}{l}\text { 2. Leader } \\
\text { effectiveness }\end{array}$ & 4.52 & 1.69 & $.86^{* * *}$ & (.95) & & & & & & \\
\hline $\begin{array}{l}\text { 3. Leader } \\
\text { response }\end{array}$ & 4.31 & 1.62 & $.83 * * *$ & $.83 * * *$ & $(.91)$ & & & & & \\
\hline 4. Salary & 1.82 & 0.88 & $.52 * * *$ & $.53 * * *$ & $.52 * * *$ & - & & & & \\
\hline 5. Promotion & 3.57 & 1.79 & $.67 * * *$ & $.71 * * *$ & $.67 * * *$ & $.51 * * *$ & - & & & \\
\hline $\begin{array}{l}\text { 6. Behavioral } \\
\text { intentions }\end{array}$ & 3.54 & 1.50 & $.63 * * *$ & $.70 * * *$ & $.65^{* * *}$ & $.56^{* * *}$ & $.64 * * *$ & $(.71)$ & & \\
\hline $\begin{array}{l}\text { 7. Corporate } \\
\text { reputation }\end{array}$ & 4.11 & 1.48 & $.53 * * *$ & $.54 * * *$ & $.50 * * *$ & $.33 * * *$ & $.51 * * *$ & $.60 * * *$ & $(.80)$ & \\
\hline $\begin{array}{l}\text { 8. Attributions of } \\
\text { responsibility }\end{array}$ & 4.33 & 1.49 & $.15^{* *}$ & $.15^{* *}$ & $.13 * *$ & $.15^{* *}$ & .09 & $.26 * * *$ & $-.19 * * *$ & (.91) \\
\hline
\end{tabular}

Note: Cronbach's alpha reliability values are displayed on the diagonal. $M=$ mean, $S D=$ standard deviation.

$* * p<.01$

$* * * p<.001$ 
RACE AND GENDER ON CORPORATE ERRORS

Table 2

Means and standard deviations for all study variables, by CEO race x gender

\begin{tabular}{lcccccccc}
\hline & \multicolumn{2}{c}{$\begin{array}{c}\text { Black women } \\
(\mathrm{n}=91)\end{array}$} & \multicolumn{2}{c}{$\begin{array}{c}\text { Black men } \\
(\mathrm{n}=101)\end{array}$} & \multicolumn{2}{c}{$\begin{array}{c}\text { White women } \\
(\mathrm{n}=95)\end{array}$} & \multicolumn{2}{c}{$\begin{array}{c}\text { White men } \\
(n=101)\end{array}$} \\
\cline { 2 - 10 } Variable & $M$ & $S D$ & $M$ & $S D$ & $M$ & $S D$ & $M$ & $S D$ \\
\hline Leader attributes & 3.44 & 0.76 & 3.44 & 0.82 & 3.41 & 0.91 & 3.28 & 0.88 \\
Leader effectiveness & 4.50 & 1.68 & 4.61 & 1.59 & 4.62 & 1.77 & 4.32 & 1.75 \\
Leader response & 4.27 & 1.50 & 4.40 & 1.57 & 4.34 & 1.76 & 4.19 & 1.69 \\
Salary & 1.83 & 0.88 & 1.86 & 0.87 & 1.85 & 0.92 & 1.77 & 0.84 \\
Promotion & 3.69 & 1.78 & 3.75 & 1.86 & 3.56 & 1.73 & 3.27 & 1.76 \\
Behavioral intentions & 3.44 & 1.43 & 3.66 & 1.57 & 3.52 & 1.47 & 3.55 & 1.56 \\
Corporate reputation & 4.13 & 1.47 & 4.20 & 1.44 & 4.07 & 1.52 & 3.98 & 1.51 \\
Attributions of & & & & & & & & \\
responsibility & 4.22 & 1.46 & 4.38 & 1.52 & 4.4 & 1.53 & 4.42 & 1.42 \\
\hline
\end{tabular}

Note: $M=$ mean, $S D=$ standard deviation. 
Table 3

Means and standard deviations for Black female CEOs across all study variables, by error

\begin{tabular}{lcccccc}
\hline & \multicolumn{2}{c}{$\begin{array}{c}\text { Control } \\
(n=30)\end{array}$} & \multicolumn{2}{c}{$\begin{array}{c}\text { Diversity } \\
(n=28)\end{array}$} & \multicolumn{2}{c}{$\begin{array}{c}\text { Non-diversity } \\
(n=33)\end{array}$} \\
\cline { 2 - 7 } Variable & $M$ & $S D$ & $M$ & $S D$ & $M$ & $S D$ \\
\hline Leader attributes & 3.76 & 0.80 & 3.47 & 0.58 & 3.11 & 0.76 \\
Leader effectiveness & 5.34 & 1.55 & 4.41 & 1.44 & 3.80 & 1.67 \\
Leader response & 5.13 & 1.21 & 4.13 & 1.39 & 3.61 & 1.49 \\
Salary & 1.99 & 0.81 & 1.93 & 0.76 & 1.59 & 0.99 \\
$\begin{array}{l}\text { Promotion } \\
\text { Behavioral }\end{array}$ & 4.73 & 1.55 & 3.61 & 1.37 & 2.82 & 1.83 \\
intentions & 4.34 & 1.06 & 2.95 & 1.37 & 3.44 & 1.43 \\
$\begin{array}{l}\text { Corporate reputation } \\
\begin{array}{l}\text { Attributions of } \\
\text { responsibility }\end{array}\end{array}$ & 5.16 & 1.23 & 3.81 & 1.24 & 3.47 & 1.35 \\
\hline
\end{tabular}

Note: $M=$ mean, $S D=$ standard deviation. 
RACE AND GENDER ON CORPORATE ERRORS

Table 4

Means and standard deviations for Black male CEOs across all study variables, by error

\begin{tabular}{lcccccc}
\hline & \multicolumn{2}{c}{$\begin{array}{c}\text { Control } \\
(n=34)\end{array}$} & \multicolumn{2}{c}{$\begin{array}{c}\text { Diversity } \\
(n=35)\end{array}$} & \multicolumn{2}{c}{$\begin{array}{c}\text { Non-diversity } \\
(n=32)\end{array}$} \\
\cline { 2 - 7 } Variable & $M$ & $S D$ & $M$ & $S D$ & $M$ & $S D$ \\
\hline Leader attributes & 3.97 & 0.72 & 3.19 & 0.89 & 3.17 & 0.57 \\
Leader effectiveness & 5.55 & 1.03 & 4.28 & 1.54 & 3.97 & 1.71 \\
Leader response & 5.13 & 1.12 & 4.05 & 1.64 & 4.00 & 1.68 \\
Salary & 2.18 & 0.69 & 1.67 & 0.91 & 1.71 & 0.93 \\
Promotion & 4.91 & 1.38 & 3.46 & 1.74 & 2.84 & 1.83 \\
$\begin{array}{l}\text { Behavioral } \\
\text { intentions }\end{array}$ & 4.86 & 1.13 & 3.13 & 1.35 & 2.95 & 1.47 \\
$\begin{array}{l}\text { Corporate reputation } \\
\begin{array}{l}\text { Attributions of } \\
\text { responsibility }\end{array}\end{array}$ & 5.16 & 1.44 & 3.75 & 1.25 & 3.68 & 1.12 \\
\hline
\end{tabular}

Note: $M=$ mean, $S D=$ standard deviation. 
RACE AND GENDER ON CORPORATE ERRORS

Table 5

Means and standard deviations for White female CEOs across all study variables, by error

\begin{tabular}{lcccccc}
\hline & \multicolumn{2}{c}{$\begin{array}{c}\text { Control } \\
(n=34)\end{array}$} & \multicolumn{2}{c}{$\begin{array}{c}\text { Diversity } \\
(n=32)\end{array}$} & \multicolumn{2}{c}{$\begin{array}{c}\text { Non-diversity } \\
(n=29)\end{array}$} \\
\cline { 2 - 7 } Variable & $M$ & $S D$ & $M$ & $S D$ & $M$ & $S D$ \\
\hline Leader attributes & 3.88 & 0.57 & 3.26 & 0.94 & 3.03 & 0.98 \\
Leader effectiveness & 5.69 & 0.97 & 4.11 & 1.86 & 3.92 & 1.84 \\
Leader response & 5.19 & 1.04 & 4.13 & 1.85 & 3.58 & 1.95 \\
Salary & 1.85 & 0.81 & 1.77 & 0.94 & 1.92 & 1.04 \\
Promotion & 4.50 & 1.26 & 3.09 & 1.79 & 2.97 & 1.72 \\
Behavioral intentions & 4.32 & 1.21 & 2.86 & 1.49 & 3.29 & 1.34 \\
Corporate reputation & 5.02 & 1.22 & 3.45 & 1.49 & 3.63 & 1.34 \\
Attributions of & 4.68 & 1.12 & 4.03 & 1.77 & 4.47 & 1.61 \\
responsibility & & & & & &
\end{tabular}

Note: $M=$ mean, $S D=$ standard deviation. 
RACE AND GENDER ON CORPORATE ERRORS

Table 6

Means and standard deviations for White male CEOs across all study variables, by error

\begin{tabular}{lcccccc}
\hline & \multicolumn{2}{c}{$\begin{array}{c}\text { Control } \\
(n=35)\end{array}$} & \multicolumn{2}{c}{$\begin{array}{c}\text { Diversity } \\
(n=32)\end{array}$} & \multicolumn{2}{c}{$\begin{array}{c}\text { Non-diversity } \\
(n=34)\end{array}$} \\
\cline { 2 - 7 } Variable & $M$ & $S D$ & $M$ & $S D$ & $M$ & $S D$ \\
\hline Leader attributes & 3.85 & 0.57 & 3.14 & 0.96 & 2.82 & 0.75 \\
Leader effectiveness & 5.41 & 0.88 & 4.04 & 1.88 & 3.46 & 1.75 \\
Leader response & 5.14 & 0.92 & 4.00 & 1.94 & 3.38 & 1.60 \\
Salary & 2.20 & 0.63 & 1.57 & 0.79 & 1.51 & 0.93 \\
Promotion & 4.26 & 1.27 & 3.16 & 1.69 & 2.35 & 1.77 \\
Behavioral intentions & 4.64 & 0.93 & 3.33 & 1.50 & 2.64 & 1.48 \\
Corporate reputation & 4.80 & 1.10 & 4.00 & 1.59 & 3.11 & 1.33 \\
Attributions of & & & & & & \\
responsibility & 4.63 & 4.03 & 4.01 & 1.72 & 4.59 & 1.39 \\
\hline
\end{tabular}

Note: $M=$ mean, $S D=$ standard deviation. 
Table 7

MANOVA tests of significance for main effect of corporate error (H1).

\begin{tabular}{|c|c|c|c|c|}
\hline Variable & $F$ & $p$ & $\eta^{2}$ & $M(S D)$ \\
\hline & & & & Control: 3.87 (0.67) \\
\hline \multirow[t]{2}{*}{ Leader attributes } & $\begin{array}{c}40.90 \\
(2,376)\end{array}$ & $<.001$ & .18 & Diversity: 3.23 (0.86) \\
\hline & & & & Non-diversity: 3.03 (0.77) \\
\hline \multirow{3}{*}{ Leader effectiveness } & & & & Control: 5.50 (1.12) \\
\hline & $\begin{array}{c}43.73 \\
(2,376)\end{array}$ & $<.001$ & .19 & Diversity: 4.21 (1.66) \\
\hline & & & & Non-diversity: 3.79 (1.73) \\
\hline \multirow{3}{*}{ Leader response } & & & & Control: 5.15 (1.06) \\
\hline & $\begin{array}{c}34.13 \\
(2,376)\end{array}$ & $<.001$ & .15 & Diversity: 4.08 (1.70) \\
\hline & & & & Non-diversity: 3.64 (1.67) \\
\hline \multirow{3}{*}{ Salary } & & & & Control: 2.05 (0.74) \\
\hline & $\begin{array}{c}7.05 \\
(2,376)\end{array}$ & .001 & .04 & Diversity: 1.74 (0.86) \\
\hline & & & & Non-diversity: 1.69 (0.97) \\
\hline \multirow{3}{*}{ Promotion } & & & & Control: 4.60 (1.37) \\
\hline & $\begin{array}{c}45.16 \\
(2,376)\end{array}$ & $<.001$ & .19 & Diversity: 3.33 (1.67) \\
\hline & & & & Non-diversity: 2.75 (1.78) \\
\hline \multirow{3}{*}{ Behavioral intentions } & & & & Control: 4.54 (1.10) \\
\hline & $\begin{array}{c}57.41 \\
(2,376)\end{array}$ & $<.001$ & .23 & Diversity: 3.07 (1.42) \\
\hline & & & & Non-diversity: 2.98 (1.43) \\
\hline \multirow{3}{*}{ Corporate reputation } & & & & Control: 5.04 (1.25) \\
\hline & $\begin{array}{c}52.64 \\
(2,376)\end{array}$ & $<.001$ & .22 & Diversity: 3.75 (1.41) \\
\hline & & & & Non-diversity: 3.47 (1.31) \\
\hline
\end{tabular}


RACE AND GENDER ON CORPORATE ERRORS

Table 8

Bootstrap (10,000 samples) mediation analyses for the effect of CEO identity (race $x$ gender) on leader perceptions through attributions of responsibility $(N=396)$

\begin{tabular}{|c|c|c|c|c|c|c|c|}
\hline \multirow[b]{2}{*}{$\begin{array}{l}\text { CEO } \\
\text { Identity }\end{array}$} & \multirow[b]{2}{*}{ Outcome } & \multirow[b]{2}{*}{ Est. MX } & \multirow[b]{2}{*}{ Est. YM } & \multirow[b]{2}{*}{$\begin{array}{l}\text { Direct } \\
\text { Effect }\end{array}$} & \multirow[b]{2}{*}{$\begin{array}{l}\text { Indirect } \\
\text { Effect }\end{array}$} & \multicolumn{2}{|c|}{ Indirect Effect } \\
\hline & & & & & & LCL & UCL \\
\hline \multirow[t]{5}{*}{$\begin{array}{l}\text { Black } \\
\text { women }\end{array}$} & $\begin{array}{l}\text { Leader } \\
\text { attributes }\end{array}$ & $\begin{array}{c}4.15 \\
(.15)^{* * *}\end{array}$ & $\begin{array}{c}0.09 \\
(.03)^{* *}\end{array}$ & $\begin{array}{c}3.08 \\
(.15)^{* * *}\end{array}$ & $3.44(.09)^{* * *}$ & 3.27 & 3.61 \\
\hline & $\begin{array}{l}\text { Leader } \\
\text { effectiveness }\end{array}$ & & $0.17(.06)^{* *}$ & $\begin{array}{c}3.80 \\
(.29)^{* * *}\end{array}$ & $4.50(.17)^{* * *}$ & 4.16 & 4.84 \\
\hline & $\begin{array}{l}\text { Leader } \\
\text { response }\end{array}$ & & $0.14(.05)^{*}$ & $\begin{array}{c}3.72 \\
(.28)^{* * *}\end{array}$ & $4.30(.17)^{* * *}$ & 3.97 & 4.63 \\
\hline & Salary ${ }^{a}$ & $4.22(.16)$ & $0.09(.03)^{* *}$ & $\begin{array}{c}1.46 \\
(.16)^{* * *}\end{array}$ & $1.83(.09)^{* * *}$ & 1.65 & 2.01 \\
\hline & Promotion & & $0.12(.06)^{*}$ & $\begin{array}{c}3.23 \\
(.31)^{* * *}\end{array}$ & $3.71(.18)^{* * *}$ & 3.35 & 4.08 \\
\hline \multirow[t]{5}{*}{ Black men } & $\begin{array}{l}\text { Leader } \\
\text { attributes }\end{array}$ & $0.21(.22)$ & $0.09(.03)^{* *}$ & $-0.04(.12)$ & $-0.02(.12)$ & -0.26 & 0.22 \\
\hline & $\begin{array}{l}\text { Leader } \\
\text { effectiveness }\end{array}$ & & $0.17(.06)^{* *}$ & $0.08(.24)$ & $0.11(.24)$ & -0.37 & 0.59 \\
\hline & $\begin{array}{l}\text { Leader } \\
\text { response }\end{array}$ & & $0.14(.05)^{*}$ & $0.01(.23)$ & $0.04(.24)$ & -0.42 & 0.50 \\
\hline & Salary $^{\mathrm{a}}$ & $0.18(.22)$ & $0.09(.03)^{* *}$ & $0.01(.13)$ & $0.02(.13)$ & -0.23 & 0.27 \\
\hline & Promotion & & $0.12(.06)^{*}$ & $-0.20(.26)$ & $-0.18(.26)$ & -0.69 & 0.33 \\
\hline
\end{tabular}


RACE AND GENDER ON CORPORATE ERRORS

\begin{tabular}{|c|c|c|c|c|c|c|c|}
\hline \multirow[b]{2}{*}{$\begin{array}{c}\text { CEO } \\
\text { Identity }\end{array}$} & \multirow[b]{2}{*}{ Outcome } & \multirow[b]{2}{*}{ Est. MX } & \multirow[b]{2}{*}{ Est. YM } & \multirow[b]{2}{*}{$\begin{array}{l}\text { Direct } \\
\text { Effect }\end{array}$} & \multirow[b]{2}{*}{$\begin{array}{l}\text { Indirect } \\
\text { Effect }\end{array}$} & \multicolumn{2}{|c|}{ Indirect Effect } \\
\hline & & & & & & LCL & UCL \\
\hline \multirow[t]{5}{*}{$\begin{array}{l}\text { White } \\
\text { women }\end{array}$} & $\begin{array}{l}\text { Leader } \\
\text { attributes }\end{array}$ & $0.24(.21)$ & $0.09(.03)^{* *}$ & $0.01(.12)$ & $0.03(.12)$ & -0.21 & 0.26 \\
\hline & $\begin{array}{l}\text { Leader } \\
\text { effectiveness }\end{array}$ & & $0.17(.06)^{* *}$ & $0.10(.24)$ & $0.14(.24)$ & -0.33 & 0.62 \\
\hline & $\begin{array}{l}\text { Leader } \\
\text { response }\end{array}$ & & $0.14(.05)^{*}$ & $0.08(.23)$ & $0.11(.23)$ & -0.35 & 0.57 \\
\hline & Salary $^{\mathrm{a}}$ & $0.16(.21)$ & $0.09(.03)^{* *}$ & $0.14(.13)$ & $0.03(.13)$ & -0.22 & 0.28 \\
\hline & Promotion & & $0.12(.06)^{*}$ & $0.03(.25)$ & $0.05(.25)$ & -0.45 & 0.56 \\
\hline \multirow[t]{5}{*}{ White men } & $\begin{array}{l}\text { Leader } \\
\text { attributes }\end{array}$ & $0.26(.21)$ & $0.09(.03)^{* *}$ & $-0.19(.12)$ & $-0.17(.12)$ & -0.41 & 0.07 \\
\hline & $\begin{array}{l}\text { Leader } \\
\text { effectiveness }\end{array}$ & & $0.17(.06)^{* *}$ & $-0.24(.24)$ & $-0.20(.24)$ & -0.68 & 0.28 \\
\hline & $\begin{array}{l}\text { Leader } \\
\text { response }\end{array}$ & & $0.14(.05)^{*}$ & $-0.16(.23)$ & $-0.13(.23)$ & -0.59 & 0.33 \\
\hline & Salary $^{a}$ & $0.20(.21)$ & $0.09(.03)^{* *}$ & $-0.08(.13)$ & $-0.06(.13)$ & -0.22 & 0.28 \\
\hline & Promotion & & $0.12(.06)^{*}$ & $-0.49(.26)$ & $-0.46(.26)$ & -0.96 & 0.04 \\
\hline
\end{tabular}

Note: Est. MX = bootstrapped estimate of the path from CEO identity to attributions of responsibility. Est. YM = bootstrapped estimate of path from attributions of responsibility to leader perception outcomes. $\mathrm{LCL}=$ lower confidence limit. $\mathrm{UCL}=$ upper confidence limit. The estimates of Est. MX are the same across most outcomes;

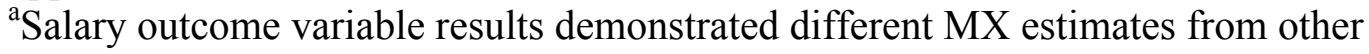
outcome variables due to smaller sample size $(n=388)$. Standard errors of the bootstrapped estimates appear in parentheses. ${ }^{*} p<.05 .{ }^{* *} p<.01 . * * * p<.001$. 
Table 9

Bootstrap (10,000 samples) mediation analyses for the effect of CEO identity (race $x$ gender) on organization perceptions through attributions of responsibility $(N=396)$

\begin{tabular}{|c|c|c|c|c|c|c|c|}
\hline \multirow[b]{2}{*}{$\begin{array}{l}\text { CEO } \\
\text { identity }\end{array}$} & \multirow[b]{2}{*}{ Outcome } & \multirow[b]{2}{*}{ Est. MX } & \multirow[b]{2}{*}{ Est. YM } & \multirow[b]{2}{*}{$\begin{array}{l}\text { Direct } \\
\text { Effect }\end{array}$} & \multirow[b]{2}{*}{$\begin{array}{l}\text { Indirect } \\
\text { Effect }\end{array}$} & \multicolumn{2}{|c|}{ Indirect Effect } \\
\hline & & & & & & LCL & UCL \\
\hline \multirow[t]{2}{*}{$\begin{array}{l}\text { Black } \\
\text { women }\end{array}$} & $\begin{array}{l}\text { Behavioral } \\
\text { intentions }\end{array}$ & \multirow[b]{2}{*}{$4.15(.15)^{* * *}$} & $\begin{array}{c}0.26 \\
(.05)^{* * *}\end{array}$ & $2.32(.25)$ & $3.40(.16)$ & 3.10 & 3.71 \\
\hline & $\begin{array}{l}\text { Corporate } \\
\text { reputation }\end{array}$ & & $\begin{array}{c}-0.19 \\
(.05)^{* * *}\end{array}$ & $4.91(.25)$ & $4.12(.15)$ & 3.82 & 4.42 \\
\hline \multirow[t]{2}{*}{ Black men } & $\begin{array}{l}\text { Behavioral } \\
\text { intentions }\end{array}$ & \multirow{2}{*}{$0.21(.22)$} & $\begin{array}{c}0.26 \\
(.05)^{* * *}\end{array}$ & $0.07(.21)$ & $0.12(.22)$ & -0.31 & 0.55 \\
\hline & $\begin{array}{l}\text { Corporate } \\
\text { reputation }\end{array}$ & & $\begin{array}{c}-0.19 \\
(.05)^{* * *}\end{array}$ & $0.02(.21)$ & $-0.02(.15)$ & -0.44 & 0.40 \\
\hline \multirow[t]{2}{*}{$\begin{array}{l}\text { White } \\
\text { women }\end{array}$} & $\begin{array}{l}\text { Behavioral } \\
\text { intentions }\end{array}$ & \multirow{2}{*}{$0.24(.21)$} & $\begin{array}{c}0.26 \\
(.05)^{* * *}\end{array}$ & $0.19(.21)$ & $0.26(.21)$ & -0.17 & 0.68 \\
\hline & $\begin{array}{l}\text { Corporate } \\
\text { reputation }\end{array}$ & & $\begin{array}{c}-0.19 \\
(.05)^{* * *}\end{array}$ & $0.14(.21)$ & $0.10(.21)$ & -0.32 & 0.51 \\
\hline \multirow[t]{2}{*}{ White men } & $\begin{array}{l}\text { Behavioral } \\
\text { intentions }\end{array}$ & \multirow{2}{*}{$0.26(.21)$} & $\begin{array}{c}0.26 \\
(.05)^{* * *}\end{array}$ & $0.07(.21)$ & $0.14(.22)$ & -0.28 & 0.56 \\
\hline & $\begin{array}{l}\text { Corporate } \\
\text { reputation }\end{array}$ & & $\begin{array}{c}-0.19 \\
(.05)^{* * *}\end{array}$ & $-0.08(.21)$ & $-0.13(.21)$ & -0.55 & -0.29 \\
\hline
\end{tabular}

Note: Est. $\mathrm{MX}=$ bootstrapped estimate of the path from CEO identity to attributions of responsibility. Est. YM = bootstrapped estimate of path from attributions of responsibility to organization perception outcomes. LCL $=$ lower confidence limit. UCL $=$ upper confidence limit. The estimates of Est. MX are the same across outcomes. Standard errors of the bootstrapped estimates appear in parentheses. $* * * p<.001$. 
Table 10

Bootstrapped (10,000 samples) moderated mediation analyses for the effect of corporate error context on the influence of CEO identity (race $x$ gender) on leader perceptions through attributions of responsibility $(N=396)$

\begin{tabular}{|c|c|c|c|c|c|c|c|c|}
\hline \multirow[b]{2}{*}{$\begin{array}{l}\text { CEO } \\
\text { identity }\end{array}$} & \multirow[b]{2}{*}{ Outcome } & \multirow[b]{2}{*}{ Est. MX } & \multirow[b]{2}{*}{ Est. YM } & \multirow[b]{2}{*}{$\begin{array}{l}\text { Direct } \\
\text { Effect }\end{array}$} & \multirow[b]{2}{*}{ Error } & \multirow[b]{2}{*}{$\begin{array}{l}\text { Indirect } \\
\text { Effect }\end{array}$} & \multicolumn{2}{|c|}{$\begin{array}{l}\text { Indirect } \\
\text { Effect }\end{array}$} \\
\hline & & & & & & & LCL & UCL \\
\hline \multirow[t]{15}{*}{$\begin{array}{l}\text { Black } \\
\text { men }\end{array}$} & $\begin{array}{l}\text { Leader } \\
\text { attributes }\end{array}$ & $0.21(.36)$ & $\begin{array}{c}0.09 \\
(.03)^{* *}\end{array}$ & $-0.04(.12)$ & Control & $0.02(.03)$ & -0.04 & 0.08 \\
\hline & & & & & Diversity & $0.06(.04)$ & -0.02 & 0.15 \\
\hline & & & & & $\begin{array}{c}\text { Non- } \\
\text { diversity }\end{array}$ & $-0.01(.03)$ & -0.09 & 0.05 \\
\hline & $\begin{array}{l}\text { Leader } \\
\text { effectiveness }\end{array}$ & & $\begin{array}{c}0.17 \\
(.06)^{* *}\end{array}$ & $0.08(.24)$ & Control & $0.04(.06)$ & -0.08 & 0.16 \\
\hline & & & & & Diversity & $0.11(.08)$ & -0.03 & 0.29 \\
\hline & & & & & $\begin{array}{c}\text { Non- } \\
\text { diversity }\end{array}$ & $-0.02(.07)$ & -0.17 & 0.10 \\
\hline & $\begin{array}{l}\text { Leader } \\
\text { response }\end{array}$ & & $0.14(.05)^{*}$ & $0.01(.23)$ & Control & $0.03(.05)$ & -0.06 & 0.14 \\
\hline & & & & & Diversity & $0.09(.07)$ & -0.03 & 0.25 \\
\hline & & & & & $\begin{array}{c}\text { Non- } \\
\text { diversity }\end{array}$ & $-0.02(.06)$ & -0.15 & 0.09 \\
\hline & Salary & & $\begin{array}{c}0.09 \\
(.03)^{* *}\end{array}$ & $\begin{array}{l}0.004 \\
(.13)\end{array}$ & Control & $0.02(.03)$ & -0.04 & 0.08 \\
\hline & & & & & Diversity & $0.05(.04)$ & -0.02 & 0.14 \\
\hline & & & & & $\begin{array}{c}\text { Non- } \\
\text { diversity }\end{array}$ & $-0.02(.03)$ & -0.09 & 0.05 \\
\hline & Promotion & & $0.12(.06)$ & $-0.20(.26)$ & Control & $0.02(.04)$ & -0.05 & 0.12 \\
\hline & & & & & Diversity & $0.07(.07)$ & -0.03 & 0.24 \\
\hline & & & & & $\begin{array}{c}\text { Non- } \\
\text { diversity }\end{array}$ & $-0.02(.05)$ & -0.13 & 0.08 \\
\hline
\end{tabular}


RACE AND GENDER ON CORPORATE ERRORS

\begin{tabular}{|c|c|c|c|c|c|c|c|c|}
\hline \multirow[b]{2}{*}{$\begin{array}{l}\text { CEO } \\
\text { identity }\end{array}$} & \multirow[b]{2}{*}{ Outcome } & \multirow[b]{2}{*}{ Est. MX } & \multirow[b]{2}{*}{$\begin{array}{l}\text { Est. } \\
\text { YM }\end{array}$} & \multirow[b]{2}{*}{$\begin{array}{l}\text { Direct } \\
\text { Effect }\end{array}$} & \multirow[b]{2}{*}{ Error } & \multirow[b]{2}{*}{$\begin{array}{l}\text { Indirect } \\
\text { Effect }\end{array}$} & \multicolumn{2}{|c|}{$\begin{array}{l}\text { Indirect } \\
\text { Effect }\end{array}$} \\
\hline & & & & & & & LCL & UCL \\
\hline \multirow[t]{15}{*}{$\begin{array}{l}\text { White } \\
\text { women }\end{array}$} & $\begin{array}{l}\text { Leader } \\
\text { attributes }\end{array}$ & $\begin{array}{l}0.38 \\
(.36)\end{array}$ & $\begin{array}{c}0.09 \\
(.03)^{* *}\end{array}$ & $\begin{array}{l}0.004 \\
(.12)\end{array}$ & Control & $0.03(.03)$ & -0.02 & 0.10 \\
\hline & & & & & Diversity & $0.04(.04)$ & -0.03 & 0.13 \\
\hline & & & & & $\begin{array}{c}\text { Non- } \\
\text { diversity }\end{array}$ & $\begin{array}{c}-0.001 \\
(.03)\end{array}$ & -0.06 & 0.06 \\
\hline & $\begin{array}{l}\text { Leader } \\
\text { effectiveness }\end{array}$ & & $\begin{array}{c}0.17 \\
(.06)^{* *}\end{array}$ & $0.10(.24)$ & Control & $0.06(.06)$ & -0.04 & 0.20 \\
\hline & & & & & Diversity & $0.07(.08)$ & -0.07 & 0.25 \\
\hline & & & & & $\begin{array}{c}\text { Non- } \\
\text { diversity }\end{array}$ & $\begin{array}{c}-0.002 \\
(.06)\end{array}$ & -0.13 & 0.11 \\
\hline & $\begin{array}{l}\text { Leader } \\
\text { response }\end{array}$ & & $\begin{array}{c}0.14 \\
(.05)^{*}\end{array}$ & $0.08(.23)$ & Control & $0.05(.05)$ & -0.04 & 0.17 \\
\hline & & & & & Diversity & $0.06(.07)$ & -0.06 & 0.21 \\
\hline & & & & & $\begin{array}{c}\text { Non- } \\
\text { diversity }\end{array}$ & $\begin{array}{c}-0.001 \\
(.05)\end{array}$ & -0.10 & 0.10 \\
\hline & Salary & & $\begin{array}{c}0.09 \\
(.03)^{* *}\end{array}$ & $.013(.13)$ & Control & $0.03(.032)$ & -0.02 & 0.10 \\
\hline & & & & & Diversity & $0.03(.04)$ & -0.05 & 0.11 \\
\hline & & & & & $\begin{array}{c}\text { Non- } \\
\text { diversity }\end{array}$ & $-0.01(.03)$ & -0.07 & 0.05 \\
\hline & Promotion & & $\begin{array}{l}0.12 \\
(.06)\end{array}$ & $0.02(.25)$ & Control & $0.04(.05)$ & -0.03 & 0.15 \\
\hline & & & & & Diversity & $0.05(.06)$ & -0.05 & 0.20 \\
\hline & & & & & $\begin{array}{c}\text { Non- } \\
\text { diversity }\end{array}$ & $\begin{array}{c}-0.001 \\
(.04)\end{array}$ & -0.09 & 0.09 \\
\hline
\end{tabular}


RACE AND GENDER ON CORPORATE ERRORS

\begin{tabular}{|c|c|c|c|c|c|c|c|c|}
\hline \multirow[b]{2}{*}{$\begin{array}{l}\text { CEO } \\
\text { identity }\end{array}$} & \multirow[b]{2}{*}{ Outcome } & \multirow[b]{2}{*}{ Est. MX } & \multirow[b]{2}{*}{ Est. YM } & \multirow[b]{2}{*}{$\begin{array}{l}\text { Direct } \\
\text { Effect }\end{array}$} & \multirow[b]{2}{*}{ Error } & \multirow[b]{2}{*}{$\begin{array}{l}\text { Indirect } \\
\text { Effect }\end{array}$} & \multicolumn{2}{|c|}{$\begin{array}{l}\text { Indirect } \\
\text { Effect }\end{array}$} \\
\hline & & & & & & & LCL & UCL \\
\hline \multirow[t]{15}{*}{$\begin{array}{l}\text { White } \\
\text { men }\end{array}$} & $\begin{array}{l}\text { Leader } \\
\text { attributes }\end{array}$ & $\begin{array}{l}0.16 \\
(.36)\end{array}$ & $\begin{array}{c}0.09 \\
(.03)^{* *}\end{array}$ & $\begin{array}{l}-0.19 \\
(.03)\end{array}$ & Control & $0.01(.03)$ & -0.04 & 0.08 \\
\hline & & & & & Diversity & $0.06(.04)$ & -0.02 & 0.15 \\
\hline & & & & & $\begin{array}{c}\text { Non- } \\
\text { diversity }\end{array}$ & $\begin{array}{c}-.0004 \\
(.03)\end{array}$ & -0.06 & 0.06 \\
\hline & $\begin{array}{l}\text { Leader } \\
\text { effectiveness }\end{array}$ & & $\begin{array}{l}0.17 \\
(.06)^{* *}\end{array}$ & $\begin{array}{l}-0.24 \\
(.24)\end{array}$ & Control & $0.03(.06)$ & -0.08 & 0.15 \\
\hline & & & & & Diversity & $0.11(.08)$ & -0.03 & 0.30 \\
\hline & & & & & $\begin{array}{c}\text { Non- } \\
\text { diversity }\end{array}$ & $-.001(.06)$ & -0.12 & 0.12 \\
\hline & $\begin{array}{l}\text { Leader } \\
\text { response }\end{array}$ & & $\begin{array}{l}0.14 \\
(.05)^{*}\end{array}$ & $\begin{array}{l}-0.16 \\
(.23)\end{array}$ & Control & $0.02(.05)$ & -0.07 & 0.12 \\
\hline & & & & & Diversity & $0.09(.07)$ & -0.03 & 0.27 \\
\hline & & & & & $\begin{array}{c}\text { Non- } \\
\text { diversity }\end{array}$ & $\begin{array}{c}-0.001 \\
(.05)\end{array}$ & -0.10 & 0.10 \\
\hline & Salary & & $\begin{array}{c}0.09 \\
(.03)^{* *}\end{array}$ & $\begin{array}{l}-0.08 \\
(.13)\end{array}$ & Control & $0.01(.03)$ & -0.04 & 0.08 \\
\hline & & & & & Diversity & $0.05(.04)$ & -0.03 & 0.14 \\
\hline & & & & & $\begin{array}{c}\text { Non- } \\
\text { diversity }\end{array}$ & $-0.01(.03)$ & -0.07 & 0.05 \\
\hline & Promotion & & $0.12(.06)$ & $\begin{array}{l}-0.49 \\
(.26)\end{array}$ & Control & $0.02(.04)$ & -0.06 & 0.11 \\
\hline & & & & & Diversity & $0.08(.07)$ & -0.03 & 0.24 \\
\hline & & & & & $\begin{array}{c}\text { Non- } \\
\text { diversity }\end{array}$ & $-0.01(.04)$ & -0.09 & 0.09 \\
\hline
\end{tabular}

Note: Est. $\mathrm{MX}=$ bootstrapped estimate of the path from CEO identity to attributions of responsibility. Est. $\mathrm{YM}=$ bootstrapped estimate of path from attributions of responsibility to leader perception outcomes. Indirect Effect $=$ estimates of relative conditional effects of CEO identity on each outcome variable, by corporate error. $\mathrm{LCL}=$ lower confidence limit. $\mathrm{UCL}=$ upper confidence limit. The estimates of Est. MX are the same across outcomes (constant, $b=4.47, S E=.26, p<.001$ ). Standard errors of the bootstrapped estimates appear in parentheses. ${ }^{*} p<.05 .{ }^{* *} p<.01$. 
RACE AND GENDER ON CORPORATE ERRORS

\section{Table 11}

Bootstrapped (10,000 samples) moderated mediation analyses for the effect corporate error context on the relative conditional influence of $\mathrm{CEO}$ identity (race $x$ gender) on leader perceptions through attributions of responsibility $(N=396)$

\begin{tabular}{|c|c|c|c|c|c|c|c|c|}
\hline \multirow[b]{2}{*}{$\begin{array}{l}\text { CEO identity } \\
\text { comparison }\end{array}$} & \multirow[b]{2}{*}{ Outcome } & \multirow[b]{2}{*}{$\begin{array}{l}\text { Est. } \\
\text { MX }\end{array}$} & \multirow[b]{2}{*}{ Est. YM } & \multirow[b]{2}{*}{$\begin{array}{l}\text { Direct } \\
\text { Effect }\end{array}$} & \multirow[b]{2}{*}{ Error } & \multirow[b]{2}{*}{$\begin{array}{l}\text { Indirect } \\
\text { Effect }\end{array}$} & \multicolumn{2}{|c|}{$\begin{array}{l}\text { Indirect } \\
\text { Effect }\end{array}$} \\
\hline & & & & & & & LCL & UCL \\
\hline \multirow[t]{15}{*}{$\begin{array}{c}\text { Black women v. } \\
\text { Black men }\end{array}$} & $\begin{array}{l}\text { Leader } \\
\text { attributes }\end{array}$ & $\begin{array}{l}0.21 \\
(.36)\end{array}$ & $\begin{array}{c}0.09 \\
(.03)^{* *}\end{array}$ & $-0.04(.12)$ & Control & $3.44(.09)$ & 3.27 & 3.61 \\
\hline & & & & & Diversity & $0.04(.05)$ & -0.06 & 0.15 \\
\hline & & & & & $\begin{array}{c}\text { Non- } \\
\text { diversity }\end{array}$ & $-0.03(.05)$ & -0.13 & 0.06 \\
\hline & $\begin{array}{l}\text { Leader } \\
\text { effectiven } \\
\text { ess }\end{array}$ & & $\begin{array}{c}0.17 \\
(.06)^{* *}\end{array}$ & $0.08(.24)$ & Control & $4.50(.17)$ & 4.16 & 4.84 \\
\hline & & & & & Diversity & $0.07(.10)$ & -0.11 & 0.29 \\
\hline & & & & & $\begin{array}{c}\text { Non- } \\
\text { diversity }\end{array}$ & $-0.06(.09)$ & -0.26 & 0.11 \\
\hline & $\begin{array}{l}\text { Leader } \\
\text { response }\end{array}$ & & $\begin{array}{c}0.14 \\
(.05)^{*}\end{array}$ & $0.01(.23)$ & Control & $4.30(.17)$ & 3.97 & 4.63 \\
\hline & & & & & Diversity & $0.06(.08)$ & -0.09 & 0.24 \\
\hline & & & & & $\begin{array}{c}\text { Non- } \\
\text { diversity }\end{array}$ & $-0.05(.08)$ & -0.22 & 0.09 \\
\hline & Salary & & $\begin{array}{c}0.09 \\
(.03)^{* *}\end{array}$ & $\begin{array}{l}0.004 \\
(.13)\end{array}$ & Control & $1.83(.09)$ & 1.65 & 2.01 \\
\hline & & & & & Diversity & $0.03(.05)$ & -0.07 & 0.14 \\
\hline & & & & & $\begin{array}{c}\text { Non- } \\
\text { diversity }\end{array}$ & $-0.03(.05)$ & -0.14 & 0.05 \\
\hline & Promotio & & $0.12(.06)$ & $-0.20(.26)$ & Control & $3.71(.18)$ & 3.35 & 4.08 \\
\hline & & & & & Diversity & $0.05(.08)$ & -0.08 & 0.22 \\
\hline & & & & & $\begin{array}{c}\text { Non- } \\
\text { diversity }\end{array}$ & $-0.04(.07)$ & -0.20 & 0.07 \\
\hline
\end{tabular}




\begin{tabular}{|c|c|c|c|c|c|c|c|c|}
\hline \multirow[b]{2}{*}{$\begin{array}{c}\text { CEO } \\
\text { identity }\end{array}$} & \multirow[b]{2}{*}{ Outcome } & \multirow[b]{2}{*}{ Est. MX } & \multirow[b]{2}{*}{ Est. YM } & \multirow[b]{2}{*}{$\begin{array}{l}\text { Direct } \\
\text { Effect }\end{array}$} & \multirow[b]{2}{*}{ Error } & \multirow[b]{2}{*}{$\begin{array}{l}\text { Indirect } \\
\text { Effect }\end{array}$} & \multicolumn{2}{|c|}{$\begin{array}{l}\text { Indirect } \\
\text { Effect }\end{array}$} \\
\hline & & & & & & & LCL & UCL \\
\hline \multirow{15}{*}{$\begin{array}{c}\text { Black } \\
\text { women v. } \\
\text { White } \\
\text { women }\end{array}$} & $\begin{array}{l}\text { Leader } \\
\text { attributes }\end{array}$ & $0.38(.36)$ & $\begin{array}{c}0.09 \\
(.03)^{* *}\end{array}$ & $\begin{array}{c}0.004 \\
(.12)\end{array}$ & Control & $3.44(.09)$ & 3.27 & 3.61 \\
\hline & & & & & Diversity & $0.01(.10)$ & -0.18 & 0.21 \\
\hline & & & & & $\begin{array}{c}\text { Non- } \\
\text { diversity }\end{array}$ & $-0.07(.08)$ & -0.26 & 0.08 \\
\hline & $\begin{array}{l}\text { Leader } \\
\text { effectiveness }\end{array}$ & & $\begin{array}{c}0.17 \\
(.06)^{* *}\end{array}$ & $0.10(.24)$ & Control & $4.50(.17)$ & 4.16 & 4.84 \\
\hline & & & & & Diversity & $0.07(.08)$ & -0.07 & 0.25 \\
\hline & & & & & $\begin{array}{c}\text { Non- } \\
\text { diversity }\end{array}$ & $\begin{array}{c}-0.002 \\
(.06)\end{array}$ & -0.13 & 0.11 \\
\hline & $\begin{array}{l}\text { Leader } \\
\text { response }\end{array}$ & & $\begin{array}{c}0.14 \\
(.05)^{*}\end{array}$ & $0.08(.23)$ & Control & $4.30(.17)$ & 3.97 & 4.63 \\
\hline & & & & & Diversity & $0.01(.08)$ & -0.15 & 0.17 \\
\hline & & & & & $\begin{array}{c}\text { Non- } \\
\text { diversity }\end{array}$ & $-0.05(.07)$ & -0.21 & 0.07 \\
\hline & Salary & & $\begin{array}{c}0.09 \\
(.03)^{* *}\end{array}$ & $.013(.13)$ & Control & $1.83(.09)$ & 1.65 & 2.01 \\
\hline & & & & & Diversity & $0.005(.05)$ & -0.11 & 0.09 \\
\hline & & & & & $\begin{array}{l}\text { Non- } \\
\text { diversity }\end{array}$ & $-0.04(.04)$ & -0.14 & 0.04 \\
\hline & Promotion & & $0.12(.06)$ & $0.02(.25)$ & Control & $3.71(.18)$ & 3.35 & 4.08 \\
\hline & & & & & Diversity & $0.01(.07)$ & -0.14 & 0.16 \\
\hline & & & & & $\begin{array}{l}\text { Non- } \\
\text { diversity }\end{array}$ & $-0.04(.06)$ & -0.20 & 0.07 \\
\hline
\end{tabular}


RACE AND GENDER ON CORPORATE ERRORS

\begin{tabular}{|c|c|c|c|c|c|c|c|c|}
\hline \multirow[b]{2}{*}{$\begin{array}{l}\text { CEO } \\
\text { identity }\end{array}$} & \multirow[b]{2}{*}{ Outcome } & \multirow[b]{2}{*}{ Est. MX } & \multirow[b]{2}{*}{$\begin{array}{l}\text { Est. } \\
\text { YM }\end{array}$} & \multirow[b]{2}{*}{$\begin{array}{l}\text { Direct } \\
\text { Effect }\end{array}$} & \multirow[b]{2}{*}{ Error } & \multirow[b]{2}{*}{$\begin{array}{l}\text { Indirect } \\
\text { Effect }\end{array}$} & \multicolumn{2}{|c|}{$\begin{array}{l}\text { Indirect } \\
\text { Effect }\end{array}$} \\
\hline & & & & & & & LCL & $\begin{array}{l}\mathrm{UC} \\
\mathrm{L}\end{array}$ \\
\hline \multirow{15}{*}{$\begin{array}{c}\text { Black } \\
\text { women v. } \\
\text { White } \\
\text { men }\end{array}$} & $\begin{array}{l}\text { Leader } \\
\text { attributes }\end{array}$ & $0.16(.36)$ & $\begin{array}{c}0.09 \\
(.03)^{* *}\end{array}$ & $\begin{array}{l}-0.19 \\
(.03)\end{array}$ & Control & $3.44(.09)$ & 3.27 & 3.61 \\
\hline & & & & & Diversity & $.04(.05)$ & -0.05 & 0.15 \\
\hline & & & & & $\begin{array}{c}\text { Non- } \\
\text { diversity }\end{array}$ & $-.01(.04)$ & -0.10 & 0.06 \\
\hline & $\begin{array}{l}\text { Leader } \\
\text { effectiveness }\end{array}$ & & $\begin{array}{c}0.17 \\
(.06)^{* *}\end{array}$ & $\begin{array}{l}-0.24 \\
(.24)\end{array}$ & Control & $4.50(.17)$ & 4.16 & 4.84 \\
\hline & & & & & Diversity & $.08(.10)$ & -0.10 & 0.30 \\
\hline & & & & & $\begin{array}{c}\text { Non- } \\
\text { diversity }\end{array}$ & $-.03(.08)$ & -0.20 & 0.13 \\
\hline & $\begin{array}{l}\text { Leader } \\
\text { response }\end{array}$ & & $\begin{array}{c}0.14 \\
(.05)^{*}\end{array}$ & $\begin{array}{l}-0.16 \\
(.23)\end{array}$ & Control & $4.30(.17)$ & 3.97 & 4.63 \\
\hline & & & & & Diversity & $0.07(.08)$ & -0.08 & 0.26 \\
\hline & & & & & $\begin{array}{c}\text { Non- } \\
\text { diversity }\end{array}$ & $-.02(.07)$ & -0.17 & 0.11 \\
\hline & Salary & & $\begin{array}{c}0.09 \\
(.03)^{* *}\end{array}$ & $\begin{array}{l}-0.08 \\
(.13)\end{array}$ & Control & $1.83(.09)$ & 1.65 & 2.01 \\
\hline & & & & & Diversity & $0.04(.05)$ & -0.06 & 0.14 \\
\hline & & & & & $\begin{array}{c}\text { Non- } \\
\text { diversity }\end{array}$ & $-0.02(.04)$ & -0.11 & 0.06 \\
\hline & Promotion & & $0.12(.06)$ & $\begin{array}{l}-0.49 \\
(.26)\end{array}$ & Control & $3.71(.18)$ & 3.35 & 4.08 \\
\hline & & & & & Diversity & $0.06(.08)$ & -0.07 & 0.24 \\
\hline & & & & & $\begin{array}{c}\text { Non- } \\
\text { diversity }\end{array}$ & $-0.02(.06)$ & -0.15 & 0.10 \\
\hline
\end{tabular}

Note: Est. MX = bootstrapped estimate of the path from CEO identity to attributions of responsibility. Est. $\mathrm{YM}=$ bootstrapped estimate of path from attributions of responsibility to leader perception outcomes. Indirect Effect $=$ estimates of relative conditional effects of CEO identity on each outcome variable, by corporate error. $\mathrm{LCL}=$ lower confidence limit. $\mathrm{UCL}=$ upper confidence limit. The estimates of Est. MX are the same across outcomes (constant, $b=4.47, S E=.26, p<.001$ ). Standard errors of the bootstrapped estimates appear in parentheses. Indices of moderated mediation were not significant for all analyses. ${ }^{*} p<.05 .{ }^{* *} p<.01$. 
RACE AND GENDER ON CORPORATE ERRORS

Table 12

Bootstrapped (10,000 samples) moderated mediation analyses for the effect of corporate error context on the influence of $C E O$ identity (race $x$ gender) on organization perceptions through attributions of responsibility $(N=396)$

\begin{tabular}{|c|c|c|c|c|c|c|c|c|}
\hline \multirow[b]{2}{*}{$\begin{array}{l}\text { CEO } \\
\text { identity }\end{array}$} & \multirow[b]{2}{*}{ Outcome } & \multirow[b]{2}{*}{ Est. MX } & \multirow[b]{2}{*}{ Est. YM } & \multirow[b]{2}{*}{$\begin{array}{l}\text { Direct } \\
\text { Effect }\end{array}$} & \multirow[b]{2}{*}{ Error } & \multirow[b]{2}{*}{$\begin{array}{l}\text { Indirect } \\
\text { Effect }\end{array}$} & \multicolumn{2}{|c|}{$\begin{array}{l}\text { Indirect } \\
\text { Effect }\end{array}$} \\
\hline & & & & & & & LCL & $\begin{array}{l}\text { UC } \\
\text { L }\end{array}$ \\
\hline \multirow[t]{6}{*}{$\begin{array}{l}\text { Black } \\
\text { men }\end{array}$} & $\begin{array}{l}\text { Behavioral } \\
\text { intentions }\end{array}$ & $0.21(.36)$ & $\begin{array}{c}0.26 \\
(.05)^{* * *}\end{array}$ & $\begin{array}{l}0.07 \\
(.21)\end{array}$ & Control & $0.06(.08)$ & -0.11 & 0.22 \\
\hline & & & & & Diversity & $0.17(.12)$ & -0.05 & 0.41 \\
\hline & & & & & $\begin{array}{c}\text { Non- } \\
\text { diversity }\end{array}$ & $\begin{array}{l}-0.04 \\
(.10)\end{array}$ & -0.23 & 0.16 \\
\hline & $\begin{array}{l}\text { Corporate } \\
\text { reputation }\end{array}$ & & $\begin{array}{c}-0.19 \\
(.05)^{* * *}\end{array}$ & $\begin{array}{l}0.02 \\
(.21)\end{array}$ & Control & $\begin{array}{c}-0.04 \\
(.06)\end{array}$ & -0.18 & 0.08 \\
\hline & & & & & Diversity & $\begin{array}{c}-0.12 \\
(.09)\end{array}$ & -0.33 & 0.03 \\
\hline & & & & & $\begin{array}{c}\text { Non- } \\
\text { diversity }\end{array}$ & $0.03(.07)$ & -0.12 & 0.17 \\
\hline \multirow[t]{6}{*}{$\begin{array}{l}\text { White } \\
\text { women }\end{array}$} & $\begin{array}{c}\text { Behavioral } \\
\text { intentions }\end{array}$ & $0.38(.36)$ & $\begin{array}{c}0.26 \\
(.05)^{* * *}\end{array}$ & $\begin{array}{l}0.19 \\
(.21)\end{array}$ & Control & $0.10(.09)$ & -0.07 & 0.28 \\
\hline & & & & & Diversity & $0.11(.11)$ & -0.10 & 0.35 \\
\hline & & & & & $\begin{array}{c}\text { Non- } \\
\text { diversity }\end{array}$ & $\begin{array}{c}-0.003 \\
(.09)\end{array}$ & -0.18 & 0.16 \\
\hline & $\begin{array}{l}\text { Corporate } \\
\text { reputation }\end{array}$ & & $\begin{array}{c}-0.19 \\
(.05)^{* * *}\end{array}$ & $\begin{array}{l}0.14 \\
(.21)\end{array}$ & Control & $\begin{array}{l}-0.07 \\
(.07)\end{array}$ & -0.22 & 0.04 \\
\hline & & & & & Diversity & $\begin{array}{l}-0.08 \\
(.09)\end{array}$ & -0.27 & 0.08 \\
\hline & & & & & $\begin{array}{c}\text { Non- } \\
\text { diversity }\end{array}$ & $\begin{array}{l}0.002 \\
(.06)\end{array}$ & -0.12 & 0.13 \\
\hline
\end{tabular}


RACE AND GENDER ON CORPORATE ERRORS

Indirect

Effect

\begin{tabular}{|c|c|c|c|c|c|c|c|c|}
\hline $\begin{array}{l}\text { CEO } \\
\text { identity }\end{array}$ & Outcome & Est. MX & Est. YM & $\begin{array}{l}\text { Direct } \\
\text { Effect }\end{array}$ & Error & $\begin{array}{l}\text { Indirect } \\
\text { Effect }\end{array}$ & LCL & UCL \\
\hline \multirow[t]{6}{*}{$\begin{array}{l}\text { White } \\
\text { men }\end{array}$} & $\begin{array}{l}\text { Behavioral } \\
\text { intentions }\end{array}$ & $0.16(.36)$ & $\begin{array}{c}0.26 \\
(.05)^{* * *}\end{array}$ & $\begin{array}{l}0.07 \\
(.21)\end{array}$ & Control & $0.04(.08)$ & -0.12 & 0.21 \\
\hline & & & & & Diversity & $0.17(.12)$ & -0.04 & 0.43 \\
\hline & & & & & $\begin{array}{c}\text { Non- } \\
\text { diversity }\end{array}$ & $\begin{array}{c}-0.001 \\
(.08)\end{array}$ & -0.17 & 0.16 \\
\hline & $\begin{array}{l}\text { Corporate } \\
\text { reputation }\end{array}$ & & $\begin{array}{c}-0.19 \\
(.05)^{* * *}\end{array}$ & $\begin{array}{l}-0.08 \\
(.21)\end{array}$ & Control & $\begin{array}{l}-0.03 \\
(.06)\end{array}$ & -0.17 & 0.09 \\
\hline & & & & & Diversity & $\begin{array}{c}-0.12 \\
(.09)\end{array}$ & -0.31 & -0.04 \\
\hline & & & & & $\begin{array}{c}\text { Non- } \\
\text { diversity }\end{array}$ & $\begin{array}{c}0.001 \\
(.06)\end{array}$ & -0.13 & 0.12 \\
\hline
\end{tabular}

Note: Est. MX = bootstrapped estimate of the path from CEO identity to attributions of responsibility. Est. YM = bootstrapped estimate of path from attributions of responsibility to organization perception outcomes. Indirect Effect $=$ estimates of relative conditional effects of CEO identity on each outcome variable, by corporate error. LCL $=$ lower confidence limit. UCL $=$ upper confidence limit. The estimates of Est. MX are the same across outcomes (constant, $b=4.47, S E=.26, p<.001$ ). Standard errors of the bootstrapped estimates appear in parentheses. Indices of moderated mediation were not significant for all analyses. ${ }^{* * *} p<.001$. 
RACE AND GENDER ON CORPORATE ERRORS

Table 13

Bootstrapped (10,000 samples) moderated mediation analyses for the effect corporate error context on the relative conditional influence of $C E O$ identity (race $x$ gender) on organization perceptions through attributions of responsibility $(N=396)$

\begin{tabular}{|c|c|c|c|c|c|c|c|c|}
\hline \multirow[b]{2}{*}{$\begin{array}{c}\text { CEO } \\
\text { identity } \\
\text { comparis } \\
\text { on }\end{array}$} & \multirow[b]{2}{*}{ Outcome } & \multirow[b]{2}{*}{ Est. MX } & \multirow[b]{2}{*}{ Est. YM } & \multirow[b]{2}{*}{$\begin{array}{l}\text { Direct } \\
\text { Effect }\end{array}$} & \multirow[b]{2}{*}{ Error } & \multirow[b]{2}{*}{$\begin{array}{l}\text { Indirect } \\
\text { Effect }\end{array}$} & \multicolumn{2}{|c|}{$\begin{array}{l}\text { Indirect } \\
\text { Effect }\end{array}$} \\
\hline & & & & & & & LCL & UCL \\
\hline \multirow{6}{*}{$\begin{array}{c}\text { Black } \\
\text { women } v . \\
\text { Black } \\
\text { men }\end{array}$} & $\begin{array}{l}\text { Behavioral } \\
\text { intentions }\end{array}$ & $\begin{array}{l}0.21 \\
(.36)\end{array}$ & $\begin{array}{c}0.26 \\
(.05)^{* * *}\end{array}$ & $\begin{array}{c}2.32 \\
(.25)^{* * *}\end{array}$ & Control & $3.40(.16)$ & 3.10 & 3.71 \\
\hline & & & & & Diversity & $0.11(.14)$ & -0.16 & 0.40 \\
\hline & & & & & $\begin{array}{c}\text { Non- } \\
\text { diversity }\end{array}$ & $-0.09(.13)$ & -0.35 & 0.16 \\
\hline & $\begin{array}{l}\text { Corporate } \\
\text { reputation }\end{array}$ & & $\begin{array}{c}-0.19 \\
(.05)^{* * *}\end{array}$ & $\begin{array}{c}4.91 \\
(.25)^{* * *}\end{array}$ & Control & $4.12(.15)$ & 3.82 & 4.42 \\
\hline & & & & & Diversity & $-0.08(.11)$ & -0.31 & 0.11 \\
\hline & & & & & $\begin{array}{c}\text { Non- } \\
\text { diversity }\end{array}$ & $0.06(.10)$ & -0.12 & 0.27 \\
\hline \multirow{6}{*}{$\begin{array}{c}\text { Black } \\
\text { women v. } \\
\text { White } \\
\text { women }\end{array}$} & $\begin{array}{l}\text { Behavioral } \\
\text { intentions }\end{array}$ & $\begin{array}{l}0.38 \\
(.36)\end{array}$ & $\begin{array}{c}0.26 \\
(.05)^{* * *}\end{array}$ & $0.07(.21)$ & Control & $3.40(.16)$ & 3.10 & 3.71 \\
\hline & & & & & Diversity & 0.01 & -0.26 & 0.30 \\
\hline & & & & & $\begin{array}{c}\text { Non- } \\
\text { diversity }\end{array}$ & $-0.10(.12)$ & -0.36 & 0.13 \\
\hline & $\begin{array}{l}\text { Corporate } \\
\text { reputation }\end{array}$ & & $\begin{array}{c}-0.19 \\
(.05)^{* * *}\end{array}$ & $0.02(.21)$ & Control & $4.12(.15)$ & 3.82 & 4.42 \\
\hline & & & & & Diversity & $-0.01(.10)$ & -0.22 & 0.20 \\
\hline & & & & & $\begin{array}{c}\text { Non- } \\
\text { diversity }\end{array}$ & $0.07(.09)$ & -0.09 & 0.28 \\
\hline
\end{tabular}


RACE AND GENDER ON CORPORATE ERRORS

\begin{tabular}{|c|c|c|c|c|c|c|c|c|}
\hline \multirow[b]{2}{*}{$\begin{array}{l}\text { CEO } \\
\text { identity }\end{array}$} & \multirow[b]{2}{*}{ Outcome } & \multirow[b]{2}{*}{ Est. MX } & \multirow[b]{2}{*}{ Est. YM } & \multirow[b]{2}{*}{$\begin{array}{l}\text { Direct } \\
\text { Effect }\end{array}$} & \multirow[b]{2}{*}{ Error } & \multirow[b]{2}{*}{$\begin{array}{l}\text { Indirect } \\
\text { Effect }\end{array}$} & \multicolumn{2}{|c|}{ Indirect Effect } \\
\hline & & & & & & & LCL & UCL \\
\hline \multirow{6}{*}{$\begin{array}{c}\text { Black } \\
\text { women v. } \\
\text { White } \\
\text { men }\end{array}$} & $\begin{array}{l}\text { Behavioral } \\
\text { intentions }\end{array}$ & $0.16(.36)$ & $\begin{array}{c}0.26 \\
(.05)^{* * *}\end{array}$ & $0.19(.21)$ & Control & $3.40(.16)$ & 3.10 & 3.71 \\
\hline & & & & & Diversity & $0.13(.14)$ & -0.13 & 0.43 \\
\hline & & & & & $\begin{array}{c}\text { Non- } \\
\text { diversity }\end{array}$ & $-0.04(.12)$ & -0.28 & 0.19 \\
\hline & $\begin{array}{l}\text { Corporate } \\
\text { reputation }\end{array}$ & & $\begin{array}{c}-0.19 \\
(.05)^{* * *}\end{array}$ & $0.14(.21)$ & Control & $4.12(.15)$ & 3.82 & 4.42 \\
\hline & & & & & Diversity & $-0.09(.10)$ & -0.31 & 0.10 \\
\hline & & & & & $\begin{array}{c}\text { Non- } \\
\text { diversity }\end{array}$ & $0.03(.09)$ & -0.14 & 0.22 \\
\hline
\end{tabular}

Note: Est. MX = bootstrapped estimate of the path from CEO identity to attributions of responsibility. Est. YM = bootstrapped estimate of path from attributions of responsibility to organization perception outcomes. Indirect Effect = estimates of relative conditional effects of CEO identity on each outcome variable, by corporate error. $\mathrm{LCL}=$ lower confidence limit. UCL $=$ upper confidence limit. The estimates of Est. MX are the same across outcomes (constant, $b=$ $4.47, S E=.26, p<.001)$. Standard errors of the bootstrapped estimates appear in parentheses. Indices of moderated mediation were not significant for all analyses. $* * * p<.001$. 


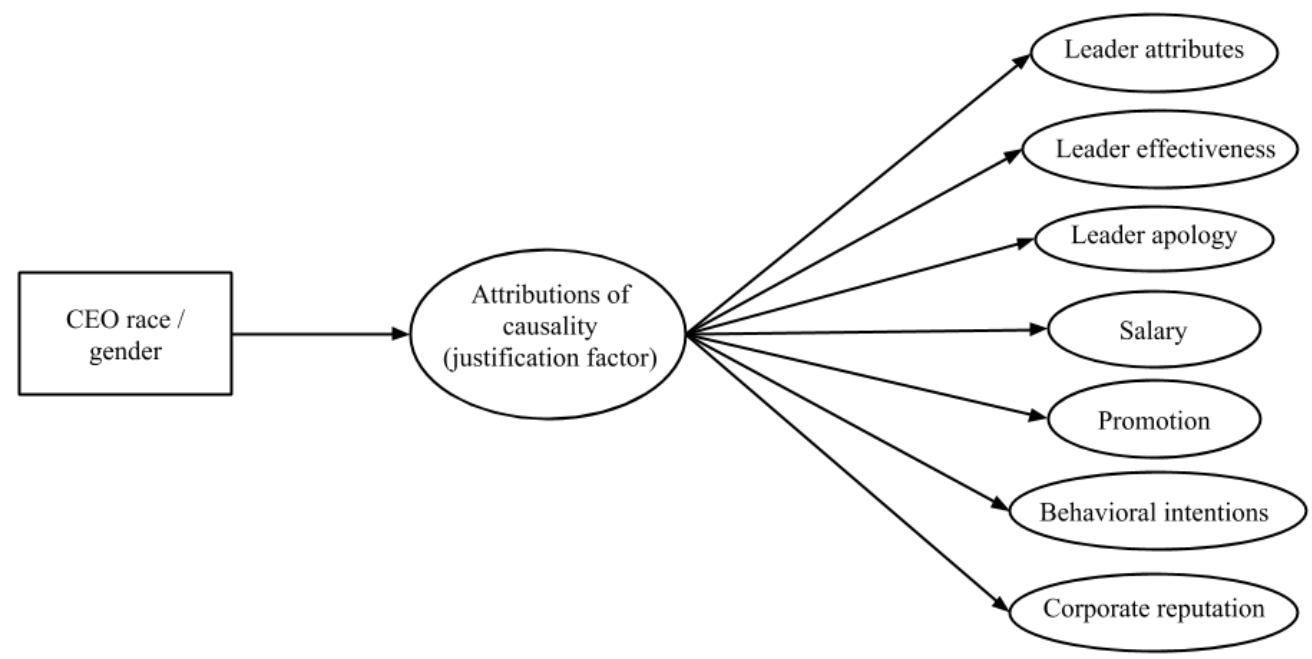

Figure 1. Mediation model (Hypothesis 3) 


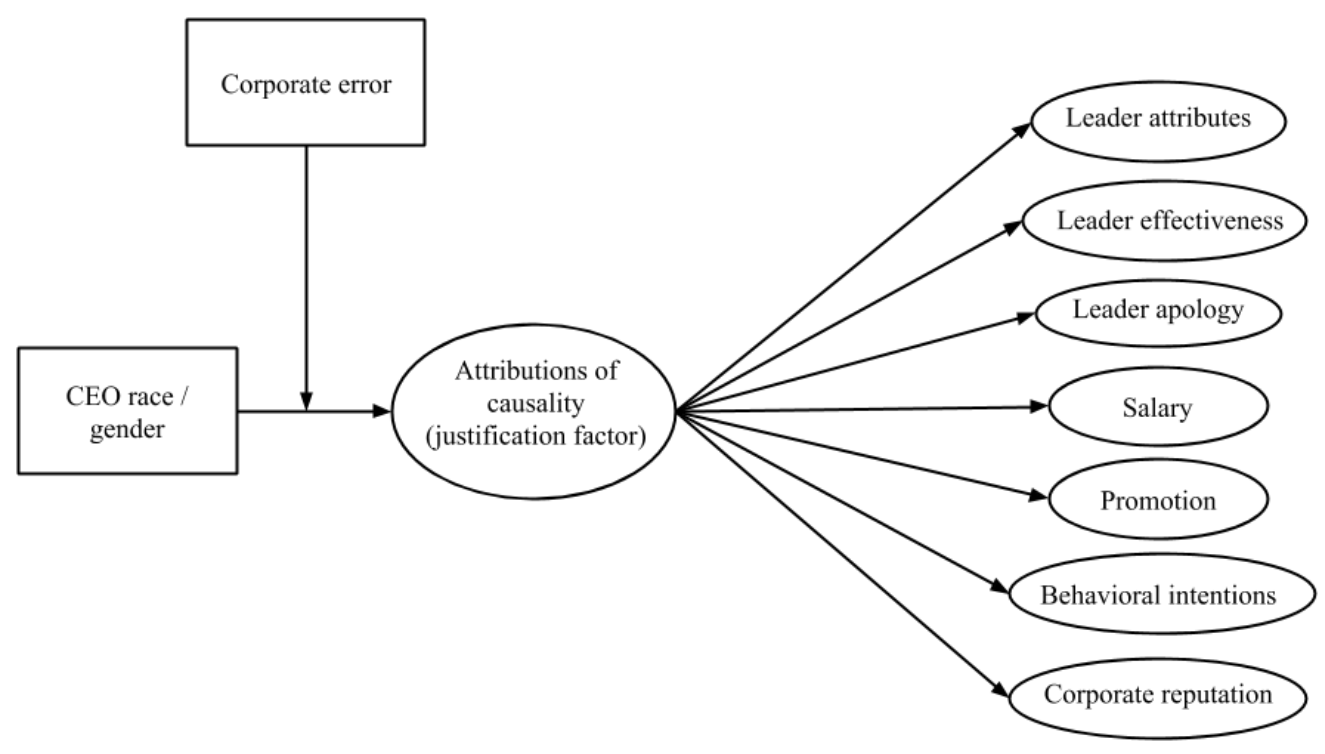

Figure 2. Moderated mediation model (Hypothesis 4) 


\section{References}

Almquist, E. M. (1975). Untangling the effects of race and sex: The disadvantaged status of Black women. Social Science Quarterly, 56, 129-142. Retrieved from http://www.jstor.org/stable/42859476

Apfelbaum, E. P., Norton, M. I., \& Sommers, S. R. (2012). Racial color blindness: Emergence, practice, and implications. Current directions in psychological science, 21, 205-209. https://doi.org/10.1177/0963721411434980

Aronson, J., Jannone, S., McGlone, M., \& Johnson-Campbell, T. (2009). The Obama effect: An experimental test. Journal of Experimental Social Psychology, 45, 957-960. https://doi.org/10.1016/j.jesp.2009.05.006

Ashkanasy, N. M., \& Gallois, C. (1994). Leader attributions and evaluations: Effects of locus of control, supervisory control, and task control. Organizational Behavior and Human Decision Processes, 59, 27-50. https://doi.org/10.1006/obhd.1994.1049

Avery, D. R., McKay, P. F., Volpone, S. D., \& Malka, A. (2015). Are companies beholden to bias? The impact of leader race on consumer purchasing behavior. Organizational Behavior and Human Decision Processes, 127, 85-102. https://doi.org/10.1016/j.obhdp.2015.01.004

Beale, F. (1970). Double jeopardy: To be Black and female. In T. Cade (Ed.), The Black women: An anthology (pp. 90-100). New York, NY: Signet. 
Biernat, M. (1995). The shifting standards model: Implications of stereotype accuracy for social judgment. In Y. T. Lee, L. J. Jussim, \& C. R. McCauley (Eds.), Stereotype accuracy: Toward appreciating group differences (pp. 87-114). Washington, DC: American Psychological Association.

Biernat, M., \& Fuegen, K. (2001). Shifting standards and the evaluation of competence: Complexity in gender-based judgment and decision making. Journal of Social Issues, 57, 707-724. https://doi.org/10.1111/0022-4537.00237

Biernat, M., \& Manis, M. (1994). Shifting standards and stereotype-based judgments. Journal of Personality and Social Psychology, 66, 5-20. doi: $10.1037 / 0022-3514.66 .1 .5$

Biernat, M., Sesko, A. K., \& Amo, R. B. (2009). Compensatory stereotyping in interracial encounters. Group Processes \& Intergroup Relations, 12, 551-563. https://doi.org/10.1177/1368430209337469

Bligh, M. C., Kohles, J. C., Pearce, C. L., Justin, J. E., \& Stovall, J. F. (2007). When the romance is over: Follower perspectives of aversive leadership. Applied Psychology, 56, 528-557. https://doi.org/10.1111/j.1464-0597.2007.00303.x

Bloomberg News (2018, February 15). New details into MetLife pension scandal raise questions and alarms. InvestmentNews. Retrieved from http://www.investmentnews.com/article/20180215/FREE/180219942/new-detailsinto-metlife-pension-scandal-raise-questions-and-alarms 
Bowen, C. C., Swim, J. K., \& Jacobs, R. R. (2000). Evaluating gender biases on actual job performance of real people: A meta-analysis. Journal of Applied Social Psychology, 30, 2194-2215. https://doi.org/10.1111/j.1559-1816.2000.tb02432.x

Bruckmüller, S., \& Branscombe, N. R. (2010). The glass cliff: When and why women are selected as leaders in crisis contexts. British Journal of Social Psychology, 49, 433-451. doi:10.1348/014466609X466594

Brescoll, V. L., Dawson, E., \& Uhlmann, E. L. (2010). Hard won and easily lost: The fragile status of leaders in gender-stereotype-incongruent occupations. Psychological Science, 21, 1640-1642. https://doi.org/10.1177/0956797610384744

Brescoll, V. L., \& Uhlmann, E. L. (2008). Can an angry woman get ahead?: Status conferral, gender, and expression of emotion in the workplace. Psychological Science, 19, 268-275. https://doi.org/10.1111/j.1467-9280.2008.02079.x

Brown, N. D., Martinez, L. R., \& Hebl, M. R. (2018). Prejudice in perceptions of physicians?: The influence of race and gender on evaluations of medical errors. Journal of General Internal Medicine. Advance online publication. https://doi.org/10.1007/s11606-018-4385-y

Carton, A. M., \& Rosette, A. S. (2011). Explaining bias against black leaders: Integrating theory on information processing and goal-based stereotyping. Academy of Management Journal, 54, 1141-1158. https://doi.org/10.5465/amj.2009.0745 
Cook, A., \& Glass, C. (2013). Glass cliffs and organizational saviors: Barriers to minority leadership in work organizations? Social Problems, 60, 168-187. https://doi.org/10.1525/sp.2013.60.2.168

Cook, A., \& Glass, C. (2014). Above the glass ceiling: When are women and racial/ethnic minorities promoted to CEO? Strategic Management Journal, 35, 1080-1089. https://doi.org/10.1002/smj.2161

Coombs, W. T., \& Holladay, S. J. (2002). Helping crisis managers protect reputational assets: Initial tests of the situational crisis communication theory. Management Communication Quarterly, 16, 165-186. https://doi.org/10.1177/089331802237233

Coombs, W. T., \& Holladay, S. J. (2008). Comparing apology to equivalent crisis response strategies: Clarifying apology's role and value in crisis communication. Public Relations Review, 34, 252-257. https://doi.org/10.1016/j.pubrev.2008.04.001

Crandall, C. S. (1994). Prejudice against fat people: Ideology and self-interest. Journal of Personality and Social Psychology, 66, 882-894. http://dx.doi.org/10.1037/00223514.66.5.882

Crandall, C. S., \& Eshleman, A. (2003). A justification-suppression model of the expression and experience of prejudice. Psychological Bulletin, 129, 414-446. https://doi.org/10.1037/0033-2909.129.3.414 
Cronshaw, S. F., \& Lord, R. G. (1987). Effects of categorization, attribution, and encoding processes on leadership perceptions. Journal of Applied Psychology, 72, 97-106. http://dx.doi.org/10.1037/0021-9010.72.1.97

Czopp, A. M., \& Monteith, M. J. (2003). Confronting prejudice (literally): Reactions to confrontations of racial and gender bias. Personality and Social Psychology Bulletin, 29, 532-544. https://doi.org/10.1177/0146167202250923

Devine, P. G. (1989). Stereotypes and prejudice: Their automatic and controlled components. Journal of Personality and Social Psychology, 56, 5-18. http://dx.doi.org/10.1037/0022-3514.56.1.5

Dwivedi, P., Joshi, A., \& Misangyi, V. F. (2018). Gender-inclusive gatekeeping: How (mostly male) predecessors influence the success of female CEOs. Academy of Management Journal, 61, 379-404. https://doi.org/10.5465/amj.2015.1238

Dutton, J. E., \& Dukerich, J. M. (1991). Keeping an eye on the mirror: Image and identity in organizational adaptation. Academy of Management Journal, 34, 517-554. https://doi.org/10.2307/256405

Eagly, A. H. (1987). Sex differences in social behavior: A social-role interpretation. Hillsdale, NJ: Erlbaum.

Eagly, A. H., \& Karau, S. J. (2002). Role congruity theory of prejudice toward female leaders. Psychological Review, 109, 573-598. https://doi.org/10.1037//0033295X.109.3.573 
Eagly, A. H., Karau, S. J., \& Makhijani, M. G. (1995). Gender and the effectiveness of leaders: A meta-analysis. Psychological Bulletin, 117, 125-145. http://dx.doi.org/10.1037/0033-2909.117.1.125

Emrich, C. G. (1999). Context effects in leadership perception. Personality and Social Psychology Bulletin, 25, 991-1006. https://doi.org/10.1177/01461672992511007

Everett, K. (2018, February 13). Bracket appoints Michael Nolte as new CEO. Cision. Retrieved from https://www.prnewswire.com/news-releases/bracket-appointsmichael-nolte-as-new-ceo-300597207.html

Fiske, S. T., Cuddy, A. J. C., Glick, P., \& Xu, J. (2002). A model of (often mixed) stereotype content: Competence and warmth respectively follow from perceived status and competition. Journal of Personality and Social Psychology, 82, 878902. https://doi.org/10.1037/0022-3514.82.6.878

Folkes, V. S. (1988). Recent attribution research in consumer behavior: A review and new directions. Journal of Consumer Research, 14, 548-565. https://doi.org/10.1086/209135

Fortune Editors. (2017). These are the women CEOs leading Fortune 500 companies. Retrieved from http://fortune.com/2017/06/07/fortune-500-women-ceos/ Ghavami, N., \& Peplau, L. A. (2013). An intersectional analysis of gender and ethnic stereotypes: Testing three hypotheses. Psychology of Women Quarterly, 37, 113127. https://doi.org/10.1177/0361684312464203 
Greenhaus, J. H., Parasuraman, S., \& Wormley, W. M. (1990). Effects of race on organizational experiences, job performance evaluations, and career outcomes. Academy of Management Journal, 33, 64-86. https://doi.org/10.2307/256352

Guynn, J. (2017, September 14). Google puts women in lower level, lower paying jobs, new lawsuit says. USA Today. Retrieved from https://www.usatoday.com/story/tech/2017/09/14/google-hit-gender-pay-gaplawsuit-seeking-class-action-status/666944001/

Harvey, P., Madison, K., Martinko, M., Crook, T. R., \& Crook, T. A. (2014). Attribution theory in the organizational sciences: The road traveled and the path ahead. The Academy of Management Perspectives, 28, 128-146.

https://doi.org/10.5465/amp.2012.0175

Haslam, S. A., \& Ryan, M. K. (2008). The road to the glass cliff: Differences in the perceived suitability of men and women for leadership positions in succeeding and failing organizations. The Leadership Quarterly, 19, 530-546. https://doi.org/10.1016/j.leaqua.2008.07.011

Hawkins, L. (2017, November 15). Amid big growth, tech startup Opcity is moving HQ from downtown to Southeast Austin. 512tech. Retrieved from https://www.512tech.com/technology/amid-growth-spurt-tech-startup-opcitymoving-southeast-austin/g4edcuu5DhxkfpTrYtQghJ/

Hayes, A. F. (2015). An index and test of linear moderated mediation. Multivariate Behavioral Research, 50, 1-22. https://doi.org/10.1080/00273171.2014.962683 
Hayes, A. F. (2017). Introduction to mediation, moderation, and conditional process analysis: A regression-based approach (2nd ed.). New York, NY: Guilford Publications.

Hayes, A. F. \& Preacher, K. J. (2014). Statistical mediation analysis with a multicategorical independent variable. British Journal of Mathematical and Statistical Psychology, 67, 451-470. https://doi.org/10.1111/bmsp.12028

Hebl, M. R., \& Mannix, L. M. (2003). The weight of obesity in evaluating others: A mere proximity effect. Personality and Social Psychology Bulletin, 29, 28-38. https://doi.org/10.1177/0146167202238369

Heckman, D. R., Johnson, S. K., Foo, M., Yang, W. (2016). Does diversity-valuing behavior result in diminished performance ratings for non-white and female leaders? Academy of Management Journal, 60, 771-797.

https://doi.org/10.5465/amj.2014.0538

Hegarty, P., \& Golden, A. M. (2008). Attributional beliefs about the controllability of stigmatized traits: Antecedents or justifications of prejudice? Journal of Applied Social Psychology, 38, 1023-1044. https://doi.org/10.1111/j.15591816.2008.00337.x

Heider, F. (1958). The psychology of interpersonal relations. New York, NY: Wiley. Heilman, M. E. (2012). Gender stereotypes and workplace bias. Research in organizational Behavior, 32, 113-135. https://doi.org/10.1016/j.riob.2012.11.003 
Heilman, M. E. (1983). Sex bias in work settings: The lack of fit model. Research in Organizational Behavior, 5, 269-298. Retrieved from http://psycnet.apa.org/record/1984-10927-001

Hello my name is... (2016, December). United States Census Bureau. Retrieved from https://www.census.gov/library/visualizations/2016/comm/cb16tps154_surnames_top15.html

Hernandez, M., Avery, D. R., Tonidandel, S., Hebl, M. R., Smith, A. N., \& McKay, P. F. (2016). The role of proximal social contexts: Assessing stigma-by-association effects on leader appraisals. Journal of Applied Psychology, 101, 68-85. http://dx.doi.org/10.1037/ap10000030

Highhouse, S. (2009). Designing experiments that generalize. Organizational Research Methods, 12, 554-566. https://doi.org/10.1177/1094428107300396

Huang, J. L., Bowling, N. A., Liu, M., \& Li, Y. (2015). Detecting insufficient effort responding with an infrequency scale: Evaluating validity and participant reactions. Journal of Business and Psychology, 30, 299-311. https://doi.org/10.1007/s10869-014-9357-6

Jones, E. E., \& Davis, K. E. (1965). From acts to dispositions the attribution process in person perception. In L. Berkowitz (Ed.), Advances in Experimental Social Psychology (Vol. 2, pp. 219-266). New York, NY: Academic Press. 
Jones, E. E., \& Nisbett, R. E. (1987). The actor and the observer: Divergent perceptions of the causes of behavior. In E. E. Jones, D. E. Kanouse, H. H. Kelley, R. E. Nisbett, S. Valins, \& B. Weiner (Eds.), Attribution: Perceiving the causes of behavior (pp. 79-94). Hillsdale, NJ, US: Lawrence Erlbaum Associates, Inc. Kaiser, C. R., \& Miller, C. T. (2001). Stop complaining! The social costs of making attributions to discrimination. Personality and Social Psychology Bulletin, 27, 254-263. https://doi.org/10.1177/0146167201272010

Kelley, H. H. (1967). Attribution theory in social psychology. In D. Levine (Ed.), Nebraska symposium on motivation (Vol. 15, pp. 192-238). Lincoln, NE: University of Nebraska Press.

Kelley, H. H., \& Michela, J. L. (1980). Attribution theory and research. Annual Review of Psychology, 31, 457-501. http://dx.doi.org/10.1146/annurev.ps.31.020180.002325

Kessler, S. R., Mahoney, K. T., Randolph-Seng, B., Martinko, M. J., \& Spector, P. E. (2017). The effects of attribution style and stakeholder role on blame for the Deepwater Horizon Oil Spill. Business \& Society, 1-27. https://doi.org/10.1177/0007650317717495

King, E. B., Shapiro, J. R., Hebl, M. R., Singletary, S. L., \& Turner, S. (2006). The stigma of obesity in customer service: A mechanism for remediation and bottomline consequences of interpersonal discrimination. Journal of Applied Psychology, 91, 579-593. https://doi.org/10.1037/0021-9010.91.3.579 
Klein, J., \& Dawar, N. (2004). Corporate social responsibility and consumers' attributions and brand evaluations in a product-harm crisis. International Journal of Research in Marketing, 21, 203-217. https://doi.org/10.1016/j.ijresmar.2003.12.003

Knight, J. L., Hebl, M. R., Foster, J. B., \& Mannix, L. M. (2003). Out of role? Out of luck: The influence of race and leadership status on performance appraisals. Journal of Leadership \& Organizational Studies, 9, 85-93. https://doi.org/10.1177/107179190300900308

Knowles, E. D., Lowery, B. S., Hogan, C. M., \& Chow, R. M. (2009). On the malleability of ideology: Motivated construals of color blindness. Journal of Personality and Social Psychology, 96, 857-869.

http://dx.doi.org/10.1037/a0013595

Livingston, R. W., Rosette, A. S., \& Washington, E. F. (2012). Can an agentic Black woman get ahead? The impact of race and interpersonal dominance on perceptions of female leaders. Psychological Science, 23, 354-358. https://doi.org/10.1177/0956797611428079

Lockwood, P. (2006). "Someone like me can be successful": Do college students need same-gender role models? Psychology of Women Quarterly, 30, 36-46. https://doi.org/10.1111/j.1471-6402.2006.00260.x 
Lord, R. G., Foti, R. J., \& De Vader, C. L. (1984). A test of leadership categorization theory: Internal structure, information processing, and leadership perceptions. Organizational Behavior and Human Performance, 34, 343-378. https://doi.org/10.1016/0030-5073(84)90043-6

Lyness, K. S., \& Heilman, M. E. (2006). When fit is fundamental: Performance evaluations and promotions of upper-level female and male managers. Journal of Applied Psychology, 91, 777-785. https://doi.org/10.1037/0021-9010.91.4.777

Malle, B. F. (2011). Attribution theories: How people make sense of behavior. In D. Chadee (Ed.), Theories in social psychology (pp. 72-95). Hoboken, NJ: WileyBlackwell.

Martinko, M. J. (1995). Attribution theory: An organizational perspective. Delray Beach, FL: St. Lucie Press.

Martinko, M. J., Harvey, P., \& Dasborough, M. T. (2011). Attribution theory in the organizational sciences: A case of unrealized potential. Journal of Organizational Behavior, 32, 144-149. https://doi.org/10.1002/job.690

Martinko, M. J., Harvey, P., \& Douglas, S. C. (2007). The role, function, and contribution of attribution theory to leadership: A review. The Leadership Quarterly, 18, 561-585. https://doi.org/10.1016/j.leaqua.2007.09.004

McAuley, E., Duncan, T. E., \& Russell, D. W. (1992). Measuring causal attributions: The revised causal dimension scale (CDSII). Personality and Social Psychology Bulletin, 18, 566-573. https://doi.org/10.1177/0146167292185006 
McCoy, K. (2016, June 29). Bank to pay $\$ 10.6 \mathrm{M}$ over loan discrimination charges. USA Today. Retrieved from https://www.usatoday.com/story/money/2016/06/29/bankpay-106m-over-loan-discrimination-charges/86526572/

McDonald, M. L., Keeves, G. D., Westphal, J. D. (2018). One step forward, one step back: White male top manager organizational identification and helping behavior toward other executives following the appointment of a female or racial minority CEO. Academy of Management Journal, 61, 405-439. https://doi.org/10.5465/amj.2016.0358

McGirt, E. (2017, September 27). The Black ceiling: Why African-American women aren't making it to the top in corporate America. Fortune. Retrieved from http://fortune.com/2017/09/27/black-female-ceos-fortune-500-companies/

McLaughlin, E. C. (2018, April 16). Cafe shut down after protesters enter, chanting 'Starbucks coffee is anti-black!'. CNN. Retrieved from https://www.cnn.com/2018/04/16/us/philadelphia-police-starbucks-arrestprotests/index.html

Meier, B. (2017, April 21). Oscar Muñoz won’t get planned promotion to chairman of United. The New York Times. Retrieved from https://www.nytimes.com/2017/04/21/business/united-airlines-ceo.html Meindl, J. R. (1995). The romance of leadership as a follower-centric theory: A social constructionist approach. The Leadership Quarterly, 6, 329-341. https://doi.org/10.1016/1048-9843(95)90012-8 
Meindl, J. R., \& Ehrlich, S. B. (1987). The romance of leadership and the evaluation of organizational performance. Academy of Management Journal, 30, 91-109. https://doi.org/10.2307/255897

Meindl, J. R., Ehrlich, S. B., \& Dukerich, J. M. (1985). The romance of leadership. Administrative Science Quarterly, 30, 78-102. http://dx.doi.org/10.2307/2392813

Menegus, B. (2018). Thousands of Google employees protest company's involvement in Pentagon Al Drone program. Gizmodo. Retrieved from https://gizmodo.com/thousands-of-google-employees-protest-companysinvolvem-1824988565

Morgenroth, T., Ryan, M. K., \& Peters, K. (2015). The motivational theory of role modeling: How role models influence role aspirants' goals. Review of General Psychology, 19, 465-483. http://dx.doi.org/10.1037/gpr0000059

Most Popular Surnames in the United States. (2016, December). United States Census Bureau. Retrieved from https://www.census.gov/newsroom/pressreleases/2016/cb16-tps154.html

Neuberg, S. L., Smith, D. M., Hoffman, J. C., \& Russell, F. J. (1994). When we observe stigmatized and "normal" individuals interacting: Stigma by association. Personality and Social Psychology Bulletin, 20, 196-209. https://doi.org/10.1177/0146167294202007 
Ng, F. (2017). Asian American Women Leaders' Strategies for Negotiating Intersectional Discrimination Related to Racism and Sexism (Doctoral dissertation). Available from ProQuest Dissertations \& Theses Global (No. 10637226).

Piepenbring, D. (2018, April 13). Chick-fil-A's creepy infiltration of New York City. The New Yorker. Retrieved from https://www.newyorker.com/culture/annals-ofgastronomy/chick-fil-as-creepy-infiltration-of-new-york-city?mbid=social_twitter

Plaut, V. C., Thomas, K. M., \& Goren, M. J. (2009). Is multiculturalism or color blindness better for minorities?. Psychological Science, 20, 444-446. https://doi.org/10.1111/j.1467-9280.2009.02318.x

Powell, G. N., Butterfield, D. A., \& Parent, J. D. (2002). Gender and managerial stereotypes: Have the times changed? Journal of Management, 28, 177-193. https://doi.org/10.1016/S0149-2063(01)00136-2

Purdie-Vaughns, V., \& Eibach, R. P. (2008). Intersectional invisibility: The distinctive advantages and disadvantages of multiple subordinate-group identities. Sex Roles, 59, 377-391. https://doi.org/10.1007/s11199-008-9424-4

Reklaitis, V. (2017). United's stock falls 1.1\%, wipes out \$255 millions off the airline's market cap. Market Watch. Retrieved from https://www.marketwatch.com/story/uniteds-stock-is-set-to-fall-5-and-wipe-1billion-off-the-airlines-market-cap-2017-04-11 
Richardson, A., \& Loubier, C. (2008). Intersectionality and leadership. International Journal of Leadership Studies, 3, 142-161. Retrieved from https://www.regent.edu/acad/global/publications/ijls/new/vol3iss2/IJLS_V3Is2_R ichardson_Loubier.pdf

Richeson, J. A., \& Nussbaum, R. J. (2004). The impact of multiculturalism versus colorblindness on racial bias. Journal of Experimental Social Psychology, 40, 417-423. https://doi.org/10.1016/j.jesp.2003.09.002

Rosette, A. S., Koval, C. Z., Ma, A., \& Livingston, R. (2016). Race matters for women leaders: Intersectional effects on agentic deficiencies and penalties. The Leadership Quarterly, 27, 429-445. https://doi.org/10.1016/j.leaqua.2016.01.008

Rosette, A. S., Leonardelli, G. J., \& Phillips, K. W. (2008). The White standard: Racial bias in leader categorization. Journal of Applied Psychology, 93, 758-777. http://dx.doi.org/10.1037/0021-9010.93.4.758

Rosette, A. S., \& Livingston, R. W. (2012). Failure is not an option for Black women: Effects of organizational performance on leaders with single versus dualsubordinate identities. Journal of Experimental Social Psychology, 48, 11621167. https://doi.org/10.1016/j.jesp.2012.05.002

Ross, L. (1977). The intuitive psychologist and his shortcomings: Distortions in the attribution process. In L. Berkowitz (Ed.), Advances in experimental social psychology (Vol. 10, pp. 173-220). Academic Press. 
Rotundo, M., \& Sackett, P. R. (2002). The relative importance of task, citizenship, and counterproductive performance to global ratings of job performance: A policycapturing approach. Journal of Applied Psychology, 87, 66-80.

https://doi.org/10.1037//0021-9010.87.1.66

Rudman, L. A., \& Glick, P. (2001). Prescriptive gender stereotypes and backlash toward agentic women. Journal of Social Issues, 57, 743-762. https://doi.org/10.1111/0022-4537.00239

Ruggs, E. N., Hebl, M. R., Walker, S. S., \& Fa-Kaji, N. (2014). Selection biases that emerge when age meets gender. Journal of Managerial Psychology, 29, 10281043. https://doi.org/10.1108/JMP-07-2012-0204

Ryu, K., Han, H., \& Kim, T. H. (2008). The relationships among overall quick-casual restaurant image, perceived value, customer satisfaction, and behavioral intentions. International Journal of Hospitality Management, 27, 459-469. https://doi.org/10.1016/j.ijhm.2007.11.001

Sakalli, N. (2002). Application of the attribution-value model of prejudice to homosexuality. The Journal of Social Psychology, 142, 264-271. https://doi.org/10.1080/00224540209603899

Sanchez-Hucles, J. V., \& Davis, D. D. (2010). Women and women of color in leadership: Complexity, identity, and intersectionality. American Psychologist, 65, 171-181. http://dx.doi.org/10.1037/a0017459 
Sawyer, K., Salter, N., \& Thoroughgood, C. (2013). Studying individual identities is good, but examining intersectionality is better. Industrial and Organizational Psychology: Perspectives on Science and Practice, 6, 80-84. https://doi.org/10.1111/iops.12012

Schein, V. E., Mueller, R., Lituchy, T., \& Liu, J. (1996). Think manager-think male: A global phenomenon? Journal of Organizational Behavior, 17, 33-41. Retrieved from http://www.jstor.org/stable/2488533

Shapiro, L. (2012, August 1). Chick-fil-A anti-gay controversy: Gay employees speak out. Huffington Post. Retrieved from https://www.huffingtonpost.com/2012/08/01/chick-fil-a-anti-gay-controversyemployees-speak-out_n_1729968.html

Shen, L. (2017, April 11). United Airlines stock drops \$1.4 billion after passenger removal controversy. Fortune. Retrieved from http://fortune.com/2017/04/11/united-airlines-stock-drop/

Singletary, S. L., \& Hebl, M. R. (2009). Compensatory strategies for reducing interpersonal discrimination: The effectiveness of acknowledgments, increased positivity, and individuating information. Journal of Applied Psychology, 94, 797805. http://doi.org/10.1037/a0014185

Smith, N. A., Martinez, L. R., \& Sabat, I. E. (2016). Weight and gender in service jobs: The importance of warmth in predicting customer satisfaction. Cornell Hospitality Quarterly, 57, 314-328. https://doi.org/10.1177/1938965515622564 
Stout, J. G., Dasgupta, N., Hunsinger, M., \& McManus, M. A. (2011). STEMing the tide: Using ingroup experts to inoculate women's self-concept in science, technology, engineering, and mathematics (STEM). Journal of Personality and Social Psychology, 100, 255-270. http://doi.org/10.1037/a0021385

Swim, J. K., Cohen, L. L., \& Hyers, L. L. (1998). Experiencing everyday prejudice and discrimination. In J. K. Swim \& C. Stangor (Eds.) Prejudice: The target's perspective (pp. 37-60). San Diego, CA: Academic Press.

Swim, J. K., \& Sanna, L. J. (1996). He’s skilled, she’s lucky: A meta-analysis of observers' attributions for women's and men's successes and failures. Personality and Social Psychology Bulletin, 22, 507-519.

https://doi.org/10.1177/0146167296225008

Tajfel, H. \& Turner, J. C. (1986). The social identity theory of intergroup behavior. In S. Worchol \& W. G. Austin (Eds.), Psychology of Intergroup Relations (2nd ed). Chicago: Nelson-Hall.

Vignovic, J. A., \& Thompson, L. F. (2010). Computer-mediated cross-cultural collaboration: Attributing communication errors to the person versus the situation. Journal of Applied Psychology, 95, 265-276. http://dx.doi.org/10.1037/a0018628

Walker, S. S., Madera, J. M., \& Hebl, M. R. (2013). Effects of leader race and leader mistake on patronizing behaviors. The Journal of Business Diversity, 13, 52-64. Retrieved from http://www.nabusinesspress.com/JBD/WalkerSS_Web13_1_2_.pdf 
Weber, R., Camerer, C., Rottenstreich, Y., \& Knez, M. (2001). The illusion of leadership: misattribution of cause in coordination games. Organization Science, 12, $582-$ 598. https://doi.org/10.1287/orsc.12.5.582.10090

Weiner, B. (1985). An attributional theory of achievement motivation and emotion. Psychological Review, 92, 548-573. http://dx.doi.org/10.1037/0033295X.92.4.548

White, G. B. (2017, October 26). There are currently 4 Black CEOs in the Fortune 500. The Atlantic. Retrieved from https://www.theatlantic.com/business/archive/2017/10/black-ceos-fortune$500 / 543960 /$

Wiener-Bronner, D. (2017, October 20). Soon, there will be just 3 black Fortune 500 CEOs. CNN Money. Retrieved from http://money.cnn.com/2017/10/19/news/companies/black-ceos-fortune500/index.html

Willemsen, T. M. (2002). Gender typing of the successful manager-A stereotype reconsidered. Sex Roles, 46, 385-391. https://doi.org/10.1023/A:1020409429645

York, K. M. (1989). Defining sexual harassment in workplaces: A policy-capturing approach. Academy of Management Journal, 32, 830-850. https://doi.org/10.5465/256570 
Yzerbyt, V. Y., Kervyn, N., \& Judd, C. M. (2008). Compensation versus halo: The unique relations between the fundamental dimensions of social judgment. Personality and Social Psychology Bulletin, 34, 1110-1123.

https://doi.org/10.1177/0146167208318602

Zarroli, J. (2016, November 17). JPMorgan Chase paying \$264 million to settle allegations of nepotism in China. NPR. Retrieved from https://www.npr.org/sections/thetwo-way/2016/11/17/502445734/jpmorganchase-paying-264-million-to-settle-allegations-of-nepotism-in-china

Zarya, V. (2018). The share of female CEOs in the Fortune 500 dropped by 25\% in 2018. Fortune. Retrieved from http://fortune.com/2018/05/21/women-fortune-5002018/

Zucker, G. S., \& Weiner, B. (1993). Conservatism and perceptions of poverty: An attributional analysis. Journal of Applied Social Psychology, 23, 925-943. https://doi.org/10.1111/j.1559-1816.1993.tb01014.x 


\section{Appendix A}

\section{Description of the pilot study}

Because I expected leader and organization evaluations to differ primarily on the basis of the CEO's race and gender, I conducted a preliminary study to ensure the manipulated material (Appendix A) would not corrupt my ability to determine whether differences in evaluations were indeed due to the CEO's race and gender. As such, this pilot test had several aims. First, I investigated the assumption that while individuals would rate the control (i.e., no corporate error) scenarios more positively than scenarios involving a corporate error (i.e., diversity and non-diversity), individuals would view diversity related and non-diversity related errors similarly. Second, I conducted this pre-test to verify that the images of the CEOs differed in terms of race and gender but were similar on other dimensions. Third and finally, I pre-tested various names to explore the veracity of holding the first and last name of the CEO constant across all conditions. In accordance to the recommendation of Highhouse (2009), the goal of this pre-test was to extract two exemplars of each error condition (e.g., control, diversity, non-diversity) and of each CEO race and gender (e.g., two images of Black women) to ensure that any differences found were not a factor of idiosyncratic features corresponding with any one error or any one CEO picture found in the Internet search.

\section{Method}

Participants. Participants $(N=195)$ were recruited from Amazon's MTurk to participate in this pilot study in exchange for $\$ 0.50$. Given that the goal of this pre-test 
was to assess the neutrality of error conditions, ratings of CEO images, and CEO names, I did not capture demographic information from participants.

Procedure. Participants were told that they would be helping "prepare materials for a future study" and that they would be viewing several news articles, names, and images of people. Each participant was randomly presented the text of a no error scenario, diversity error scenario, and non-diversity error scenario. The text of the articles were not presented on ostensible websites as they were in the study. Participants were then asked to evaluate a several first names and asked to answer questions assessing the extent to which each name implied a particular race or gender. Finally, participants were randomly presented professional headshots and asked to answer questions about the person in the picture. In total, each participant saw 20 photographs, five of each CEO identity group (e.g., five photos of Black men).

\section{Materials}

\section{Error scenarios}

Appendix D contains the text of each scenario included in this pilot test. For scenarios in which there was no corporate error, I included four different scenarios - two describing the appointment of a new CEO, one describing a company's expansion to a new state, and one describing a company opening a new branch office. For scenarios in which there was a diversity related corporate error, I included five different scenarios. These scenarios included events describing (1) pay discrimination, (2) employee harassment, (3) mortgage loan discrimination, (4) loan discrimination for small business 
entrepreneurs, and (5) hiring discrimination. Each of the diversity error scenarios described discrimination on the basis of both race and gender. Finally, for scenarios in which there was a non-diversity related corporate error, I included three different scenarios. These scenarios included events describing (1) creation of fraudulent credit accounts, (2) failed pension payments to clients, and (3) hiring nepotism.

Participants rated each scenario on four dimensions: severe, bad, positive, and negative. All questions were answered using a 5-point, Likert-type scale $(1=$ not at all to $5=$ extremely). To ensure participants attended to the article, they were asked to answer, "What happened in this article?" Participants that did not answer this question correctly were not included in the analyses. Furthermore, to ensure that participants perceived diversity errors as diversity-related errors and did not consider non-diversity errors as diversity-related errors, participants were also asked to select the type of error they believe the company had. Seven error types were included (e.g., diversity, ethical, environmental, leadership, technological, financial, and personnel error). Given that each scenario was adapted from real events that have been covered in popular business news media outlets, participants were also asked whether (or not) they recognized the article or the company associated with the event. The number of participants who answered "yes" and correctly named the company was taken into account in choosing scenarios for use in the subsequent study. 


\section{CEO names}

Participants were asked to evaluated four different first names to assess understand the extent to which first names would be perceived adequate across CEO race and gender conditions. The four names included in the pilot study were: Jordan, Alex, Pat, and Sam. These names were chosen based on the Popular Baby Names database managed by the U.S. Social Security Administration ("Top 10 Baby Names of 2017," 2017). While the surname, Williams, was not pre-tested against other surnames, this surname was chosen based on 2010 U.S. Census data ("Hello my name is...," 2016; "Most Popular Surnames in the United States," 2016).

Participants rated each name based on perceptions of masculinity and femininity, perceived racial group affiliation, or perceived gender. Two unipolar scales and one bipolar were used to capture perceptions of masculinity and femininity (e.g., "Please rate the extent to which you think ALEX is a masculine/feminine name.”). Participants responded to each question using a sliding scale from 0 to 50, anchored by 0 (not very masculine/feminine) to 50 (very masculine/feminine). Participants also responded to a bipolar masculine-feminine scale comparing the extent to which the person in the above image was masculine or feminine (e.g., "Please indicate how masculine or feminine you think the name ALEX is.”). This was a sliding scale from 0 to 100 , anchored by 0 (masculine) and 100 (feminine). Furthermore, participants were asked to answer, "Do you think the name [NAME] is more masculine, feminine, or neutral?," for each name. 
Finally, participants were asked to select the racial/ethnic groups they believed each name to be associated with; participants were told to select all that apply for this question.

\section{CEO photographs}

Professional-looking headshots were obtained from a Google Image search. Various headshots were selected for each race and gender group in order to pre-test images of people that while may not look similar, can easily be recognized by their racial and gender group membership. In other words, this image search was not restricted to headshot of people that looked similar regarding age, hair color, or attractiveness. As such, I collected a total of 45 images of individuals from this Internet search. In total, 9 images of Black women, 9 images of Black men, 13 images of White women, and 14 images of White men were pre-tested. Participants were instructed to evaluate each target in the photograph based on professionalism, intelligence, attractiveness, and friendliness. Furthermore, participants were asked to designate the race and gender of each person in the image. Finally, participants were asked if they recognized the person in each image.

\section{Results}

\section{Error scenarios}

As expected, there were significant differences between no error scenarios and corporate error scenarios, regardless of the type of corporate error, in terms of the degree to which participants thought the events were severe, bad, positive, and negative (all $p>$ .05). Examining differences among no error scenarios specifically, I found no significant differences across scenarios in which no corporate error was involved in terms of 
perceptions that the event was severe, bad, positive, and negative (all $p>.05$ ). As such, I chose one scenario describing the appointment of a new CEO and one describing the opening of a new office branch.

Furthermore, no significant differences were found comparing diversity related errors to non-diversity related errors in terms of the degree to which participants believed the events were positive, negative, bad, and severe (all $p>.05$ ). For diversity related corporate errors, I selected one error describing employee pay discrimination and one error describing allegations of harassment. Although there were no significant differences between non-diversity related errors, I discarded one error (i.e., error describing the creation of fraudulent credit accounts, based on Wells Fargo) on the basis that participants recognized this error and correctly named the company associated with that error. Out of the respondents who recognized the error $(n=19), 74 \%$ correctly listed Wells Fargo as the company associated with the error. Thus, I selected the other two nondiversity related errors that were included in the pre-test, which described failed pension payments and hiring nepotism.

\section{CEO name}

There were no significant differences among the names included in the pre-test, thus I chose the name Jordan Williams based on face validity.

\section{CEO photographs}

Results from this pilot test were first targeted at examining potential differences within each race and gender condition (i.e., comparing Black women to other Black 
women). First, I examined whether various exemplars within each CEO identity group (i.e., Black women, Black men, White women, White men) were significantly different from one another. I only retained those images that were not significantly different from other exemplars within each CEO identity condition. Within images of Black women, one image was significantly different from the others in terms of perceived friendliness (all $p<.001$ ), and therefore I discarded this image from further use. Likewise, within images of White women, one image was significantly different from three other images in terms of perceived friendliness (all $p<.05$ ). There were no significant differences within images of White men and Black men.

Second, I compared images across CEO identity condition to ensure that features other that the target's race or gender would not corrupt the findings in the subsequent study. As expected, there were no significant differences in terms of professionalism, intelligence, attractiveness, and friendliness when Black women, Black men, White women, and White men were compared (all $p>.05$ ). Given the lack of significant differences, I chose two images of Black women, Black men, White women, and White men based on face validity for use in the study. 


\author{
Appendix B
}

Example of website manipulation

GN

Money Companies Markets Tech Medr

\title{
Cook \& Price Financial CEO apologizes amid claims of discrimination
}

\section{by Jason Hughes}

(C) May 12, 2017: 6:23 AM ET
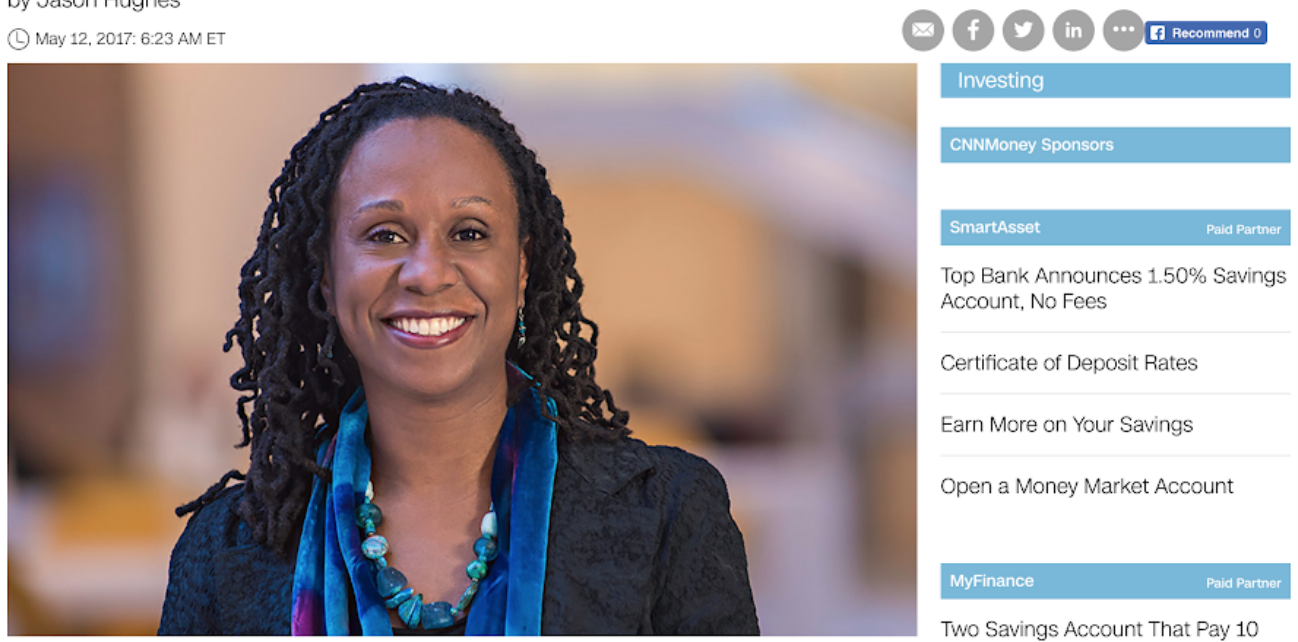

Top Bank Announces 1.50\% Savings Account, No Fees

Certificate of Deposit Rates

Earn More on Your Savings

Open a Money Market Account

\section{MyFinance}

Two Savings Account That Pay 10 Times What Your Bank Pays

Cook \& Price Financial CEO, Jordan Williams (pictured above), released a statement expressing "confusion" and "disappointment," over raised concerns of racial and gender pay discrimination.

A Jaw-Dropping Card With a $0 \%$ Apr Until May 2019

Cook \& Price Financial is in the midst of a media firestorm after an announcement that the company is being sued for racial and gender pay discrimination. On Tuesday, three former Cook \& Price employees filed a class-action suit with San Francisco Superior Court.

How to $10 x$ Your Savings With These New Accounts

The lawsuit is being brought by three employees - Kelly Garcia-Burke, Brenda Ford, and Martin Johnson - who say they quit Cook \& Price after being placed at lower job levels, resulting in Pay No Balance Transfer Fees With This O\% APR Card

The plaintiffs allege ethnic minorities and women across Cook \& Price are paid less than White employees and men, and receive less opportunity for upward mobility.

Jordan Williams, the CEO of Cook \& Price, has not been accused of any wrongdoing; the discrimination cases date back several years and she only became CEO in January 2015.

In her first public statement after the suit was made public, Williams said that Cook \& Price "take[s] these allegations very seriously," and that employee discrimination is "against everything we believe in."

Related: Samsung chief walks free after prison sentence suspended

For some experts in the Bay area, those admissions were a sharp contrast to the confrontational win-at-all-costs attitude often associated with Cook \& Price. Cook \& Price, which pledged to close the race and gender gap to make its workforce better reflect the panoply of people it serves around the country, is still overwhelmingly male and employs very few African Americans and Hispanics. 
Appendix C

Photographs of CEOs

Black women:
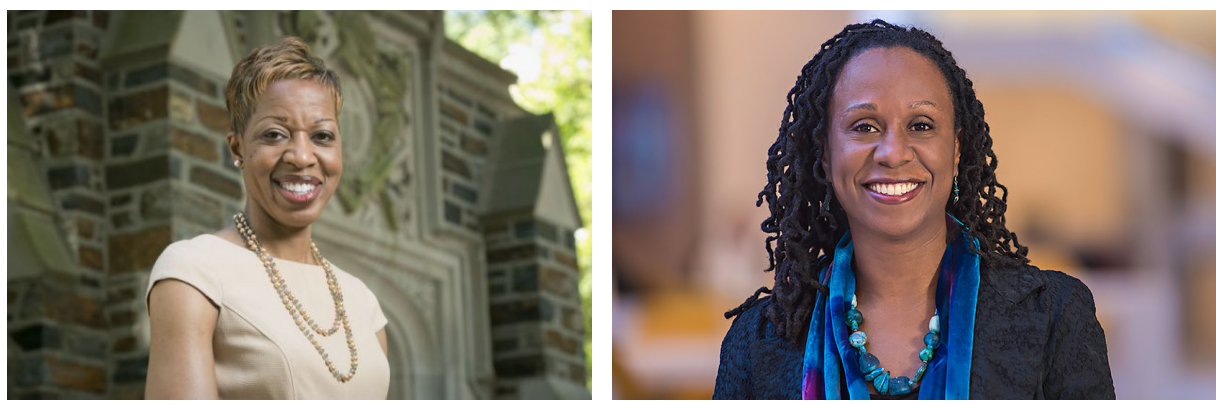

Black men:
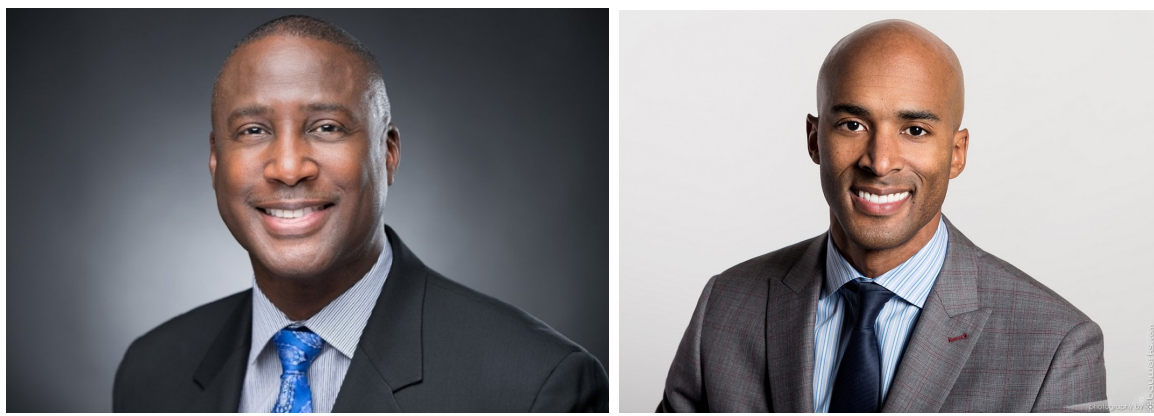

White women:
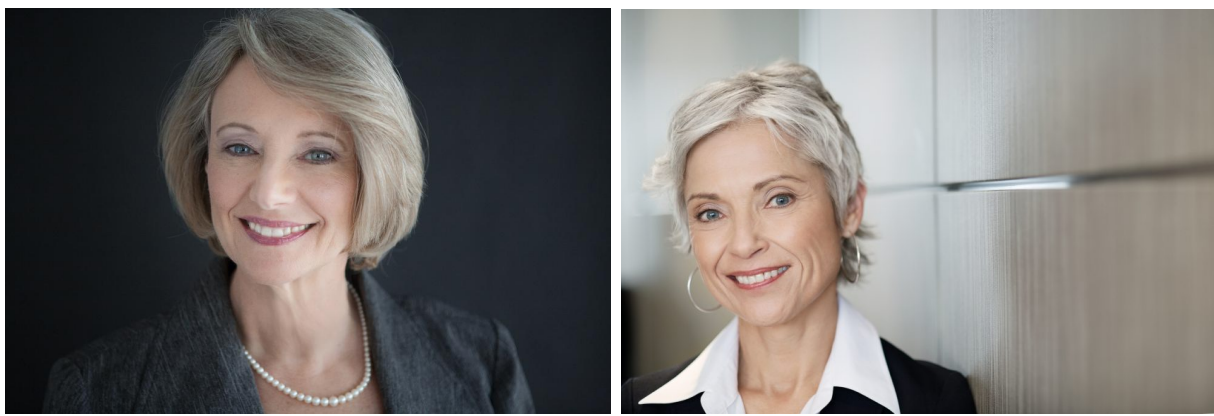

White men:
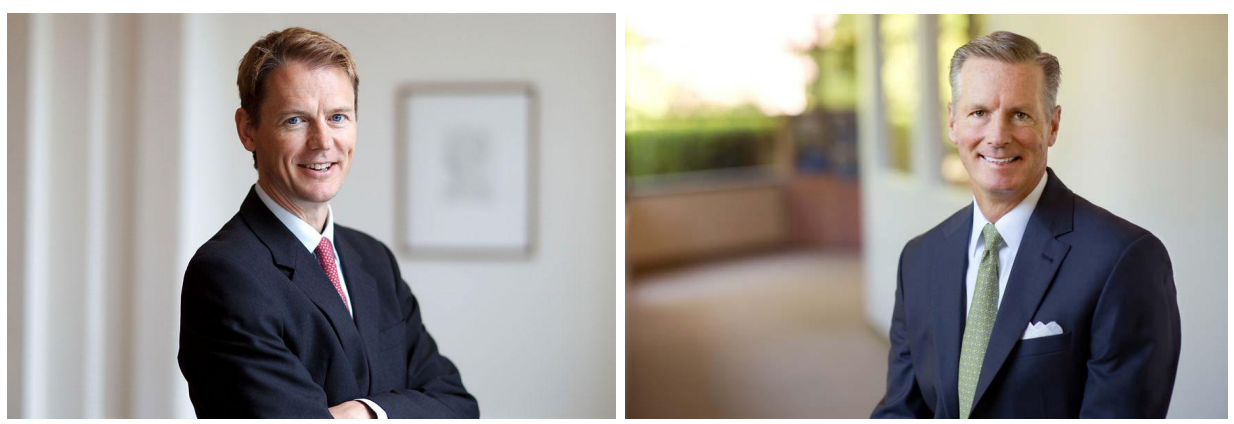


\author{
Appendix D \\ Corporate event scenarios ${ }^{3}$ \\ **Control \#1: Appointment of new CEO
}

Title: Cook \& Price appoints Jordan Williams as new CEO

Sub-title: Cook \& Price Financial announced that Jordan Williams will be the financial company's new CEO.

Cook \& Price Financial, the wealth management conglomerate, is preparing for a fresh start as it welcomes Jordan Williams as its new CEO.

Williams has spent nearly half of his/her life working in investment management, including working at Bank of America, GE, and McKinsey \& Company, among other firms.

$\mathrm{He} / \mathrm{She}$ tells us that working for Cook \& Price, currently at 500,000 employees, marks the first time in which his/her values truly match those of the company's mission, its foundation and its impact on the world.

Williams says that Cook \& Price "will always do what's right for our customers," which is a prime reason he/she joined the company. "I'm so proud, and I feel grateful and humbled to be in this position," Williams says. "Cook \& Price has done so well and accomplished so much in such a short period. I believe that we are well suited to help our clients to succeed financially."

Williams says he/she wants "embody the corporate vision for all to see and fully embrace Cook \& Price's goals and mission into daily decisions."

Reminiscing about his/her time at The University of Chicago Booth School of Business, which he/she graduated from in 2002, Williams says putting people first has been the most valuable business lesson he/she learned and still follows in his/her leadership roles today.

"It's all about treating people well," Williams says. "I believe in caring deeply about the people that will enable a company that I'm running to get there."

"It's not about me," he/she adds. "It's about the team."

\footnotetext{
$3 * *$ denotes that the scenario was utilized in the final study
} 
For his/her first few weeks, he/she plans to spend a lot of time listening to, and learning from his/her employees and clients.

"My goal is to focus the company on how we can accomplish the vision of Cook \& Price," he/she says. "I think it's a wonderful one." 


\section{Control \#2: Appointment of new CEO}

Title: Cook \& Price appoints Jordan Williams as new CEO

Sub-title: Cook \& Price Financial announced that Jordan Williams will be the financial company's new CEO.

Cook \& Price Financial, a leading financial services provider, today announced the appointment of Jordan Williams as Chief Executive Officer. The company's previous CEO, Martin Singer, will transition to the Cook \& Price Board of Directors as a strategic advisor.

Jordan Williams is a seasoned industry leader who joins Cook \& Price after serving as the Chief Financial Officer of Empirical Wealth Management in Seattle, WA. With a career spent in finance, Williams's depth of experience, strategic insight, and proven track record align well with Cook \& Price's goals as it continues to invest in becoming a leading nationwide financial services corporation.

"I am thrilled to join Cook \& Price, and I look forward to this unique opportunity in an outstanding business at a unique and pivotal moment," says Williams.

Before Empirical, Jordan spent seven years at GE, where he/she served as a senior executive manager on GE's global leadership and strategy team. Jordan's early career included five years with McKinsey \& Company and three years at Bank of America. $\mathrm{He} / \mathrm{She}$ holds a Master of Business Administration degree from The University of Chicago Booth School of Business.

"Jordan is the ideal leader for Cook \& Price as we scale the business and broaden the company's impact on clinical research," said David Golde, Director at Greystar Capital. "With Jordan's deep background in healthcare, his/her successful track record as a technology executive and his/her pragmatic leadership style, I'm confident in his/her ability to accelerate Cook \& Price's growth initiatives, both organically and through acquisitions, as Cook \& Price continues to increase the value proposition it provides to its customers." 


\section{**Control \#3: Branch expansion to new state}

Title: Cook \& Price Opens New Office in Austin Amid Tremendous Growth in US Sub-title: Cook \& Price Financial recently announced that they will be expanding to Austin, TX.

Cook \& Price Financial, a leading wealth management company, announced today that it is expanding its national footprint with the opening of its new office in Austin, TX.

Cook \& Price is the latest national financial firm to expand to Austin, as Texas continues to develop top financial talent, attracting investment, and furthering its reputation as a leader in finance throughout the United States. With a significant number of offices across the country - including New York, Chicago, San Diego, and Atlanta - the Austin office will serve as a strategic hub for the company in the US.

"We have seen tremendous growth in the US, and I am extremely excited about expanding Cook \& Price to Texas," said Jordan Williams, founder, and CEO of Cook \& Price. "Despite our already strong client base in the South, Austin was essentially calling us to establish a more permanent presence to continue attracting some of the best talent in wealth management, and to put ourselves in a better position to offer the top-notch client services that our customers have come to expect."

The new US office joins the company's other locations in New York, San Francisco, Los Angeles, Chicago, Atlanta, Detroit, and Boston, giving Cook \& Price eight offices across the US. The expansion comes during a time of extreme growth for the company, which tracked more than $\$ 14$ billion in revenue during 2015, has grown from 80 to 600 employees since 2013, and measures 200 billion mobile events every month.

"There is an incredible opportunity to help steward the growth of Austin as a financial hub in the US, and I look forward to helping expand the company's presence in the region," CEO Jordan Williams says.

Cook \& Price is currently hiring in its Austin office for positions in sales, marketing, partner development, customer success, support and more. The company offers an entrepreneurial culture, stock options, competitive salary, professional development opportunities and excellent benefits. 


\section{Control \#4: Branch expansion}

Title: Top financial company opens new branch

Sub-title: Cook \& Price Financial recently announced that they will be expanding to Calabasas.

Cook \& Price Financial Group, one of the top 75 wealth management companies in America, has announced the opening of a new Los Angeles-area branch in Calabasas, Calif.

The location previously housed a branch of a local mortgage lender, and Cook \& Price is retaining the branch manager, top-producing loan originators, and some support staff.

"This new branch is a big leap for us in the Los Angeles area," said Jordan Williams, Cook \& Price CEO. "Bringing an entirely new office on board with a veteran group of leadership, origination and support talent is ideal, and that's what we've done here."

In its inaugural year, Cook \& Price's Calabasas branch will be managed by Williams, a 28 -year veteran of the financial industry. His/Her experience includes 17 years as owner and president of his/her own mortgage company, leadership positions with several lenders in the region and an established name as a speaker, author, consultant, and motivator.

"One of my first actions with Cook \& Price was to send out a recruiting letter to outside financial officers, and I've never had an easier time promoting a company," Williams said. "All I had to do was list the great service, aggressive rates, accessible leadership and other amazing resources we offer at Cook \& Price."

Cook \& Price, an Illinois-based national mortgage lender, established its first presence in California with the May 2017 opening of its Sherman Oaks branch in Los Angeles. The company plans to expand throughout the West Coast and Southwest and has new or upcoming branch locations in Irvine, Calif.; Las Vegas; Scottsdale, Ariz.; and Portland, Ore. 


\section{**Diversity \#1: Pay discrimination}

Title: Cook \& Price Financial CEO apologizes amid employee claims of discrimination Sub-title: Cook \& Price Financial CEO Jordan Williams released a statement expressing "confusion" and "disappointment," over raised concerns of racial and gender pay discrimination.

Cook \& Price Financial is in the midst of a media firestorm after an announcement that the company is being sued for racial and gender pay discrimination. On Tuesday, three former Cook \& Price employees filed a class-action suit with San Francisco Superior Court.

The lawsuit is being brought by three employees - Kelly Garcia-Burke, Brenda Ford, and Martin Johnson - who say they quit Cook \& Price after being placed at lower job levels, resulting in lower pay and denying them promotions.

The plaintiffs allege ethnic minorities and women across Cook \& Price are paid less than White employees and men and receive less opportunity for upward mobility.

Jordan Williams, the CEO of Cook \& Price, has not been accused of any wrongdoing; the discrimination cases date back several years, and he/she only became CEO in January 2015.

In his/her first public statement after the suit was made public, Williams said that Cook \& Price "take[s] these allegations very seriously," and that employee discrimination is "against everything we believe in."

For some experts in the Bay area, those admissions were a sharp contrast to the confrontational, win-at-all-costs attitude often associated with Cook \& Price. Cook \& Price, which pledged to close the race and gender gap to make its workforce better reflect the panoply of people it serves around the country, is still overwhelmingly male and employs very few African Americans and Hispanics.

"They've been very proactive here, aggressive, and just trying to mitigate and handle a problem without making excuses or being combative," said John Arpin, a partner with San Francisco-based NVM Ventures. "That can either be a sign of company maturity, individual maturity, or perhaps, a proximity to a public path."

Attorney James Carhartt of Perkins Davis is representing the former employees and has asked any Cook \& Price employees to come forward if they had experienced pay discrimination. He and his team heard from 90 current and former employees. 
"That's a strong outpouring of dissatisfaction," Carhartt said. "The stories of these employees were consistent with what my plaintiffs experienced, that minorities are paid less in every category." 


\section{**Diversity \#2: Employee harassment}

Title: Cook \& Price Financial CEO apologizes amid employee claims of harassment Sub-title: Cook \& Price Financial CEO Jordan Williams released a statement expressing "confusion" and "disappointment," over raised concerns of racial and gender workplace harassment.

Cook \& Price was rocked by scandal this week after former employees raised claims of both sexual and racial harassment. Experts say the CEO's conciliatory response may signal Cook \& Price is growing up.

Tuesday morning Cook \& Price CEO Jordan Williams gathered his/her employees in an all-hands meeting to discuss the explosive allegations, said a Cook \& Price employee who attended the meeting and declined to be named. Williams admitted to making mistakes, the employee said. Cook \& Price had failed to prioritize diversity and inclusion, Williams told his/her team and didn't adequately ramp up its human resources department to keep up with the company's explosive growth.

Williams, himself/herself, has not been accused of any wrongdoing; the harassment cases date back several years, and he/she only became CEO in January 2015.

In his/her statement Williams said that Cook \& Price "take[s] these allegations very seriously," and that employee discrimination is "against everything we believe in."

For some experts in New York City, those admissions were a sharp contrast to the confrontational, win-at-all-costs attitude often associated with Cook \& Price. The allegations lodged against Cook \& Price shows that the company continues to struggle to include and value women and minority employees.

“They've been very proactive here, aggressive, and just trying to mitigate and handle a problem without making excuses or being combative," said Chris Fuller, a partner with Brooklyn-based NVM Ventures. "That can either be a sign of company maturity, individual maturity, or perhaps, a proximity to a public path."

Last Sunday, several accounts from former Cook \& Price engineers were published claiming the company's human resources team a protected a male manager who propositioned her for sex and engaged in inappropriate behavior with other women. Instead of punishing the manager, an employee says, Cook \& Price forced her to transfer to another team and later gave her a negative performance review. 
This account comes not long after a firestorm of complaints in 2014 from several minority employees speaking out of being denied promotions and paid less than their coworkers.

And at 10 a.m. on Tuesday, in the large "all-hands" room in Cook \& Price's New York headquarters, Williams spent more than an hour fielding questions from concerned employees, the person who attended the meeting said.

In the "all-hands" meeting, Williams spent more than an hour fielding questions from concerned employees, the person who attended the meeting said. Also at the meeting, Williams reported that women and minorities fill 30 percent of the company's engineering, product management, and scientist roles. Until now, Cook \& Price had not made their demographic statistics public. 


\section{Diversity \#3: Loan discrimination}

Title: Cook \& Price Financial CEO apologizes for loan discrimination charges

Sub-title: Cook \& Price Financial CEO Jordan Williams released a statement expressing "confusion" and "disappointment," over recent charges of loan discrimination towards racial minorities and women.

Cook \& Price has agreed to pay a \$10.6 million settlement of allegations the Californiabased regional financial company used discriminatory mortgage lending practices that harmed African Americans and women, federal officials said Wednesday.

A federal court complaint filed by the Department of Justice and Consumer Financial Protection Bureau alleged bank officials told loan officers to "turn down" minority mortgage applicants more quickly than whites, and avoid giving "borderline" applicants credit assistance that other mortgage seekers might receive.

A spokesperson from Cook \& Price disagreed with the allegations and did not admit liability, but agreed to the filing of the proposed consent order.

Jordan Williams, the CEO of Cook \& Price, has not been accused of any wrongdoing; the discrimination cases date back several years, and he/she only became CEO in January 2015.

In his/her first public statement after the suit was made public, Williams said that Cook \& Price "take[s] these allegations very seriously," and that employee discrimination is "against everything we believe in."

The court complaint charged that an audio recording of an internal Cook \& Price meeting around September 2012 "clearly articulates the firm's policy or practice to reject minority applicants more quickly than white applicants, as well as the firm's perception of African Americans."

During the session, a Cook \& Price manager instructed loan officers and processors that mortgage applications from minorities, others the bank viewed as "protected class" members, and women, particularly single women, should be "turned down" in 21 days, the complaint said.

"When banks discriminate on the basis of race and gender, they violate our civil rights laws and threaten the foundation of a fair economy," said Rachel Lopez, the head of the Department of Justice's Civil Rights Division.

The CFPB found support for the allegations by sending testers to several Cook \& Price 
branches to ask about mortgages. CFPB Director Rick Philbrick said the findings showed that the firm's mortgage lending process "harmed the people who were overcharged or denied their dream of ownership based on their race or sex."

If the consent order wins approval, the bank will pay $\$ 4$ million in direct loan subsidies to various areas in Los Angeles, at least $\$ 800,000$ to fund community programs, outreach and credit repair, $\$ 2.78$ million to people unlawfully denied or overcharged for loans, and a $\$ 3$ million penalty. 


\section{Diversity \#4: Lending discrimination}

Title: Cook \& Price Financial CEO apologizes following allegations of lending discrimination

Sub-title: Cook \& Price Financial CEO Jordan Williams released a statement expressing "confusion" and "disappointment," over recent charges of lending discrimination towards racial minorities and women.

Cook \& Price Financial agreed to a $\$ 55$ million settlement with the government over allegations that it discriminated against "thousands" of African American and women entrepreneurs, it was disclosed Wednesday.

The firm's independent brokers denied women and minority entrepreneurs small-business loans during from 2006 to 2009, compared to "similarly situated white borrowers," according to a government lawsuit filed in a New York federal court.

Cook \& Price is expected to settle the lawsuit for $\$ 55$ million without admitting any liability.

Jordan Williams, the CEO of Cook \& Price, has not been accused of any wrongdoing; the discrimination cases date back six years, and he/she only became CEO in January 2015.

In his/her first public statement after the suit was made public, Williams said that Cook \& Price "take[s] these allegations very seriously," and that employee discrimination is "against everything we believe in."

The business loan lawsuit, filed by U.S. attorney Peter Brooks of the Southern District of New York, alleges that female or Black loan applicants were denied nearly three times as much as white business loan applicant with a similar educational background and the same risk profile.

Altogether, the alleged discrimination "limits that opportunities for minorities and women to have the necessary resources to build their businesses," the government said.

Cook \& Price Financial attorneys denied the allegations in a response filed in court.

In the lawsuit, the U.S. government sought damages for borrowers, civil penalties and an order preventing further discrimination.

The bank gave its independent mortgage brokers the discretion to adjust pricing based on factors not related to borrower risk without documentation or justification, the government alleged. The lawsuit also accuses Cook \& Price of rewarding brokers with 
bonuses for charging interest rates above those based on standard credit criteria.

"Even when Cook \& Price had reason to know there were disparities, however, Cook \& Price did not act to determine the full scope of these wholesale pricing disparities, nor did it take prompt and effective action to eliminate those disparities, nor did it engage in adequate efforts to remedy the impact of those disparities upon the borrowers," the plaintiffs charged in the lawsuit. 


\section{Diversity \#5: Hiring discrimination}

Title: Cook \& Price Financial CEO apologizes in response to charges of hiring discrimination

Sub-title: Cook \& Price Financial CEO Jordan Williams released a statement expressing "confusion" and "disappointment," over recent charges of lending discrimination towards racial minorities and women.

Cook \& Price Financial Group, a leading wealth management firm, has agreed to pay $\$ 10.5$ million and provide other significant relief to settle a hiring discrimination and retaliation lawsuit brought by the U.S. Equal Employment Opportunity Commission (EEOC), the agency announced today.

The nationwide agreement seeks to strengthen and improve Cook \& Price's hiring and recruiting practices of women and non-White employees and resolves a pattern-orpractice lawsuit filed by the EEOC on Sept. 21, 2011. The EEOC's suit charged that the company discriminated in hiring at its retail stores, unlawfully retaliated against employees who opposed practices they believed to be unlawful and failed to adhere to federal record-keeping laws and regulations.

Jordan Williams, the CEO of Cook \& Price, has not been accused of any wrongdoing; the discrimination cases date back several years, and he/she only became CEO in January 2015.

In his/her first public statement after the suit was made public, Williams said that Cook \& Price "take[s] these allegations very seriously," and that employee discrimination is "against everything we believe in."

A central focus of the agreement is strengthening Cook \& Price's diversity efforts and its commitment to non-discriminatory hiring, including the appointment of a director of diversity and inclusion, affirmative outreach efforts to increase diversity in its workforce, updated EEO policies and hiring practices, and annual EEO training for management and non-management employees.

"The EEOC is pleased to have reached what the agency believes to be a fair resolution," said EEOC Deputy General Counsel Jennifer Grimes. "We look forward to working with Cook \& Price in implementing the consent decree." 
EEOC Houston District Office Regional Attorney Rudy Smart said, "The EEOC commends Cook \& Price for its efforts in bringing the pending litigation to a conclusion, and for its commitment to hiring a diverse workforce." 


\section{Non-diversity \#1: Fake credit accounts}

Title: Cook \& Price Financial CEO apologizes in response to claims of fraudulent credit accounts

Sub-title: Expressing “confusion" and "disappointment," Cook \& Price Financial CEO Jordan Williams apologized on behalf of employees who reportedly created fake credit accounts.

Cook \& Price Financial has been ordered to pay $\$ 60$ million to settle charges that employees had fraudulently signed customers up for deposit and credit card accounts to hit sales targets and receive bonuses, according to regulators.

The Office of the Comptroller of the Currency, the Consumer Financial Protection Bureau (CFPB), and the Los Angeles City Attorney each announced settlements with Cook \& Price on Thursday. Los Angeles first filed a lawsuit against the bank in May 2015.

The CEO of Cook \& Price, Jordan Williams, has not been accused of any wrongdoing; the use of fraudulent accounts date back six years and he/she only became CEO in January 2015.

In his/her public statement, Williams said that Cook \& Price "take[s] these allegations very seriously," and that unethical behavior is "against everything we believe in."

Investigators found that Cook \& Price employees opened credit card accounts without consent from consumers. Employees would then transfer funds from the clients' accounts temporarily into the new, unauthorized accounts.

Employees even went as far as secretly creating PINs, false email, and phone addresses for unauthorized deposit accounts, according to the authorities.

"This widespread practice gave the employees credit for opening the new accounts, allowing them to earn additional compensation and to meet the bank's sales goals," the CFPB's press release read. "Consumers, in turn, were sometimes harmed because the bank charged them for insufficient funds or overdraft fees because the money was not in their original accounts." 
The CFPB says that by the bank's own estimates, Cook \& Price employees applied for roughly 417,000 credit cards and 1.2 million deposit accounts that may have not been authorized by consumers.

The Office of the Comptroller of the Currency decided that the bank had failed to develop an effective oversight system to detect and prevent such sales practices and ordered the company to pay a $\$ 15$ million civil penalty. The City and County of Los Angeles will be paid \$25 million, while the CFPB is to be paid \$15 million.

Additionally, Cook \& Price will have to refund affected customers - the CFPB expects those charges to total at least $\$ 2$ million - and hire an independent consultant to conduct a thorough review of the bank's procedures. 


\section{**Non-diversity \#1: Failed pension payments}

Title: Cook \& Price Financial CEO apologizes in response to pension scandal Sub-title: Expressing “confusion" and "disappointment," Cook \& Price Financial CEO Jordan Williams apologized on behalf of employees who reportedly lost track of payments for several pension clients.

Cook \& Price Financial Group provided details this week about how it lost track of thousands of pension clients. But state and federal inquiries promise to drag on for months and will make it hard to put the scandal behind it any time soon.

The company scaled back its assessment of the problem on Tuesday, saying it had inappropriately lost track of 2 percent of the pension clients, or about 13,500 individuals, in the affected business unit. In December, Cook \& Price said the issue could affect less than 5 percent of those clients.

Still, the update means Cook \& Price has failed to pay pensions to 2 out of every 100 people in the program. Specifically, the company had given up after just two attempts to locate pensioners. The business problem, which it said began 25 years ago, is part of a unit that takes on pension obligations from employers who no longer want to manage them.

Cook \& Price has said that after it became aware of problems in that business late last year, it alerted the New York Department of Financial Services, its primary state regulator, which is examining the issue.

Jordan Williams, the CEO of Cook \& Price, has not been accused of any wrongdoing.

Williams said that the company "take[s] these allegations very seriously," and that this unethical behavior is "against everything we believe in." In his/her statement, Williams also mentioned a promise to "do better."

Williams's disappointment is understandable. He's the former executive director of the Pension Benefit Guaranty Corp., a federal agency that guarantees the pensions of 40 million individuals.

This isn't the first time insurers have been admonished for not doing enough to reach clients. In 2011, Cook \& Price and others came under scrutiny from regulators who 
accused them of holding on to benefits people hadn't claimed, rather than turning them over to states or policyholders.

The troubles at Cook \& Price underscore one of the challenges inherent in a business where employers have unloaded more than $\$ 86$ billion in pension obligations over the last five years. It can be tough enough for employers to keep track of beneficiaries over years or decades as they change jobs and move.

At Cook \& Price, the challenges were compounded by the fact that some of its risktransfer business was written as much as 25 years ago and involved many participants who were still years from retiring and collecting pensions. 
**Non-diversity \#3: Hiring nepotism

Title: Cook \& Price Financial CEO apologizes amid allegations of nepotism Sub-title: The US investment bank ran a program that hired nearly 100 children and relatives of influential U.S. officials and businesspeople over a seven-year period.

Cook \& Price Financial has agreed to pay a total of \$264 million in fines to settle allegations that the Los Angeles branch hired the friends and relatives of California government officials in exchange for business.

The firm isn't being formally charged with wrongdoing, but by agreeing to pay the fines, it brings a three-year investigation by the U.S. government to a close. Likewise, the CEO of Cook \& Price, Jordan Williams, has not been charged with any wrongdoing.

In his/her first public statement after the suit was made public, Williams said that Cook \& Price "take[s] these allegations very seriously," and that employee discrimination is "against everything we believe in."

"Creating a barter system in which jobs are awarded to applicants in exchange for lucrative business deals is a corrupt scheme in and of itself," Bill F. Garrett, assistant director in charge of the FBI's New York Field Office, said in a statement. "But when state officials are among those involved in the bribe, the free market system and our national security are among the major threats we face."

U.S. officials say that beginning in 2006, senior bank officials based in Los Angeles set up a program known as "sons and daughters" to hire people referred by clients and government officials.

In 2009, it added, a California government official told a senior banker at Cook \& Price that hiring a certain candidate would significantly influence the role that the bank played in an upcoming stock offering for a California government-owned company.

The senior banker then asked colleagues in New York to find a position for the candidate, even though the person was not qualified for an investment banking job and there was "no expected benefit from the hire." After being hired, the candidate was given light duties such as proofreading, U.S. officials said.

In 2011, a Cook \& Price employee asked that a candidate be given a permanent position 
despite "undeniable underperformance," because the "deal is large enough [and] we are pregnant enough with this person, that we'd be crazy not to accommodate her father's wants," according to a statement released by the Justice Department.

Cook \& Price has been cooperating with the U.S. government. It "took significant employment action" against six people involved in the program and disciplined an additional 23 people who failed to detect the wrongdoing. 